\title{
Critical Strain for Dynamic Recrystallisation. The Particular Case of Steels
}

\author{
Gonzalo Varela-Castro ${ }^{1}$, José-María Cabrera ${ }^{1,2, * \mathbb{D}}$ and José-Manuel Prado ${ }^{1}$ \\ 1 Department of Materials Science and Engineering, Universitat Politècnica de \\ Catalunya-BarcelonaTech (UPC), c/Eduard Maristany 10-4, Edificio I, 08019 Barcelona, Spain; \\ gonzalovarelacastro@gmail.com (G.V.-C.); jm.prado@upc.es (J.-M.P.) \\ 2 Institute of Metallurgy and Materials, Universidad Michoacana de San Nicolás de Hidalgo, Edificio U, \\ Av. Francisco Múgica s/n, CU, 58230 Morelia, Michoacán, Mexico \\ * Correspondence: jose.maria.cabrera@upc.es; Tel.: +34-934011097
}

Received: 24 November 2019; Accepted: 2 January 2020; Published: 16 January 2020

\begin{abstract}
The knowledge of the flow behavior of metallic alloys subjected to hot forming operations has particular interest for metallurgists in the practice of industrial forming processes involving high temperatures (e.g., rolling, forging, and/or extrusion operations). Dynamic recrystallisation (DRX) occurs during high temperature forming over a wide range of metals and alloys, and it is known to be a powerful tool that can be used to control the microstructure and mechanical properties. Therefore, it is important to know, particularly in low stacking fault energy materials, the precise time at which DRX is available to act. Under a constant strain rate condition, and for a given temperature, such a time is defined as a critical strain $\left(\varepsilon_{c}\right)$. Unfortunately, this critical value is not always directly measurable on the flow curve; as a result, different methods have been developed to derive it. Focused on carbon and microalloyed steels subjected to laboratory-scale testing, in the present work, the state of art on the critical strain for the initiation of DRX is reviewed and summarized. A review of the different methods and expressions for assessing the critical strain is also included. The collected data are well suited to feeding constitutive models and computational codes.
\end{abstract}

Keywords: critical strain; onset dynamic recrystallisation; dynamic restoration; softening; hot rolling; strain hardening rate; steels

\section{Introduction}

Recrystallisation during hot working operations of metals and metallic alloys (temperature in the range of $0.5-0.9 \mathrm{~T}_{\mathrm{m}}$, where $\mathrm{T}_{\mathrm{m}}$ is the absolute melting temperature [1-3]) is commonly called dynamic recrystallisation (DRX) or discontinuous dynamic recrystallisation (dDRX) and has been broadly investigated in the past decades. Jonas [4] pointed out that DRX is accepted as one of the most relevant and meaningful mechanisms available for the control of microstructure under industrial operations. DRX is able to cause a great impact on the hot flow behavior, affecting the microstructure and properties of the material after processing. The desired mechanical properties can be achieved by acting on the DRX kinetics [4]. Frequently, the presence of DRX is indicated by a well-defined peak stress value $\left(\sigma_{\mathrm{p}}\right)$ on the experimental true stress-true strain $(\sigma-\varepsilon)$ curves. However, DRX may be initiated at strain values lower than those corresponding to the peak stress [5-7]. DRX can also take place in many metallic alloys, even though no clear peak stress is observed. Ignoring cases of recrystallisation of the multiple peaks type, because of the small interest from an industrial point of view, and under specific deformation conditions, the behavior of low stacking fault energy (SFE) materials differs from that of high SFE materials, and can engender two well-differentiated behaviors and DRX flow curves. In both cases, at low strains, strain hardening and softening by dynamic recovery (DRV) are the deformation 
controlling mechanisms. In high SFE materials, the strain hardening can be compensated by DRV and a steady state in stress is finally attained $\left(\sigma_{\mathrm{sDRV}}\right)$, where DRV is the main restoration process $[1,8]$. This behavior is characterized by a continuous increase in the flow stresses during plastic deformation. The presence of the DRV promotes equilibrium and the rate of strain hardening (SH) progressively decreases with straining and becomes minima at high strains, leading to a steady state stress. This behavior appears and remains just after the maximum stress, as shown in Figure 1.

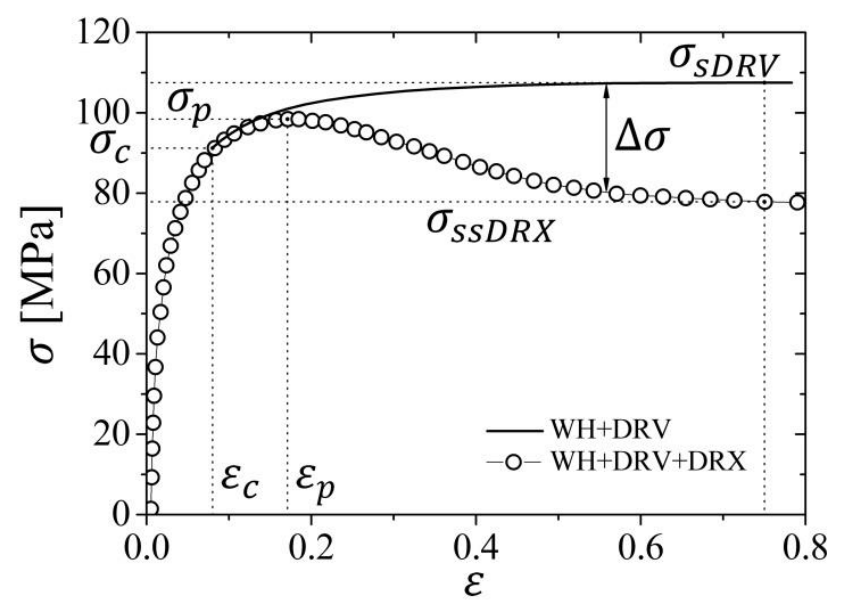

Figure 1. Schematic of hot working compression curves. DRX, dynamic recrystallization; DRV, dynamic recovery; $\mathrm{WH}$, work hardening.

On the other hand, in low SFE materials such as gamma-iron austenite $(\gamma$-Fe), the DRV kinetics is slow, allowing DRX to take place because the large amount of dislocations generated during work hardening is not annihilated. Therefore, it can be assumed that, once a certain critical dislocation density value $\rho_{\mathrm{c}}$ (associated to a critical strain) is reached, DRX is activated as an additional softening mechanism. For a given material, the critical dislocation density depends on the strain rate, temperature, chemical composition, and grain size. Under low strain rate conditions, and when the critical density value is attained, DRX is initiated mainly by the bulging of pre-existing grain boundaries. In the case of high strain rates, DRX is initiated by the growth of high angle boundaries (HAB) formed by dislocation accumulation. As a consequence of this, the local differences in the dislocation density gradient over the grain boundary surrounding area act as the driving force for the nucleation of the new nuclei [9]. Then, this is followed by the long-range migration of HAB. Conventional DRX is considered to be a two-step process governed by the following: (i) nucleation and (ii) grain growth [8]. The flow curve displays a peak in stress, after which stress values gradually decrease until a steady state $\left(\sigma_{\text {ssDRX }}\right)$ is attained. The latter state reflects the dynamic equilibrium between strain hardening and strain softening due to the formation of new grains and the associated grain boundary migration [10]. Consequently, the steady state stress can be achieved both via DRV (high SFE materials) as well as via DRX (moderate to low SFE materials). Gottstein et al. [11] point that the strain is not a state variable of crystal plasticity and therefore, in order to be precise, is more appropriate to talk about critical conditions for microstructural instability rather than to critical strain. As strain itself does not describe the current state of the material but the history of the deformation, often some models formulate the critical strain for DRX in terms of a critical dislocation density or deformation resistance for a given grain size [12].

As mentioned above, DRX is in fact initiated before the strain corresponding to the peak stress. The scientific literature reports that this particular value of strain is linked with the minimum amount of stored energy induced by deformation needed to start DRX $[13,14]$ and is defined as the critical strain for the onset of dynamic recrystallization $\varepsilon_{\mathrm{c}}$, associated with the critical stress $\sigma_{\mathrm{c}}$. Consequently, as already stated, a critical dislocation density value is necessary in order to initiate DRX. Generally, this critical value is related to the nucleation by the formation of mobile high angle boundaries 
simultaneously with the straining conditions. The nucleation of DRX in polycrystals can be originated at high angle boundaries such as original grain boundaries, boundaries of dynamically recrystallised grains, and/or high angle boundaries created during deformation (deformation bands/twins). Bulging and serration of grain boundaries are frequently observed as a prelude to dynamic recrystallization, and it is usually assumed that a mechanism closely related to strain-induced grain boundary migration operates $[1,7,15,16]$. Excellent references regarding nucleation and grain growth mechanisms can be consulted in the article published by Rios et al. [17].

For a single peak behavior (related to grain refinement $[8,18]$ ), nucleation mainly occurs along existing grain boundaries, and this situation is referred to as the so-called necklace microstructure $[8,18,19]$. The growth of each grain is stopped by the concurrent deformation. When all the grain boundary sites are occupied and exhausted, further new grains are nucleated within the primary grains at the interface of the recrystallised and un-recrystallised grains [20-22]. On the other hand, for the multiple peak case, the growth of each new grain is terminated by boundary impingement and not by the concurrent deformation [23].

Wray [13] was the first to highlight that the critical strain corresponds to the application of a minimum amount of energy required to start the DRX. This critical amount of energy reflects the upper limit of energy that can be stored in the material [13]. This value is a necessary condition for starting DRX, but it may not be a sufficient condition. In fact, the initiation of DRX further requires that any counterpart to the energy stored, for example, the energy dissipation rate, also reaches a critical value [14].

For a given material, the characteristics of the dynamic recrystallisation behavior (i.e., the critical strain value) depend mainly on several parameters and factors, namely, the chemical composition of the alloy, the grain size prior to the deformation, the temperature and strain rate, the deformation mode (torsion, compression, etc.), and the applied thermomechanical cycle. The critical strain for the onset of DRX decreases with a decrease in the prior grain size, with a decrease in strain rate, and also with a temperature increase $[1,7,15,24]$. Also, the DRX kinetics is affected by the precipitation of second phases [25]. Accordingly, some significant physical properties of the system change with the temperature and/or strain rate. Two of them are closely related to the initiation of DRX: (i) the driving force for dynamic recrystallisation and (ii) the mobility of the sub-boundaries. The former will decrease with decreasing strain rate or increasing temperature, as the dislocation density generated at any given level of strain will be lower. The mobility of the sub-boundaries (in absence of precipitation or segregated impurities) is a function of the diffusivity, and thus increases with increasing temperature, but it is relatively insensitive to the strain rate. The rest of the properties concern the segregation rate [26].

It can be seen, for example, that the values of the peak strain $\left(\varepsilon_{\mathrm{p}}\right)$ determined in torsion solid samples are higher (by a factor of $\sim 1.3$ to 2.6 ) than the values of the peak strain determined in the compression mode [7,27]. Weiss and colleagues [27] have affirmed that the measurement of the peak strain and the recrystallisation strain $\left(\varepsilon_{x}\right)$ by different testing methods led to conflicting results because of the different contributions of friction, texture change, slip geometry, adiabatic heating, and localization for each technique, as shown in Figure 2. For a single peak DRX behavior, Weiss et al. [27] represented the recrystallisation strain $\varepsilon_{\mathrm{x}}$ as the additional strain to $\varepsilon_{\mathrm{p}}$ required to reach the steady state regime. In the case of multiple peaks DRX behavior, $\varepsilon_{\mathrm{X}}$ was defined as the additional strain to $\varepsilon_{\mathrm{p}}$ that is required to reach the strain value corresponding to the minimum stress value of the first cycle of DRX. This concept is slightly similar to the original analysis published by Luton and Sellars [5], based on the mechanical aspects of dynamic recrystallization, and where $\varepsilon_{\mathrm{x}}$ represents the additional strain to $\varepsilon_{\mathrm{c}}$, required to reach the steady state regime. 

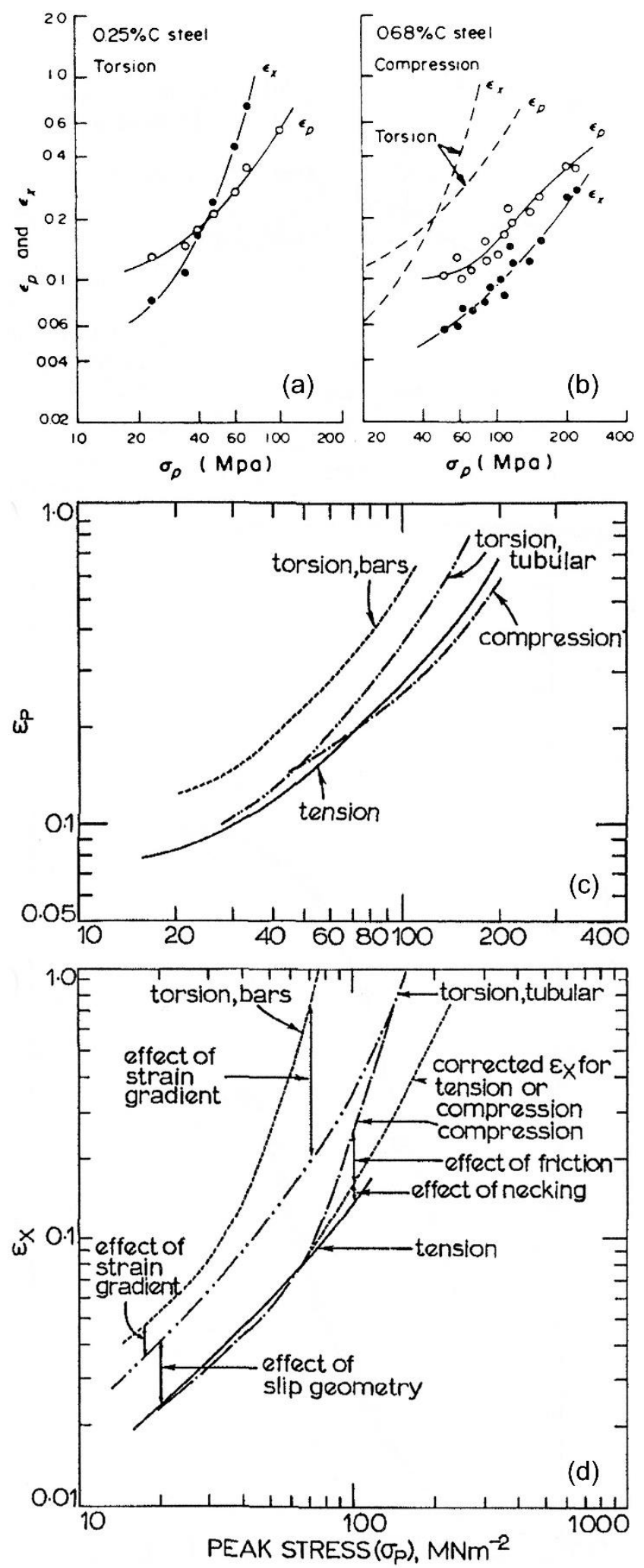

Figure 2. $(\mathbf{a}, \mathbf{b})$ Effect of test type on $\varepsilon_{\mathrm{p}}$ and $\varepsilon_{\mathrm{x}}$ for plain $\mathrm{C}$ steels. (c) Same than $(\mathbf{a}, \mathbf{b})$ but including tubular torsion and tensile tests. (d) Effect of other artifacts such as necking, strain gradient, and so on, on $\varepsilon_{\mathrm{X}}[(\mathbf{a}, \mathbf{b})$ reprinted from ref. [7] and (c,d) from ref. [27] with permission from Elsevier and Taylor \& Francis respectively. 
Also, the initial grain size has a notorious influence on the DRX kinetics and microstructure owing to changes in the grain-boundary surface area conditions, thus affecting the nucleation kinetics. The finer the microstructure (initial grain size), the lower the critical and peak strains. Dislocations can accumulate more rapidly in a microstructure having a minor grain size; therefore, a higher specific grain boundary area-volume ratio promotes faster DRX kinetics. A decrease in the initial grain size can accelerate the onset of the DRX, increase the DRX kinetics, and also affect the microstructural and mechanical properties of the deformed structure $[7,10]$.

The value of the critical strain for the onset of DRX is an important parameter employed in the mathematical modeling of the microstructural evolution during rolling, forging, or extrusion loads in metallic alloys. Knowledge of the aforementioned critical strain is a requirement for the prediction of the operating softening mechanisms in hot working processes [28]. Moreover, understanding the behavior of alloys subjected to hot forming operations is essential for industrial engineering and designers [29]. Valuable information for modeling features of these processes such as the kinetics of transformations, mechanical properties, or microstructure evolution, among others, can be obtained.

After the introduction, this paper is organized as follows. In Section 2, a resume of the main different alternative ways to determine the critical strain for the initiation of DRX is conducted. Subsequently, an extended collection of experimental data (approximately 320 experimental values) regarding the peak strain exponent ( $m$; see Equations (1a) and (1b)), mainly associated to the strain rate through the Zener-Hollomon parameter [30], is presented in Section 3. Also, in Section 3, an analysis of the collected and reviewed experimental data of the peak strain and/or the critical strain exponent $\mathrm{m}$, as a function of the carbon equivalent content $\left(\mathrm{C}_{\mathrm{eq}}\right)$ of the alloy, is performed. These data are collected and listed in Appendix A. Finally, the conclusions of this study are presented in Section 4. In order to facilitate the easy following of the large number of equations a list of symbols is offered in Abbreviations. This literature review article is an extension of work previously conducted by Varela-Castro et al. [31].

\section{Literature Review}

The onset of DRX is truly dynamic and cannot be easily extracted from the stress-strain curves. Then, and for simplicity, some authors state that the value of deformation needed to start DRX is proportional to the peak strain $\varepsilon_{\mathrm{p}}$ [32]; $\varepsilon_{\mathrm{c}}=\mathrm{a} \varepsilon_{\mathrm{p}}$, where a is a coefficient of proportionality. In this regard, it should be mentioned that, usually, the peak strain and the critical strain for dynamic recrystallisation are related by a factor ranging between 0.5 and 0.90 , with 0.8 being the most commonly reported value for C-Mn steels [33]. Here, this factor is defined as the critical ratio of strains $R_{\varepsilon}=\frac{\varepsilon_{c}}{\varepsilon_{\mathrm{p}}}$. There are several facts that can explain the relative scatter observed in the literature for $R_{\mathcal{E}}$. Apart from a possible dependence of this relationship on a given material, the test method employed can significantly affect the measurement of $\varepsilon_{\mathrm{c}}$ [27].

As already stated, the obtaining of the strain associated to the DRX initiation may be difficult, and several evaluation methods have been proposed. Generally, it is possible to differentiate in the literature four different ways to determine the critical strain for the onset of DRX, namely, (i) through metallographic determination, (ii) by using analytical expressions for $\varepsilon_{\mathfrak{c}}$ or $\varepsilon_{\mathrm{p}}$ (assuming $\mathrm{R}_{\varepsilon}$ ), (iii) by applying methods to calculate the critical strain $\varepsilon_{\mathrm{c}}$ for DRX, and (iv) by direct calculation of the critical strain ratio applying analysis of constitutive models as well as through application of constitutive physically-based models to derive the DRX nucleation. In the forthcoming paragraphs, details of each category are provided. The collected data (see Table A1 in Appendix A) comprise valuable data obtained from plain carbon steels, microalloyed steels, stainless steels, and high-alloy steels (e.g., transformation induced plasticity (TRIP) and twinning-induced plasticity steels (TWIP) steels) reported in the scientific literature. The consulted bibliography includes compression, torsion, tensile, and rolling testing data. 


\subsection{Metallographic Determination}

The determination of the critical strain for initiation of DRX through metallography and metallographic observation techniques involves a pronounced effort on the implementation of an extensive number of tests, sample preparation, and examination. This may be a very time-consuming task. Several authors have shown the microstructure evolution during hot deformation from critical to steady state conditions. Moreover, depending on the facilities, post-dynamic phenomena can occasionally occur and, in addition to the instability of austenite at room temperature, the detection of the initiation of DRX can be not accurate enough by employing classical metallography. Additionally, cooling from hot working temperature during quenching can promote phase changes that can alter the deformed microstructure, which in turn adds difficulty to the metallographic analysis. In the following, some examples are cited.

Luton and Sellars [5], working with pure $\mathrm{Ni}$ and $\mathrm{Ni}-\mathrm{Fe}$ alloys tested in torsion at approximately $1033 \mathrm{~K}\left(760^{\circ} \mathrm{C}\right)$ to $1553 \mathrm{~K}\left(1280^{\circ} \mathrm{C}\right)$ and $2.0 \times 10^{-3}$ to $4.0 \mathrm{~s}^{-1}$, have evidenced through metallographic observation that new recrystallised grains appear when the peak stress had been attained. It is reasonable to assume that the strain value associated to the peak stress was closely related to the critical strain for dynamic recrystallisation [5,34]. Glover and Sellars [35], in torsion of ferrite tested at $773 \mathrm{~K}\left(500{ }^{\circ} \mathrm{C}\right)$ to $1073 \mathrm{~K}\left(800{ }^{\circ} \mathrm{C}\right)$ and $3.8 \times 10^{-4}$ to $6.4 \mathrm{~s}^{-1}$, have argued that, when DRX takes place, the critical strain for the onset of dynamic recrystallisation is the most important parameter in determining the flow stress. Also, Glover and Sellars [35] have remarked that the values of critical strain for DRX lie systematically below the measured values of the strain associated to the peak strain. Sah and colleagues [20] studied the effect of the initial grain size of pure nickel under hot torsion and revealed via metallography that, before the peak torque is reached, a well-developed dynamically recrystallised microstructure was formed. Also, they showed that, when grain size decreases, the rate of recrystallisation increases markedly and is accompanied by a decrease in the critical strain for DRX. Meanwhile, Ouchi and Okita [22], working on high strength low alloy and stainless steels under hot compression testing $\left(5.0 \times 10^{-4}-10.0 \mathrm{~s}^{-1}\right.$ and $\left.1173 \mathrm{~K}\left(900^{\circ} \mathrm{C}\right)-1473 \mathrm{~K}\left(1200{ }^{\circ} \mathrm{C}\right)\right)$, developed a rapid cooling system to investigate the microstructural changes associated with DRX in order to avoid static recovery and recrystallisation. Metallographic examination revealed that dynamic recrystallisation started at a fraction of approximately 0.8 of the peak strain, originated by local bulging of grain boundaries. A similar study was performed by Maki and colleagues [36,37]. These authors analyzed the DRX behavior of austenite in an 18-8 stainless steel and an 18 Ni maraging steel by microstructural observations of the water-quenched specimens deformed under tensile deformation, applying different strain rates and temperatures, ranging from $1073 \mathrm{~K}\left(800^{\circ} \mathrm{C}\right)$ to $1473 \mathrm{~K}\left(1200^{\circ} \mathrm{C}\right)$ and from $1.0 \times 10^{-3}$ to $1.0 \times 10^{-1} \mathrm{~s}^{-1}$, respectively. They identified the critical strain value for the occurrence of dynamic recrystallisation from the tensile hot flow curve using optical micrographs showing the progress of DRX of austenite with strain.

Additionally, the work published by Ueki et al. [38] was conducted in order to clarify the behavior of DRX in non-ferrous metals and alloys on the basis of the results obtained from mechanical tests and microstructural observations. The investigators critically discussed the factors that influence the occurrence of DRX and proposed a new way of classifying the operative dynamic restoration processes. They examined the high-temperature mechanical behavior of $\mathrm{Cu}, \mathrm{Cu}-\mathrm{Al}$ alloys, and $\mathrm{Ni}$ using torsional testing with hollow samples in conjunction with microstructural observations on deformed and quenched specimens using both optical and transmission electron microscopy (TEM).

More recently, Dehghan-Manshadi et al. [39,40], under torsion experiments, investigated the hot deformation behavior of an austenitic stainless steel (AISI 304) in order to characterize the evolution of the dynamically recrystallised structure at temperatures and strain rates in the domain of $1123 \mathrm{~K}\left(850^{\circ} \mathrm{C}\right)$ to $1373 \mathrm{~K}\left(1100^{\circ} \mathrm{C}\right)$ and $1.0 \times 10^{-3}$ to $1.0 \mathrm{~s}^{-1}$, respectively [39]. The authors used common sample metallographic preparation and electron backscattered diffraction (EBSD) techniques to analyze the evolution of the microstructures during hot deformation from the critical to steady state. Furthermore, the rate (slope) of the work hardening rate curves was used to identify the critical strain for the initiation 
of DRX by applying the mathematical approach proposed by Poliak and Jonas [14,29], as explained later in Section 2.4. For example, at $1173 \mathrm{~K}\left(900^{\circ} \mathrm{C}\right)$ and $1.0 \times 10^{-2} \mathrm{~s}^{-1}$ and at strain of 0.4 , Dehghan-Manshadi et al. [39] showed that formation of new grains can occur, even at lower strains than the critical strain predicted ( 0.45). Also, microstructural analysis indicated that DRX was operative over an extensive domain of deformation conditions even when the curves showed continuous work hardening behavior. A similar analysis was previously reported by Stewart et al. [41], where a kinetic model of DRX for an austenitic stainless steel and a hypereutectoid plain carbon steel was derived using compression testing over the range of $1173 \mathrm{~K}\left(900^{\circ} \mathrm{C}\right)$ to $1373 \mathrm{~K}\left(1100^{\circ} \mathrm{C}\right)$ (at a constant strain rate of $1.0 \times 10^{-1} \mathrm{~s}^{-1}$ ) and electron backscatter diffraction. This technique allowed faster and more accurate measurement of the grain size and recrystallised fraction, as well as the corroboration of the critical strain for initiation of DRX and the strain to achieve maximum softening. Beladi and co-workers [42], using hot torsion tests, also reported a similar approach for an Ni-30\% Fe alloy.

\subsection{Analytical Expressions for $\varepsilon_{c}$ or $\varepsilon_{p}$}

Perhaps the easiest way to determine the critical strain $\varepsilon_{\mathrm{c}}$ for a given material is through the assumption of a critical strain ratio and to derive the critical strain through an analytical expression for the peak stress as a function of testing conditions and microstructure. To organize and facilitate the understanding of the present paper, all the following expressions are cited in a general way, so in some cases, the name of the parameters are not exactly the same as those reported by the authors. Equation (1a), suggested by Sellars [33], represents one of the most commonly and widely reported empirical relationships for the determination of the peak strain as a function of the thermomechanical variables. In addition, in the following paragraphs, a certain number of relationships suggested in the scientific literature will be described with respect to their ability to approximate experimental data. Almost $90 \%$ of the published data in Table 1 correspond to the following power law (see Equations (1a) and $(1 b))$ :

$$
\begin{gathered}
\varepsilon_{\mathrm{p}}=\mathrm{kd}_{0}^{\mathrm{n}} \mathrm{Z}^{\mathrm{m}} \\
\varepsilon_{\mathrm{p}}=\mathrm{K} \mathrm{Z}^{\mathrm{m}}
\end{gathered}
$$

where $\mathrm{k}, \mathrm{K}$, n (usually equal to 0.5 [33]), and $\mathrm{m}$ are material dependent constants; $\mathrm{d}_{0}$ is the initial grain size; and $\mathrm{Z}$ is the Zener-Hollomon parameter $\left(\mathrm{s}^{-1}\right)$ [30], defined as follows:

$$
\mathrm{Z}=\dot{\varepsilon} \exp \left(\frac{\mathrm{Q}_{\mathrm{hw}}}{\mathrm{RT}}\right),
$$

where $\dot{\varepsilon}$ is the strain rate $\left(\mathrm{s}^{-1}\right), \mathrm{Q}_{\mathrm{hw}}$ is the activation energy for hot deformation $\left(\mathrm{J} \cdot \mathrm{mol}^{-1}\right)$, R is the universal gas constant $\left(\mathrm{J} \cdot \mathrm{mol}^{-1} \cdot \mathrm{K}^{-1}\right)$, and $\mathrm{T}$ is the absolute temperature $(\mathrm{K})$. All cases where $\mathrm{kd} \mathrm{d}_{0}^{\mathrm{n}}=\mathrm{K}$ will be referenced using the equation number without distinction between the types (a) or (b). In those cases where the initial grain size is kept constant, Equation (1a) can be simplified into Equation (1b) [43]. These expressions have been developed empirically and take into account the influence of the initial microstructure, through the grain size prior to deformation $\mathrm{d}_{0}$, and the deformation conditions through the Zener-Hollomon parameter Z.

Mintz et al. [44,45], working with C-Mn and C-Mn-Al steels and studying the influence of DRX on the tensile ductility at high temperature in the range of $973 \mathrm{~K}\left(700^{\circ} \mathrm{C}\right)$ to $1423 \mathrm{~K}\left(1200{ }^{\circ} \mathrm{C}\right)$ and strain rates ranging between $3.0 \times 10^{-4}$ and $3.0 \times 10^{-2} \mathrm{~s}^{-1}$, proposed the following empirical relation in order to take into account the effect of the initial grain size on the constant factor K from Equation (1b):

$$
\varepsilon_{\mathrm{p}}=\left(\mathrm{k}_{1} \mathrm{~d}_{0}^{1 / 2}+\mathrm{k}_{2} \mathrm{~d}_{0}^{-1 / 2}\right) \mathrm{Z}^{\mathrm{m}}
$$

where $\mathrm{k}_{1}$ and $\mathrm{k}_{2}$ are numerical constants. Grain size is an important factor controlling the peak strain, because it defines the number of nucleation sites for DRX. Equation (3) indicates that, for finer grain sizes, DRX is more readily attained than would be predicted by a simple $\mathrm{d}_{0}^{1 / 2}$ relationship $[44,45]$. 
Table 1. Statistic indicators of the reviewed data.

\begin{tabular}{cccc}
\hline & \multicolumn{3}{c}{ Parameter } \\
\hline Statistic Indicator & $\boldsymbol{m}$ & $\boldsymbol{Q}_{h w}$ & $\boldsymbol{R}_{\boldsymbol{\varepsilon}}$ \\
\hline Number of data & 318 & 303 & 216 \\
Mean & 0.152 & 347 & 0.71 \\
Standard deviation & 0.07 & 81.15 & 0.16 \\
Geometric mean & 0.136 & 338 & 0.69 \\
Mode & 0.150 & 270 & 0.80 \\
Median & 0.150 & 332 & 0.72 \\
Minimum & 0.008 & 129 & 0.12 \\
Maximum & 0.678 & 747 & 1.00 \\
\hline$Q_{h w}:\left[\mathrm{kJ} \cdot \mathrm{mol}^{-1}\right]$ & & &
\end{tabular}

Medina et al. [46-49], working with microalloyed steels, proposed a modified relationship for the peak strain, as shown in Equation (4a). They discussed that, under hot working conditions, the $\mathrm{Z}$ parameter appears to be insufficient to describe with accuracy the dependence of peak strain on the strain rate and temperature. Therefore, Medina and Hernandez [47] included in their model a parameter named $\mathrm{A}\left(\mathrm{s}^{-1}\right)$, which depends on both the chemical composition and the activation energy.

Studying the dynamic recrystallisation of an AISI 304 stainless steel through torsion test in the temperature range of $1173 \mathrm{~K}\left(900^{\circ} \mathrm{C}\right)-1373 \mathrm{~K}\left(1100{ }^{\circ} \mathrm{C}\right)$ and the strain rate range of $5.0 \times 10^{-2}-5.0 \mathrm{~s}^{-1}$, Kim and Yoo [50] reported similar relationships for $\varepsilon_{p}$ and $\varepsilon_{\mathrm{c}}$. See Equations (4a) and (4b).

$$
\begin{gathered}
\varepsilon_{\mathrm{p}}=\mathrm{kd}_{0}^{\mathrm{n}}\left(\frac{\mathrm{Z}}{\mathrm{A}}\right)^{\mathrm{m}} \\
\varepsilon_{\mathrm{p}}=\mathrm{K}\left(\frac{\mathrm{Z}}{\mathrm{A}}\right)^{\mathrm{m}} .
\end{gathered}
$$

Kowalski et al. [51] reported, for plane strain compression testing of ultra-low $C$ steels, that the critical strain for the onset of DRX $\varepsilon_{\mathrm{c}}$ is a function of the Zener-Hollomon parameter normalized by the square of the steady state flow stress arising from the balance between work hardening and DRV $\left(\sigma_{\mathrm{sDRV}}\right)$, as shown in Equation (5):

$$
\varepsilon_{\mathrm{c}}=\mathrm{K}\left(\frac{\mathrm{Z}}{\sigma_{\mathrm{sDRV}}^{2}}\right)^{\mathrm{m}} \text {. }
$$

Several publications [28,52-56], mainly dealing with microalloyed steels, reported some empirical formulations that include a corrective factor $(\mathcal{F})$, which depends on the chemical composition, as shown by Equation (6):

$$
\varepsilon_{\mathrm{p}}=\mathrm{k} \mathcal{F} \mathrm{d}_{0}^{\mathrm{n}} \mathrm{Z}^{\mathrm{m}}
$$

Minami et al. [52] proposed a value of the parameter $\mathcal{F}$ equal to $\frac{1+20 \% \mathrm{Nb}}{1.78}$, for $\mathrm{Nb}$ steels $(0.020-0.080 \% \mathrm{Nb})$ tested under torsion. Fernández et al. [53] investigated the dynamic recrystallisation behavior of $\mathrm{Nb}$ and $\mathrm{Nb}-\mathrm{Ti}$ microalloyed steels using torsion tests in the temperature range between $1273 \mathrm{~K}\left(1000{ }^{\circ} \mathrm{C}\right)$ and $1473 \mathrm{~K}\left(1200{ }^{\circ} \mathrm{C}\right)$ and the strain rate range between $2.0 \times 10^{-2}$ and $5.0 \mathrm{~s}^{-1}$. They proposed a relationship to predict the peak strain for both steels by quantifying the retardation of the DRX produced by the increase of the microalloying elements in solid solution ( $\mathrm{Nb}$ and $\mathrm{Ti})$ as the reheating temperature increases, applying the following corrective factor: $\frac{1+20(\% \mathrm{Nb}+0.02 \% \mathrm{Ti})}{1.78}$. In an analogous way, Elwazri and colleagues [54], studying under torsion hypereutectoid steels $(1.0 \% \mathrm{C})$ alloyed with high silicon and microalloying levels of vanadium, found that the constant $\mathrm{k}$ showed a relationship with the vanadium content that can be expressed as follows: $1.479 \ln [\mathrm{V}]+11.782$. As an extension of the early work of Fernández et al. [53], Pereda et al. [55] analysed the influence of the Mo addition on the dynamic recrystallisation behavior of $\mathrm{Nb}$ microalloyed steels. These latter authors claimed that Mo has a strong solute drag effect, both on the austenite grain size coarsening 
behavior and on the DRX kinetics. However, this effect seems to be independent of the Mo content, at least in the range analyzed. A constant corrective factor to quantify the retardation produced by Mo in solid solution, independent of Mo content, was applied to extend the validity of the pre-existing equation [53]: $\frac{1+20(\% \mathrm{Nb}+0.02 \% \mathrm{Ti}+\Delta 0.035)}{1.78}$; where $\Delta$ is equal to 0 for $\mathrm{Nb}$ and $\mathrm{Nb}-\mathrm{Ti}$ steels, and $\Delta$ is equal to 1 for $\mathrm{Nb}$-Mo steels.

On the basis of previous work and dealing with high temperature performance steels, Zhu and Subramanian [57], in order to obtain a homogeneous distribution of ultrafine grain size in strip finish rolling processes, have stated that the critical strain for initiation of the DRX is given by Equations (7a) and $(7 \mathrm{~b})$ :

$$
\begin{gathered}
\varepsilon_{\mathrm{c}}=\mathrm{d}_{0}^{\mathrm{n}}(\mathrm{m} \ln \mathrm{Z}+\mathrm{a}) \\
\varepsilon_{\mathrm{c}}=\mathrm{m} \ln \mathrm{Z}+\mathrm{a},
\end{gathered}
$$

where the constants $\mathrm{m}$ and a took the values of 0.0299 and -0.598 , respectively.

San Martín et al. [58,59] on C-steels modified the classical equation for the peak strain, taking into account the influence of the activation energy $Q_{h w}$ for hot working, as shown in Equation (8). In this case, the authors reported an average value of -2.63 for the parameter a, for carbon contents from $0.16 \%$ to $1.06 \%$.

$$
\varepsilon_{\mathrm{p}}=\mathrm{kd}_{0}^{\mathrm{n}} \mathrm{Z}^{\mathrm{m}} \mathrm{Q}_{\mathrm{hw}}{ }^{\mathrm{a}} \text {. }
$$

Kuc et al. [60], applying extensive stereological analysis, reported an expression that included a quantitative description of the shape and size of the grains. A strong influence of the average grain size on the peak stress was observed and led to Equations (9a) and (9b):

$$
\begin{gathered}
\varepsilon_{\mathrm{p}}=\mathrm{kA}_{0}^{\mathrm{a}} \mathrm{Z}^{\mathrm{m}} \\
\varepsilon_{\mathrm{p}}=\mathrm{kV}_{0}^{\mathrm{b}} \mathrm{v}\left(\mathrm{V}_{0}\right)^{\mathrm{c}} \mathrm{Z}^{\mathrm{m}},
\end{gathered}
$$

where $A_{0}, V_{0}$, and $v\left(V_{0}\right)$ are the mean area of the initial grain plane section expressed in $\mu m^{2}$, the mean grain volume expressed in $\mu \mathrm{m}^{3}$, and the variability factor of the grain volume expressed in percentage, respectively. Kuc et al. [60] also described the dependencies between peak strain $\varepsilon_{\mathrm{p}}$ and the initial grain size and Zener-Hollomon parameter for $\mathrm{Cr}-\mathrm{Mn}$ and $\mathrm{Cr}-\mathrm{Ni}$ austenitic steels tested using a torsion plastometer. In this occasion, the authors reported values for the constants $a, b$, and c of $0.14,0.08$, and 0.31 , respectively.

Some authors report that the critical strain for dynamic recrystallisation can be expressed also as a double function of the strain rate and strain itself, as shown in Equation (10). In this sense, Panigrahi [61], reviewing the thermomechanical processing of low carbon steel plate and hot strip, and reported a value of -0.071 for the exponent $\mathrm{m}^{\prime}$.

$$
\varepsilon_{\mathrm{c}}=\mathrm{kd}_{0}^{\mathrm{n}} \dot{\varepsilon}^{\mathrm{m}^{\prime}} \mathrm{Z}^{\mathrm{m}}
$$

In order to describe the relationship between the peak or critical strain with the hot working conditions, some authors have published several mathematically equivalent expressions to Equations (1a) and (1b) [62-67]. However, in certain cases, the values of the activation energy used for the calculation of the Zener-Hollomon parameter Z (Equation (2)) do not match with the value used in the equation that represents $\varepsilon_{\mathrm{p}}$ or $\varepsilon_{\mathrm{c}}$, such as Equation (11b). Equations (11a) and (11b) show some examples of these expressions, where the use or not of the $\mathrm{R}$ constant and/or the use of a constant prior austenite grain size can be noted. Solhjoo [68], on the basis of the model proposed by Lin et al. [69] and Mandal et al. [70], modified the $Z$ parameter $\left(Z_{m}=\dot{\varepsilon}^{m^{\prime}} Z\right.$, where $m^{\prime}$ is a constant equal to $\left.\frac{4}{3}\right)$ in order to improve the accuracy of the estimations of $\varepsilon_{\mathrm{p}}$, as shown in Equation (12), where a is a constant and is found to be 0.26 for AISI 304 stainless steels. In other cases, in which the prior austenite grain size is kept constant, and derivation of its effect or influence cannot be obtained or expected, another type of equation has been proposed. While several authors claim that the critical strain for the 
onset of DRX is also dependent on strain rate and increases according to the increase in strain rate, Senuma et al. [71], studying the recrystallisation behavior of carbon steels $(0.08 \mathrm{wt}$. \%C $-0.81 \mathrm{wt}$. \%C), reported that $\varepsilon_{\mathrm{c}}$ is a solely function of the temperature, as shown in Equation (13b), where the value of the constants $\mathrm{K}$ and $\mathrm{b}$ are equal to $4.8 \times 10^{-4}$ and $8000 \mathrm{~K}\left(7727^{\circ} \mathrm{C}\right)$, respectively. Similar results are reported by Anan et al. [72]. Namba et al. [73], for carbon steels $(0.11 \% \mathrm{C}-0.17 \% \mathrm{C})$, reported $\mathrm{K}$ and $\mathrm{b}$ equal $1.3 \times 10^{-5}$ and $11500 \mathrm{~K}\left(11227^{\circ} \mathrm{C}\right)$, respectively, in order to predict the austenite microstructure during hot rolling.

$$
\begin{gathered}
\varepsilon_{\mathrm{p}}=\mathrm{kd}_{0}^{\mathrm{n}} \dot{\varepsilon}^{\mathrm{m}} \exp \left(\frac{\mathrm{a}}{\mathrm{RT}}\right) \\
\varepsilon_{\mathrm{p}}=\mathrm{kd}_{0}^{\mathrm{n}} \dot{\varepsilon}^{\mathrm{m}} \exp \left(\frac{\mathrm{b}}{\mathrm{T}}\right), \\
\varepsilon_{\mathrm{p}}=\mathrm{K}\left(\dot{\varepsilon}^{1+\mathrm{a}} \exp \left(\frac{\mathrm{Q}_{\mathrm{h} w}}{\mathrm{RT}}\right)\right)^{\mathrm{m}}, \\
\varepsilon_{\mathrm{c}}=\mathrm{K} \exp \left(\frac{\mathrm{a}}{\mathrm{RT}}\right) \\
\varepsilon_{\mathrm{c}}=\mathrm{K} \exp \left(\frac{\mathrm{b}}{\mathrm{T}}\right),
\end{gathered}
$$

where $\mathrm{a}$ and $\mathrm{b}$ are constants. Henceforth, in cases where $\mathrm{kd}_{0}^{\mathrm{n}}=\mathrm{K}$ and/or $\frac{\mathrm{a}}{\mathrm{RT}}=\frac{\mathrm{b}}{\mathrm{T}}$, with $\mathrm{b}=\frac{\mathrm{a}}{\mathrm{R}}$, will be referenced using the equation number without distinction between the types (a) or (b).

Studying the flow behavior under compression of a $\mathrm{Nb}-\mathrm{V}$ high-strength low-alloy (HSLA) steel $(0.13 \% \mathrm{C}, 1.55 \% \mathrm{Mn}, 0.028 \% \mathrm{Nb}, 0.059 \% \mathrm{~V})$ in the range temperature of $1173 \mathrm{~K}\left(900{ }^{\circ} \mathrm{C}\right)$ to $1248 \mathrm{~K}\left(975{ }^{\circ} \mathrm{C}\right)$ and strain rates ranging between $5.0 \times 10^{-3}$ to $5.0 \mathrm{~s}^{-1}$, Wang and Lenard [74] reported the following expression for the peak strain:

$$
\varepsilon_{\mathrm{p}}=\mathrm{K} \dot{\varepsilon}^{\left(\mathrm{a}+\mathrm{b} \frac{\mathrm{Q}_{\mathrm{hW}}}{\mathrm{RT}}\right)},
$$

where $\mathrm{K}, \mathrm{a}$, and $\mathrm{b}$ are numerical constants. Multi-variable non-linear regression analysis of the data permits the derivation of the constitutive relations with values of $\mathrm{K}, \mathrm{a}, \mathrm{b}$, and $\mathrm{Q}_{\mathrm{hw}}$ of $4.6 \times 10^{-1}, 0.542$, -0.0087 , and $464 \mathrm{~J} \cdot \mathrm{mol}^{-1}$, respectively, obtained with a correlation coefficient of 0.99 .

Yang et al. [75] working with a modified CNS-II F/M steel, designed for in-core components of supercritical water cooled reactor, report another different expression for $\varepsilon_{\mathrm{p}}$ :

$$
\varepsilon_{\mathrm{p}}=\mathrm{K} \mathrm{Z}^{\mathrm{m}}+\mathrm{a}
$$

The hot flow behavior of the CNS-II F/M steel was investigated through isothermal hot compression tests at a temperature ranging from $1223 \mathrm{~K}\left(950{ }^{\circ} \mathrm{C}\right)$ to $1373 \mathrm{~K}\left(1100{ }^{\circ} \mathrm{C}\right)$ and strain rate ranging between $1.0 \times 10^{-3}$ and $10.0 \mathrm{~s}^{-1}$. Through regression analysis, Yang et al. [75] show that a is a numerical constant, equal to 0.238 .

On the other hand, Cingara and McQueen [76], McQueen et al. [77,78], and Evangelista et al. [79], among others, published a linear relationship between the peak strain and peak stress according to Equation (16):

$$
\varepsilon_{\mathrm{p}}=\mathrm{a}+\mathrm{b} \sigma_{\mathrm{p}}
$$

In this regard, the formers authors, working with 300 austenitic stainless type steels (torsion tests at $1173 \mathrm{~K}\left(900^{\circ} \mathrm{C}\right)-1473 \mathrm{~K}\left(1200{ }^{\circ} \mathrm{C}\right)$ and $\left.0.1-5.0 \mathrm{~s}^{-1}\right)$, have reported values of a ranging between 0.23 and 0.39 and values of $\mathrm{b}$ in the range of $0.0022-0.0033 \mathrm{MPa}^{-1}$, respectively. Evangelista et al. [79], simulating the rolling schedule of a $41 \mathrm{Cr} 4$ steel by means of torsion tests at temperatures in the interval of $1123 \mathrm{~K}\left(850{ }^{\circ} \mathrm{C}\right)$ and $1323 \mathrm{~K}\left(1050{ }^{\circ} \mathrm{C}\right)$ and equivalent strain rates ranging between 0.05 and $5.0 \mathrm{~s}^{-1}$, reported similar values of $\mathrm{a}$ and $\mathrm{b}\left(\sim 0.11\right.$ and $0.0025 \mathrm{MPa}^{-1}$, respectively). McQueen and Ryan [78] also reported some values of $\mathrm{a}$ and $\mathrm{b}$ for HSLA steels analyzed in austenitic state. 
Furthermore, a number of authors have developed mathematical equations for the beginning of DRX using a formulation based on the nucleation mechanisms of static recrystallization (SRX) [80-82]. Barnett et al. $[83,84]$ affirm that these models fit the observed trends in DRX quite well, however, these models lack firm conclusions to be drawn in order to describe the relative kinetics of the two processes. Barnett et al. $[83,84]$ use conventional equations for the kinetics of SRX and modified them to allow SRX to begin prior to the end of deformation. A general relationship between the kinetics of dynamic and static recrystallisation was developed as follows:

$$
\varepsilon_{\mathrm{c}}=\left[\mathrm{a}(\mathrm{b}+1) \dot{\varepsilon} \mathrm{c}^{\frac{1}{n}}\right]^{\frac{1}{\mathrm{~b}+1}}
$$

where $\mathrm{a}, \mathrm{b}\left(<0\right.$, related to the time taken after deformation for $50.0 \%$ recrystallisation $\left.\mathrm{t}_{0.5}\right)$, and $\mathrm{c}$ (equal to 0.0145 ) are constants; and $\mathrm{n}$ is the Avrami exponent [85-88].

\subsection{Methods to Calculate $\varepsilon_{\mathcal{c}}$}

As already mentioned, several researchers have been studying the modeling of dynamic recrystallisation kinetics in order to predict the flow stress behavior and the microstructural changes associated. Nonetheless, owing to the complexity of the challenge (e.g., dislocation and microstructure evolution, nucleation, growth and impingement of new grains), few approaches successfully correlate the metallurgical principles of dynamic recrystallisation and behaviors.

Luton and Sellars [5] have suggested a critical strain approach to predict the flow stress behavior in terms of the incubation strain $\varepsilon_{\mathrm{c}}$ for the onset of DRX and the strain required for a complete DRX cycle, $\varepsilon_{\mathrm{x}}$. This model, principally concerned with the mechanical aspects of dynamic recrystallisation, provided a significant advance in understanding the DRX phenomena. However, it does not involve the metallurgical principles of DRX and some limitations are presents. The most important one is the indefinite alternation of recrystallisation and hardening cycles [7]. In order to overcome some of the aforementioned limitations, Sah and co-workers $[9,20]$ refined the original model to take into account the influence of grain size changes on the recrystallisation kinetics and explained the damping of the flow stress oscillations at high strains.

One of the most recognized and realistic models that address the nucleation for the onset of DRX was proposed in 1978 by Roberts and Ahlblom [81] on the basis of the model previously reported by Sandström and Lagneborg [80]. The substance of this treatment is that the reduced driving force (i.e., the stored energy difference) modifies the normal energy balance, defining the conditions for nucleation of new grains and the kinetics of nucleation. These depend on the energy of the grain boundaries and on the dislocation density difference between the new recrystallised grains and the matrix [81]. Nucleation is usually promoted by localized strain-induced grain boundary migration, and once the critical dislocation density (associated to the critical strain) is attained, the balance between driving force and surface energy is such that the largest of the bulges can grow with a continuous loss of free energy, and the recrystallisation reaction commences. The recrystallisation reaction continues until the sites at the initial grain boundaries are exhausted. Subsequently, the reaction proceeds via nucleation at the interface between unrecrystallised and recrystallised material until the regions of the latter, emanating from opposing grain boundaries, impinging at the centers of the pre-existing grains. This condition corresponds to the attainment of the steady state on the true stress-strain curve [21]. The model considers the effect of grain size changes, but is limited to the case of grain refinement and single peak flow behavior. This approach, applied to conditions of current deformation, is based upon the classical nucleation theory [89] and describes the strain hardening and dynamic recovery phenomena considering the evolution of the global dislocation density $\rho$, that is, neglecting the sub-grain wall density, as follows:

$$
\frac{\mathrm{d} \rho}{\mathrm{dx}}=\frac{\dot{\varepsilon}}{\mathrm{blm} \mathrm{m}_{\mathrm{HAB}} \tau \rho}-2 \frac{\rho^{2}(\mathrm{x})}{\rho} \frac{\mathrm{M}}{\mathrm{m}_{\mathrm{HAGB}}},
$$


where $\mathrm{x}$ represents the direction of mobility of the migration front; $\mathrm{b}$ is the Burgers vector; 1 is the mean free path of the dislocations, for example, $1 \sim \rho^{-1 / 2} ; \mathrm{m}_{\mathrm{HAB}}$ is the mobility of a high angle grain boundary; $\mathrm{M}$ is the mobility of dislocations; and $\tau$ is the dislocation line energy. Similar approaches to the previous equation have been presented by Bergström [90], Kocks and Mecking [91,92], Estrin and Mecking [93], and Laasraoui and Jonas [43], among a few other authors. The solution of Equation (18) gives $\rho(x)=\rho_{\mathrm{s}} \tanh \left(2 \frac{\rho_{\mathrm{s}}}{\rho} \frac{\mathrm{M}}{\mathrm{m}_{\mathrm{HAB}}} \mathrm{x}\right)$, where $\rho_{\mathrm{s}}$ is the steady state dislocation density representing a balance between work hardening and dynamic recovery, and can be calculated as follows:

$$
\rho_{\mathrm{s}}=\sqrt{\frac{\dot{\varepsilon}}{2 \mathrm{blM} \tau}}
$$

Roberts and Ahlblom [81] have proposed that the nucleation of new grains is based on a critical dislocation density criterion. The new nuclei appears if the cell is located at the grain boundaries and the dislocation density within the cell reaches a critical value $\rho_{c}$, depending on the deformation conditions in the following form:

$$
\rho_{\mathrm{c}}=\left(\frac{20 \mathrm{~S} \dot{\varepsilon}}{3 \mathrm{blm} \mathrm{m}_{\mathrm{HAB}} \tau^{2}}\right)^{1 / 3}
$$

where $S$ is the grain boundary energy per unit of area $\left(\mathrm{J} \cdot \mathrm{m}^{-2}\right)$.

Sommitsch and Mitter [94] reported a theoretical treatment for nucleation, grain growth, and dislocation evolution to model the dynamic recrystallisation of face-centered cubic materials with low stacking fault energy. The model uses the total dislocation density as a state variable and predicts the onset of DRX; the reaching critical conditions for DRX are deduced from maximizing the net free energy based on the nucleation theory of spherical grains.

Some numerical techniques of analysis have been also used to simulate the evolution of the microstructure during DRX, such as the following: Monte Carlo (MC) [95-98], cellular automata (CA) [99-102], phase field (PF) [103], vertex (front tracking) [104,105], and level set [106], among others. Nevertheless, despite all the effort put in the direction of getting a more accurate knowledge of the mechanisms of DRX for application in modelling codes, often, the implementation of these models is a complex and time-consuming operation and requires relatively more simple models, whose application on the experimental data is more practical.

Perdrix [107] studied the flow stress characteristics in hot strip mill conditions through the hot torsion technique on $\mathrm{C}-\mathrm{Mn}-\mathrm{Al}$ steels and $\mathrm{Nb}$ microalloyed steels. The author described in a quantitative manner the effect of strain, strain rate, and temperature on the flow stress behavior of steels. He took into account the influence of deformation conditions on structural changes: recrystallisation kinetics, recrystallised grain size, and grain growth, and used this knowledge to describe the influence of processing variables and steel parameters on the structural behavior of steels after hot deformation. The effect of temperature change between passes and the interaction between successive passes owing to partial recrystallisation was also analyzed. In his work, Perdrix [107] stated that the work hardening rate-stress $(\theta-\sigma)$ curve may be divided into successive domains (I, II, and III), each of these with a negative linear relationship or slope between $\theta$ and $\sigma$ (see Figure 3 ), where $\theta=\left.(\partial \sigma / \partial \varepsilon)\right|_{T, \varepsilon}$. He also analyzed and derived numerical expressions that reflected the influence of the chemical composition of the analyzed steels on the previous values, mainly the effect of $\mathrm{C}, \mathrm{Nb}$, and $\mathrm{Al}$.

Kirihata and co-workers [108] studied the kinetics of static, dynamic, and metadynamic recrystallisation of a $\mathrm{Cr}-\mathrm{Mo}-\mathrm{V}-\mathrm{Ni}-\mathrm{Nb}(0.28 \% \mathrm{C}-0.47 \% \mathrm{C})$ steel by means of torsion testing. In this case, the critical strain for the onset of dynamic recrystallisation was determined from the strain at which the $50.0 \%$ post-dynamic softening time $\left(\mathrm{t}_{0.5}\right)$ becomes independent of strain in the $\mathrm{t}_{0.5}$ versus $\varepsilon$ plot and from the fitting of mean flow stress data measured in hot strip mills. 

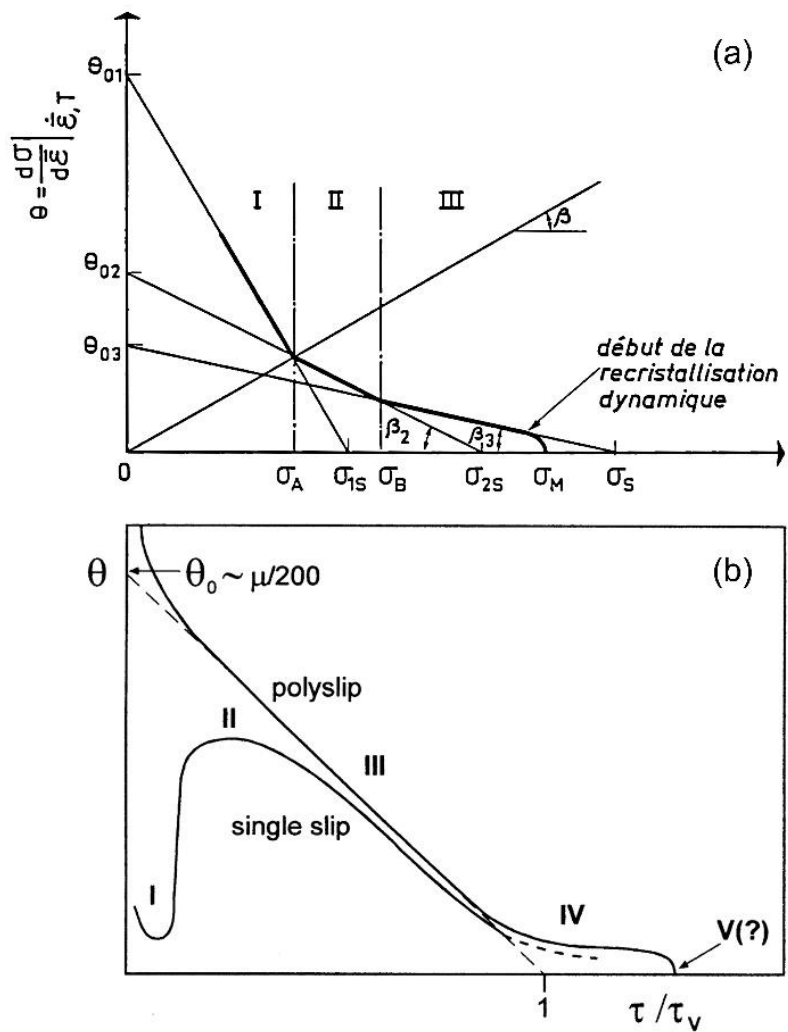

Figure 3. (a) Schematic representation of the strain hardening rate-stress curve $(\theta-\sigma)[107]$ and (b) hardening stages for polycrystals in comparison with those for single crystals deformed in single slip. Reprinted from [92] with permission from Elsevier.

While empirical relationships are recognized in order to determine the critical conditions for microstructural instability for the initiation of DRX, some authors have put effort into establishing more rigorous procedures to provide the critical strain for the onset of DRX. A mathematical approach, initially proposed by Mecking and Kocks [91], and then continued by Ryan and McQueen [78,109], was developed to derive the critical strain. As illustrated in Figure 4, the onset of DRX can be determined from slope changes in the $\theta-\sigma$ curves, which correspond to inflection point of these curves. Ryan and McQueen [109] defined the critical strain as the strain value at which the experimental flow stress curves deviate from the theoretical or "idealized" $\sigma-\varepsilon$ curves when DRV is the only active softening mechanism [26]. Figure $5 b$ shows that extrapolation of the second linear segment of the $\theta-\sigma$ curve until that $\theta$ is equal to zero determines the theoretical $\sigma-\varepsilon$ curve, corresponding to DRV acting as the main restoration mechanism operating $\left(\sigma_{\mathrm{sDRV}}\right)$ [8]. Nevertheless, in this case, the determination of the inflection points and the followed extrapolation procedure was not well defined.

As already stated, Wray [13] highlighted that the critical strain corresponds to the application of a minimum amount of energy required to start DRX. Poliak and Jonas [14,29] have reported a theory about the initiation of DRX mainly based on previous works and energetic considerations $[13,110]$. This alternative approach, based on the thermodynamic laws and principles governing irreversible processes, identifies the onset of DRX by an inflection point in the $\theta-\sigma$ curve, and it is defined as the strain hardening rate corresponding to the appearance of an additional thermodynamic degree of freedom in the system. The authors suggest that further consideration of the stored energy threshold into the material proposed by Wray [13] is essential, but may not be sufficient $[14,29]$. Further, the kinetics of the process must be considered. The stored energy needs to attain a maximum value, while the latter condition demands that the energy dissipation rate reaches a minimum, and it can be quantified in terms of the appearance of a minimum in the variation of the hardening rate $\left(-\partial \theta /\left.\partial \sigma\right|_{T, \dot{\varepsilon}}\right)$ with the stress, as displayed in Figure 5. The approach involves multiple numerical differentiations and 
sometimes promotes a substantial experimental noise during the data treatment. In some cases, the quantity $-\partial \ln \theta /\left.\partial \varepsilon\right|_{\mathrm{T}, \dot{\varepsilon}}$ may be used and the determination of the critical strain becomes easier. Also, it should be noted that, to precisely define the critical strain for dynamic recrystallisation, it is necessary to determine the minimum in $\left(-\partial \theta /\left.\partial \sigma\right|_{\mathrm{T}, \dot{\varepsilon}}\right)$ or the minima in $(-\partial \ln \theta / \partial \ln \sigma)$ and $(-\partial \ln \theta / \partial \varepsilon)[14,29]$. Moreover, this method is applicable to variable strain rate conditions and to any testing technique [111].
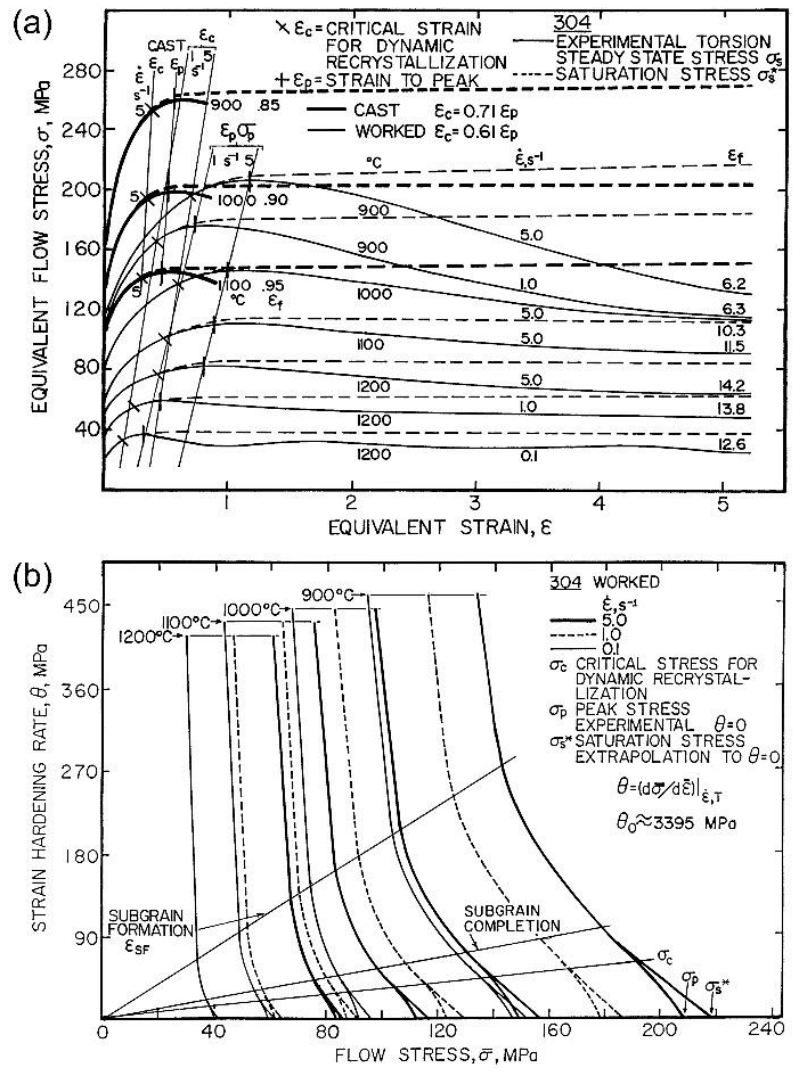

Figure 4. (a) Experimental flow curves of an AISI 304 steel and (b) corresponding experimental $\theta-\sigma$ curves and hypothetical strain hardening rate-stress curves (DRV). Reprinted from [78] with permission from Elsevier.
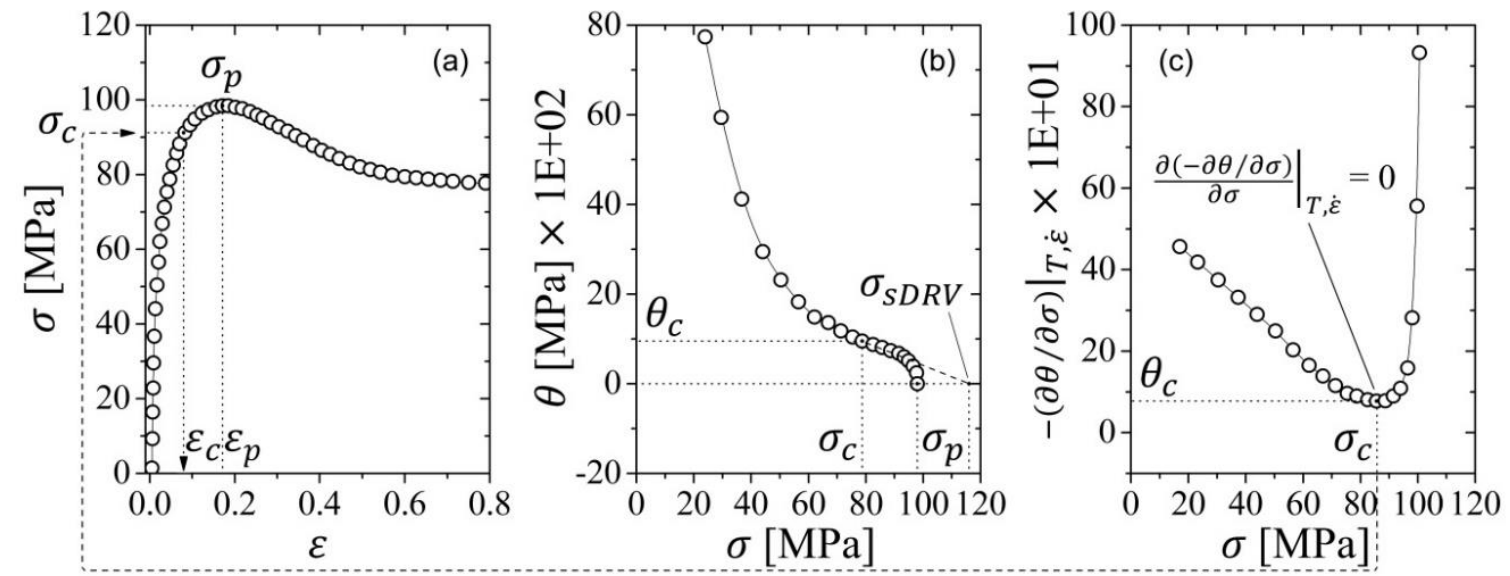

Figure 5. Schematic of the Poliak-Jonas procedure to determine $\varepsilon_{\mathrm{c}}(\mathbf{a})$ flow curve, $(\mathbf{b})$ corresponding work hardening rate $\theta$ vs stress and (c) first derivative of the work hardening rate $\theta$ vs stress $[14,29]$.

Mathematically speaking, the revealing of the inflection points of $\theta-\sigma$ curves suggested by Ryan and McQueen [109] and the minimum values of the $-\partial \theta /\left.\partial \sigma\right|_{\mathrm{T}, \dot{\varepsilon}}$ versus $\sigma$ curves as proposed by Poliak 
and Jonas [14,29] are identical. Thus, it is broadly recognized that the rate of variation in the slope of the $\sigma-\varepsilon$ curve is a strong indicator of the microstructural changes occurring into the material during hot working $[77,78,108,112]$. Najafizadeh and Jonas [113] proposed that the $\theta-\sigma$ curve can be fitted using a third order polynomial equation applied to the normalized $\sigma-\varepsilon$ curve.

Gottstein and co-workers $[11,114]$ have emphasized that strain is not a state variable of crystal plasticity, therefore, there is no sense of a critical strain, rather there are critical conditions for microstructural instability. According to Gottstein et al. [11,114], the approach reported by Poliak and Jonas [14,29] does not offer enough details and lacks of any information about the mechanisms that lead to an instability of the microstructure, and claim that this information can be obtained from a work hardening model that defines substructure evolution and can associate the critical conditions with specific microstructural mechanisms. Accordingly, the deformed state is precisely defined using a three internal variables model (3IVM), namely, (i) the mobile dislocation density, (ii) the dislocation density stored inside the cells, and (iii) the dislocation density stored on the cell walls. The latter authors conceive the strain rate hardening behavior as a combination of different stages (I to V), and the proposed model is essentially a stage-III hardening model under the hypothesis that the deformed state comprises a cellular structure with a high dislocation density in the cell walls, which enclose cell interiors of considerably lower dislocation density [11,114]. The work hardening stage III is controlled by the cross-slip of screw dislocations and can be modeled by computing the evolution of the global dislocation density as the sole internal variable; for example, through the dislocation based strain hardening model reported by Kocks and Mecking [91,92]. Estrin and colleagues [115] have incorporated previous results [116-118] to reproduce and model the work hardening stages III, $\mathrm{IV}$, and V. In order to taking into account the critical conditions for the appearance of the dynamic recrystallisation, Gottstein et al. [11,114] have expressed the volume fraction of dislocations in the cell walls as a function of the strain hardening rate, in agreement with Estrin and co-workers [115]. Moreover, they used different formulations for stage IV and stage V. For stage IV, they assumed that the mobility of sub-boundaries promoted a change in microstructural mechanisms that reveals the inflection point in the $\theta-\sigma$ curve $[11,114]$.

\subsection{Calculation of the Critical Strain Ratio by Applying Constitutive Models}

Typically, several flow stress models, taking into account DRX, comprise the following: (i) a model for strain/work hardening and dynamic recovery, (ii) a nucleation criterion for dynamic recrystallisation, (iii) a function describing the dynamically recrystallised volume fraction (e.g., the well-known Kolmogorov-Johnson-Mehl-Avrami (KJMA) approach [85-88]), and finally (iv) a rule of mixture to determine the macroscopic resulting flow stress. As mentioned above, the Poliak and Jonas method [14,29] comprises multiple differentiation. The direct application of the Poliak and Jonas criterion [14,29], in order to find a relation that describes the onset of recrystallisation (e.g., the critical strain ratio, $\mathrm{R}_{\varepsilon}=\frac{\varepsilon_{\mathrm{c}}}{\varepsilon_{\mathrm{p}}}$ ) in a given constitutive model describing the strain hardening and dynamic recovery stages, is a topic that has not received much attention, and often this task does not always gives satisfactory and precise results. As can be easily seen, such an approach is not applicable in many constitutive models and equations because the second derivative criterion (SDC) [14,29], to determine the critical strain for the initiation of $\operatorname{DRX}\left(\partial\left(-\frac{\partial \theta}{\partial \sigma}\right) /\left.\partial \sigma\right|_{\mathrm{T}, \dot{\varepsilon}}=0\right)$, can give trivial, inaccurate, and/or incongruous solutions. An obvious violation of the SDC occurs when the model for strain hardening and dynamic recovery is incapable of showing an inflection point in the strain hardening rate as a function of the flow stress. Regarding this fact, some authors have developed mathematical approaches to determine the necessary conditions (consistency check) that the constitutive law, describing the strain hardening and the dynamic recovery, must meet to allow the applicability of the Poliak and Jonas criterion [14,29,119]. Bambach [119] shows three types of inconsistencies with the second derivative criterion [14,29] when the effect of dynamic recrystallisation is included in the flow stress model, namely, (i) the model for strain hardening and dynamic recovery do not exhibit an inflection point, 
(ii) the nucleation criterion for DRX is inconsistent with the inflection point in the strain hardening model, and (iii) insufficient differentiability of the function that represents the flow stress.

A number of authors have made numerous attempts to predict both the critical strain for the onset of the dynamic recrystallisation and the critical strain ratio $\mathrm{R}_{\varepsilon}$. In this regard, Ebrahimi and Solhjoo [120], based on a previously published work [121], have determined the critical strain ratio of $\mathrm{Nb}$ steels using a constitutive equation. According to this procedure, the true stress-strain curve was modeled until the maximum stress using the model proposed and reported by Cingara and McQueen [76,122], and described in Equation (21):

$$
\frac{\sigma}{\sigma_{\mathrm{p}}}=\left[\left(\frac{\varepsilon}{\varepsilon_{\mathrm{p}}}\right) \exp \left(1-\frac{\varepsilon}{\varepsilon_{\mathrm{p}}}\right)\right]^{\mathrm{C}},
$$

where $\mathrm{C}$ is a constant value of the material, which is weakly dependent on deformation conditions, and temperature and strain rate and must be determined for each condition [76]. Taking the logarithm of the above equation, the value of the constant $C$ can be obtained as the slope in the linear plot representation of $\ln \left(\frac{\sigma}{\sigma_{\mathrm{p}}}\right)$ versus $\left[1-\left(\frac{\varepsilon}{\varepsilon_{\mathrm{p}}}\right)+\ln \left(\frac{\varepsilon}{\varepsilon_{\mathrm{p}}}\right)\right]$ [121]. Ebrahimi and Solhjoo [120] used the Poliak and Jonas criterion $[14,29]$ to develop an approach for determining the critical strain ratio, as follows:

$$
\mathrm{R}_{\varepsilon}=\frac{\sqrt{1-\mathrm{C}}-(1-\mathrm{C})}{\mathrm{C}} .
$$

Although this method provides a useful mathematical expression to determine the critical strain ratio, some limitations of the approach are observed. The maximum $R_{\varepsilon}$ that can be obtained takes place when the value of $C$ tends to zero, then the maximum value of $R_{\varepsilon}$ tends to 0.50 . Despite the fact that the value of the constant $C$ will be derived for each alloy, it was shown that a unique value could be used for a type or family of alloys (e.g., steels) with a small error [78]. For example, McQueen and Ryan [78] reported values of C ranging between approximately 0.19 and 0.22 for AISI 301, 304, 316, and 317 type steels and values of $\mathrm{C}$ between 0.39 and 0.73 for $\mathrm{C}$ steels, $\mathrm{V}$ steels, $\mathrm{V}-\mathrm{Mo}$ steels, and Ti-Nb steels. Ebrahimi et al. [121] reported a value of C equal to 0.49 for Ti-IF steels. More recently Mirzadeh and Najafizadeh [123], on a precipitation hardening stainless steel (17-4 PH), determined the critical ratio $R_{\varepsilon}$ using the aforementioned approach and obtained a mean value of 0.47 , with $C$ equal to 0.24.

On the similar line of research, Solhjoo [68] assumed a linear relationship between the strain hardening rate and the strain as follows $\theta=\frac{\partial \sigma}{\partial \varepsilon}=a \varepsilon+b$. The solution of the former differential equation with the following boundary conditions, $\sigma=\sigma_{\mathrm{p}}$ at $\varepsilon=\varepsilon_{\mathrm{p}}$ is as follows:

$$
\frac{\sigma}{\sigma_{\mathrm{p}}}=\left[\frac{\varepsilon}{\varepsilon_{\mathrm{p}}}\left(2-\frac{\varepsilon}{\varepsilon_{\mathrm{p}}}\right)\right]^{\mathrm{S}},
$$

where $S$ is an additional parameter that contributes to improving the accuracy of the model and, as in the case of Equation (21), must be determined for each material. Taking the logarithm of Equation (23), the linear regression of the $\ln \left(\frac{\sigma}{\sigma_{p}}\right)$ versus $\ln \left[\frac{\varepsilon}{\varepsilon_{p}}\left(2-\frac{\varepsilon}{\varepsilon_{p}}\right)\right]$ plot gives the value of $S$ constant for each material for each set of temperatures. Solhjoo [68] also found a negative linear relationship between $S$ and temperature. Applying the method proposed by Poliak and Jonas [14,29], to solve $\frac{\partial}{\partial \sigma}\left(-\frac{\partial \theta}{\partial \sigma}\right)=0$ with $\theta=\operatorname{So}\left(\frac{1}{\varepsilon}+\frac{1}{\varepsilon-2 \varepsilon_{\mathrm{p}}}\right)$, the critical strain ratio can be expressed as follows:

$$
R_{\varepsilon}=1-\frac{1}{2} \sqrt{4-2 \frac{6(S-1)+2 \sqrt{S^{2}-6 S+5}}{2 S-1}}
$$

As can be verified, when $S$ tends to 0.5 , the value of $R_{\varepsilon}$ tends to $1-\frac{1}{\sqrt{3}}$, that is, $R_{\varepsilon} \sim 0.42$. In any case, and for Equations (21) and (24), the calculation of the critical ratio also exhibits some limitations. 
The maximum value obtained by applying Equation (21) is less than 0.5 and, for Equation (24), the maximum value of $\mathrm{R}_{\varepsilon}$ remains below $1-\sqrt{\sqrt{5}-2} ;\left(\mathrm{R}_{\varepsilon} \sim 0.51\right)$. According to the experimental results, for an AISI 304 stainless steel tested at temperatures in the interval of $1173 \mathrm{~K}\left(900^{\circ} \mathrm{C}\right)$ and $1473 \mathrm{~K}(1200$ ${ }^{\circ} \mathrm{C}$ ), it was found that the value of the parameter $\mathrm{S}$ varies between 0.20 and 0.41 , giving values of $R_{\varepsilon}$ between 0.44 and 0.48 [68].

In order to contribute to the simplification of the problem, the authors of the present review state that Equation (24) can be replaced by the following expression:

$$
R_{\varepsilon}=1-\sqrt{\frac{1}{\sqrt{S^{2}-6 S+5}+(2-S)}} .
$$

Lately, Solhjoo [124] proposed a new constitutive equation to predict the flow stress at high temperature up to the peak of stress-strain curve, constructed on the basis of the general form of hyperbolic tangent function, as follows:

$$
\sigma=\sigma_{0}+\left(\sigma_{\mathrm{p}}-\sigma_{0}\right)\left[\tanh \left(2 \varsigma \frac{\varepsilon}{\varepsilon_{\mathrm{p}}}\right)\right]^{\mathrm{K}_{2}}
$$

where $\sigma_{0}, \varsigma$, and $K_{2}$ are the initial stress and material constants, respectively. Solhjoo [124] claim that the use of this formulation includes an additional exponent to highly increase the accuracy of the model. Through the mathematical manipulation of the above equation, it is possible to develop a method to determine the value of the mentioned material constants. The values of $\zeta$ and $\mathrm{K}_{2}$ can be obtained as the slope in the linear plot representations of $\tanh ^{-1}\left(\frac{\sigma-\sigma_{0}}{\sigma_{\mathrm{p}}-\sigma_{0}}\right)^{\frac{1}{K_{2}}} \operatorname{versus}\left(2 \frac{\varepsilon}{\varepsilon_{\mathrm{p}}}\right)$ and $\ln \left(\frac{\sigma-\sigma_{0}}{\sigma_{\mathrm{p}}-\sigma_{0}}\right)$ versus $\ln \left[\tanh \left(2 \varsigma \frac{\varepsilon}{\varepsilon_{\mathrm{p}}}\right)\right]$, respectively. The material constants $\varsigma$ and $\mathrm{K}_{2}$ are interdependent variables and can be determined using different mathematical methods. Solhjoo [124] argued that the approach represented by Equation (26) shows a powerful capability to predict the flow stress and that it is the first constitutive equation with this kind of parameter. Furthermore, using the Poliak and Jonas criterion [14,29], the author derived an equation that can be used to predict the critical strain ratio $R_{\varepsilon}$, and it is expressed as follows:

$$
\mathrm{R}_{\varepsilon}=\frac{1}{\varsigma} \tanh ^{-1}\left(\sqrt{\frac{1-\mathrm{K}_{2}}{1+\mathrm{K}_{2}}}\right) .
$$

Unlike the above expressions (Equations (21) and (24)), Equation (26) does not exhibit upper limitations in the calculated value of the critical strain ratio $R_{\varepsilon}$. However, an inadequate value of $\varsigma$ and/or $K_{2}$ can promote erroneous values of $R_{\varepsilon}$; for example, $R_{\varepsilon}$ greater than 1 . Solhjoo [124] successfully applied this approach on AISI 304 austenitic stainless steel data. In this case, and in an opposing manner to the approach of Equation (24), constants $\varsigma$ and $K_{2}$ were independent from the hot deformation parameters (true strain rate and temperature) and mean values of $\sim 1.28$ and $\sim 0.68$, respectively, were determined. Finally, the reported value for the critical strain ratio was $R_{\varepsilon} \sim 0.38$. It is useful to mention that, in this case, the domain of the function represented by Equation (27) always requires values of $K_{2}$ greater than zero and less or equal than 1 .

Chen et al. [125] have presented a new model to describe the flow stress up to the peak of the $\sigma-\varepsilon$ curves and, applying the SDC [14,29], the authors derive an expression to calculate the critical strain ratio $R_{\varepsilon}$. In this case, the flow curve up to the peak stress was modeled using the following equation:

$$
\frac{\sigma}{\sigma_{\mathrm{p}}}=1-\exp \left(\psi\left(\frac{\varepsilon}{\varepsilon_{\mathrm{p}}}\right)^{\zeta}\right)
$$


where $\psi$ and $\zeta$ are interdependent numerical material constants. The solution of the second derivative criterion $\left.\left(\frac{\partial^{2} \theta}{\partial \sigma^{2}}\right)\right|_{T, \dot{\varepsilon}}=0[14,29]$ promotes the following expression for the critical strain ratio:

$$
R_{\varepsilon}=\left(\frac{1}{\psi \zeta}\right)^{\frac{1}{\zeta}}
$$

Chen et al. [125] have developed a model used to predict the stress-strain curves of X12 an ultra-super-critical rotor steel. By applying Equation (29), $R_{\varepsilon}$ is determined to be equal to 0.43, which is in agreement with the experimental value obtained using the approach reported by Najafizadeh and Poliak [113].

In a relatively recent paper, Jonas et al. [126] reanalyzed previously published hot flow data [127] and contemplated the dynamic transformation (DT) as an additional softening mechanism (in addition to DRV and DRX) that contributes to the microstructural and mechanical softening responsible for the classical single-peak-shaped curve. Jonas et al. [126] applied the double differentiation method, reported previously by Poliak and Jonas [14,29], to three steels (low C steel, Nb-modified steel, and $\mathrm{Nb}$-modified TRIP steel), tested under uniaxial isothermal compression at constant true strain rates ranging from 0.05 to $1.0 \mathrm{~s}^{-1}$ and temperature ranging between $1223 \mathrm{~K}\left(\left(950^{\circ} \mathrm{C}\right)\right.$ and $1423 \mathrm{~K}\left(1150{ }^{\circ} \mathrm{C}\right)$. Accordingly, the authors also considered and analyzed the effect of the polynomial order (2 to 15) on the sensitivity of the double differentiation method as well as on the actual values of the critical strains determined. The double differentiation method normally requires the use of polynomial fitting functions of at least the eighth order and the use polynomials of lower degrees can cause a poor accuracy in the fitting process. Using the first part of the flow curve, comprising values of strain below the peak strain of the TRIP steel curves $\left(1423 \mathrm{~K}\left(1150{ }^{\circ} \mathrm{C}\right)\right.$ and $\left.0.25 \mathrm{~s}^{-1}\right)$, Jonas et al. [126] stated that polynomial orders below 3 are unable to detect any minima at all, whereas polynomial order between 4 and 7 can detect the DRX minima, but are unable to identify the DT minima. On the other hand, for polynomials order above 8 and/or even higher, both minima are distinguished. Although the order has a detectable effect on the flow stress associated with the minimum, it leads to small differences in the derived critical strains. The critical strain values for DT show a small dependence on polynomial order. However, the critical strain values for DRX show some scatter and these differences can be associated to the actual value of true strain and to the slope of the flow curve after yielding. Finally, Jonas et al. [126] concluded that all the DT critical strains were within about $\pm 0.5 \%$ of the average value and the DRX critical strains were within about $\pm 2.0 \%$.

The traditional way to determine the initiation of dynamic recrystallisation reported by Poliak and Jonas [14,29] comprises a relatively complex and time-consuming procedure of manipulation and processing of data, including several steps, such as smooth and filter the raw data, conversion to stress-strain data, compensate the stress drop owing to adiabatic heating or fiction (dissipation heating), second smoothing steps, determination of $\theta$, and so on. Lohmar and Bambach [128] have developed a new concept and an alternative criterion to the Poliak-Jonas method [14,29] in the determination of the onset of DRX. They have proposed the use of a special surface interpolation method based on radial basis functions (RBFs) using a thin plate spline (TPS) kernel to approximate several flow curves at once and to smooth the course of $\sigma$ over both $\varepsilon$ and $T$ via regularization methods [129]. This technique combines surface interpolation of various hot flow curves and smoothing in a single step. As mentioned above, and in some cases, the Poliak and Jonas method [14,29] involves the use of a multiple smoothing steps (e.g., using fast Fourier transform-based procedures, FFT). Accordingly, Jonas et al. [130] applied a seventh-order polynomial, and in some cases, a higher-order polynomial, to fit and smooth each $\sigma-\varepsilon$ curve and a third-order polynomial in the description of the strain hardening rate versus flow stress data, $\theta-\sigma$ [113]. Lohmar and Bambach [128] stated that this type of approach, the use of an i-th order polynomial in the smoothing steps, promotes distinct roots (solution candidates) in the interval of true strains below to the peak strain, $\varepsilon_{\mathrm{p}}$. Consequently, in some cases, no unique critical point $\varepsilon_{\mathrm{c}}$ and several ambiguous candidate values are obtained. According to Lohmar and 
Bambach [128], the explicit representation of the flow stress, as a function of strain and temperature $\sigma(\varepsilon, T)$, involves the solution of the following minimization problem:

$$
\frac{1}{n} \sum_{i=1}^{n}\left(\sigma\left(\varepsilon_{i}, T_{i}\right)-\sigma_{i}\right)^{2}+\lambda \sum_{j=1}^{m}\left(\begin{array}{c}
m \\
j
\end{array}\right) \iint_{\Re^{2}}\left(\frac{\partial^{m} \sigma(\varepsilon, T)}{\partial^{\mathrm{j}} \partial^{m-j}}\right)^{2} d \varepsilon d T \rightarrow \text { min, }
$$

where $\lambda$ is a regularization parameter that describes the trade-off between interpolation and approximation. For constant strain rate and a continuous solution, $\sigma(\varepsilon, \mathrm{T})$ is of the following form:

$$
\sigma(\varepsilon, \mathrm{T})=\sum_{\mathrm{i}=1}^{\mathrm{n}} \mathrm{a}_{\mathrm{i}} \phi_{\mathrm{i}}(\varepsilon, \mathrm{T})+\mathrm{a}_{\mathrm{n}+1} \varepsilon+\mathrm{a}_{\mathrm{n}+2} \mathrm{~T}+\mathrm{a}_{\mathrm{n}+3},
$$

where the thin plate spline kernel is defined as follows:

$$
\phi_{\mathrm{i}}(\varepsilon, \mathrm{T})=\left(\left\|(\varepsilon, \mathrm{T})-\left(\varepsilon_{\mathrm{i}}, \mathrm{T}_{\mathrm{i}}\right)\right\|_{2}\right)^{2} \ln \left\|(\varepsilon, \mathrm{T})-\left(\varepsilon_{\mathrm{i}}, \mathrm{T}_{\mathrm{i}}\right)\right\|_{2} .
$$

By solving a system of $n+3$ linear equations, the unknown coefficients $a_{i}$ are calculated. After solving the coefficients $a_{i}$ and partially deriving the TPS kernel (Equation (32) with respect to strain, the work hardening rate and the representation of the Poliak-Jonas criterion $[14,29]$ are shown, respectively, as follows:

$$
\begin{gathered}
\theta(\varepsilon, \mathrm{T})=\left(\frac{\partial \sigma}{\partial \varepsilon}\right)=\sum_{\mathrm{i}=1}^{\mathrm{n}} \mathrm{a}_{\mathrm{i}} \phi_{\mathrm{i}}^{\prime}(\varepsilon, \mathrm{T})+\mathrm{a}_{\mathrm{n}+1}, \\
\frac{\partial}{\partial \sigma}\left(-\frac{\partial \theta}{\partial \sigma}\right)=\frac{\left(\theta^{\prime}\right)^{2}-\theta^{\prime \prime} \theta}{\theta^{3}} \equiv \kappa(\varepsilon),
\end{gathered}
$$

where $k(\varepsilon)=0$ reflects the roots of the $\frac{\partial}{\partial \sigma}\left(-\frac{\partial \theta}{\partial \sigma}\right)$ versus $\varepsilon$ curve; for example, the critical strain candidates.

Lohmar and Bambach [128] have claimed that the developed TPS method requires a minima additional preparation of the flow strain-stress data. The improvement of this new approach lies in the convenient way to interpolate multiple strain-stress flow curves with a differentiable surface interpolant. Finally, Lohmar and Bambach [128] remarked that the TPS approach seems to be a more robust determination of the critical strain for the onset of DRX in comparison with the polynomial interpolation proposed by Jonas et al. [130], which occasionally yields multiple candidates for critical points. However, some limitations are cited, namely, at lower temperatures, the compensation of dissipation heating might affect the determination of the critical conditions for the onset of DRX and cause the detection of rather low critical strain ratios.

\section{Influence of the Chemical Composition on the $m$ Exponent}

One of the main objectives of this review work is to reveal or expose the effect of the chemical composition of the alloy on the value of the m exponent, fundamentally for Equations (1a) and (1b). This exponent somehow reflects and controls the kinetics of the process as it is closely related to the true strain rate, for example, through the Zener-Hollomon parameter Z [30]. Regarding this, it was considered that the chemical content of the alloys is an index to evaluate the effect of the chemical composition on the DRX kinetics, and here, the equivalent carbon content $\left(C_{\text {eq }}\right)$ was used as an indicator to evaluate the effect of compositions. For example, in welding, the hardenability of the steel is often expressed using a carbon equivalent content. The concentration of each solute is scaled by a coefficient, which expresses its ability, relative to $C$ content, to retard the austenite/ferrite transformation. Bhadeshia and Honeycombe [131] have stated that the increased sensitivity of the austenite to ferrite transformation to carbon at lower concentrations leads to a decreased sensitivity to substitutional alloying elements. It is interesting that the sensitivity of transformation kinetics 
to carbon at low concentrations explains the need recognized widely in industry, for two carbon equivalent formulae to cover the low and high (>0.18 wt. \%C) carbon steels (see Equations (35) and (36), respectively). These are in fact the two most popular expressions for $\mathrm{C}_{\mathrm{eq}}$. The IIW formula (International Institute of Welding, Equation (36)) shows much smaller tolerance to substitutional alloying elements than Equation (35), also known as the Ito-Besseyo formula. Other similar expression can be found in the literature $[43,132]$.

$$
\mathrm{C}_{\mathrm{eq}}=\% \mathrm{C}+\frac{\% \mathrm{Si}}{30}+\left(\frac{\% \mathrm{Mn}+\% \mathrm{Cu}+\% \mathrm{Cr}}{20}\right)+\frac{\% \mathrm{Ni}}{5}+\frac{\% \mathrm{Mo}}{15}+\frac{\% \mathrm{~V}}{10}+5 \% \mathrm{~B},
$$

for $\mathrm{C}<0.18 \%$ and

$$
\mathrm{C}_{\mathrm{eq}}=\% \mathrm{C}+\left(\frac{\% \mathrm{Mn}+\% \mathrm{Si}}{6}\right)+\left(\frac{\% \mathrm{Ni}+\% \mathrm{Cu}}{15}\right)+\left(\frac{\% \mathrm{Cr}+\% \mathrm{Mo}+\% \mathrm{~V}}{5}\right),
$$

for $C \geq 0.18 \%$.

The Ito-Besseyo approach, Equation (35), has smaller coefficients for the substitutional solutes when compared with the IIW equation. It is believed to be more reliable for low-carbon steels. On the other hand, the IIW formula, Equation (36), shows much smaller tolerance to substitutional alloying elements [131].

In the previous equations, all the percentages are expressed in weight percent (wt. \%). The use of the alloy content instead of the activation energy, in order to reveal the effect of the chemical composition, was preferred. Numerous authors use calculated apparent activation energy values, determined from experimental data, as an alternative to employ the self-diffusion activation energy. However, the activation energy also will be taken into account in the discussion of results as an additional criterion of analysis. It usually takes values similar or somewhat above those for self-diffusion, indicating that deformation under the discontinuous dynamic recrystallisation phenomena is thermally activated and involves self-diffusion mechanisms [1].

Table A1 in Appendix A collects the most relevant and valuable data obtained from the scientific literature from several families of steels, namely, low alloy steels (e.g., plain carbon steels), carbon steels, microalloyed steels, stainless steels, and high alloy steels (e.g., TRIP and TWIP steels). The fields of Table A1 comprise the following: the main chemical composition of the alloy expressed in weight percentage (wt. \%); a brief indicator of the type of alloy (steel); the testing methodology (C: compression, T: torsion, R: rolling, TE: tension, M: multiple techniques); the mean diameter of the initial austenitic grain size $\mathrm{d}_{0}$ expressed in microns $(\mu \mathrm{m})$; the activation energy for hot working $\mathrm{Q}_{\mathrm{hw}}$ used to calculate $\mathrm{Z}$ (expressed in $\mathrm{kJ} \cdot \mathrm{mol}^{-1}$ ); the parameters $\mathrm{k}, \mathrm{K}, \mathrm{n}$, and $\mathrm{m}$ of the aforementioned equations (Section 2.2); and the critical strain ratio $\mathrm{R}_{\varepsilon}$ and the type of equation considered. The chemical composition of the alloys is represented by the $\mathrm{C}, \mathrm{Mn}, \mathrm{Si}, \mathrm{Al}, \mathrm{Cr}, \mathrm{Ni}, \mathrm{Mo}, \mathrm{Ti}, \mathrm{Nb}, \mathrm{V}$, and $\mathrm{B}$ contents, whereas the values of $\mathrm{P}$, $\mathrm{S}, \mathrm{N}$, and $\mathrm{O}$, among many others, have been omitted. When a large number of alloys are reviewed, the chemical composition is noticed using only the range of variation of the chemical elements as an interval of values (e.g., 0.12-0.25 C). When a specific chemical element does not belong to the all analyzed alloys, it is placed between parentheses (e.g., (0.005 Mo)). In some cases (especially for torsion tests), the initial grain size corresponds to the grain size in a given entry passes. The data corresponding to the critical strain equations for the onset of the DRX are shaded in grey. For simplicity, in many cases, some values in Table A1 and text were rounded and, in some specific cases, the chemical composition of steels was referenced as an average chemical composition.

Figure 6 shows the relation between the $m$ exponent and the alloy content in terms of equivalent carbon amount $\left(\mathrm{C}_{\mathrm{eq}}\right)$. Further, Figure 7 displays the dependence of the activation energy $\mathrm{Q}_{\mathrm{hw}}$ on the equivalent carbon. The test methodology is indicated in both figures. Here, it is worth mentioning that the value of the exponent $\mathrm{m}$ is the exponent accompanying the Zener-Hollomon parameter $\mathrm{Z}$ and/or the exponent accompanying the true strain rate in the different reported equations either for peak strain and critical strain equations. See Section 2.2. 

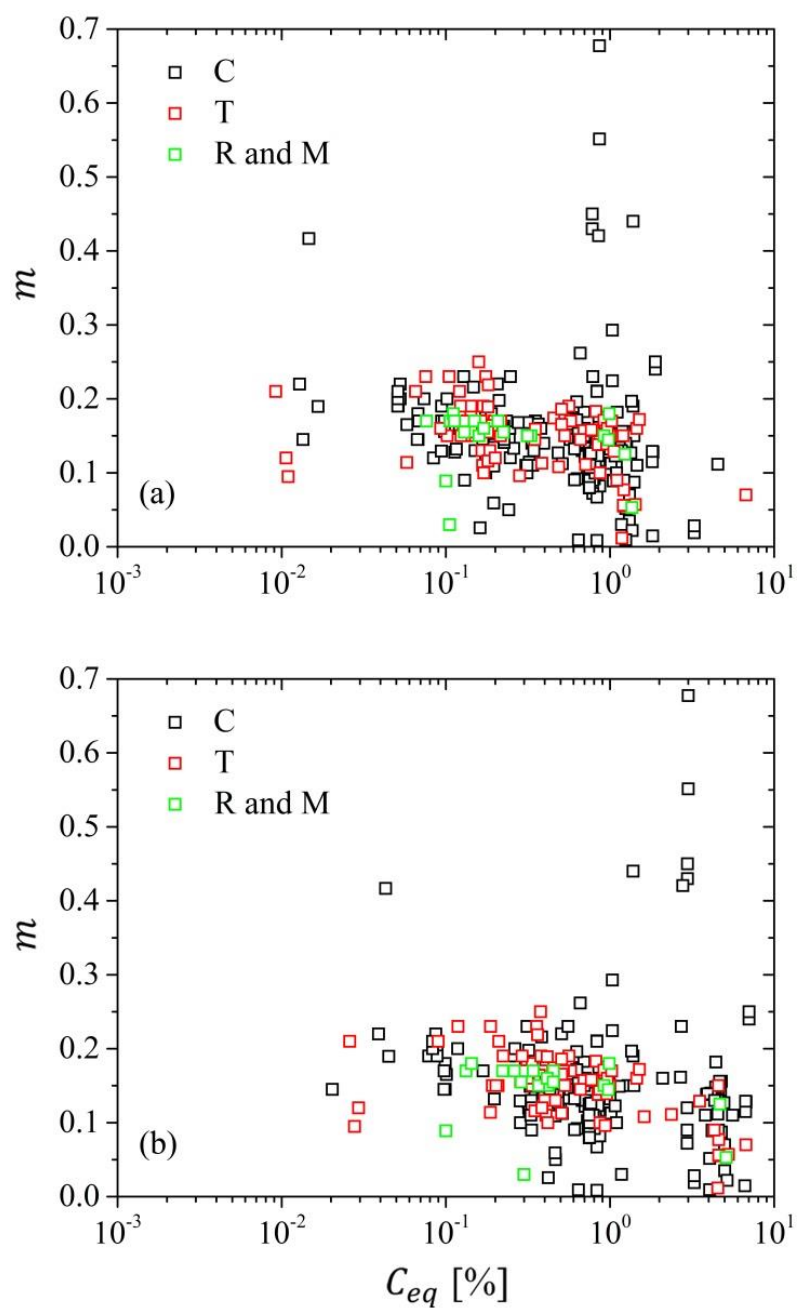

Figure 6. Exponent values $(\mathrm{m})$ as a function of the carbon equivalent of the alloys $\left(\mathrm{C}_{\mathrm{eq}}\right)$ : $(\mathbf{a})$ using Equations (35) and (36) and (b) using Equation (36).

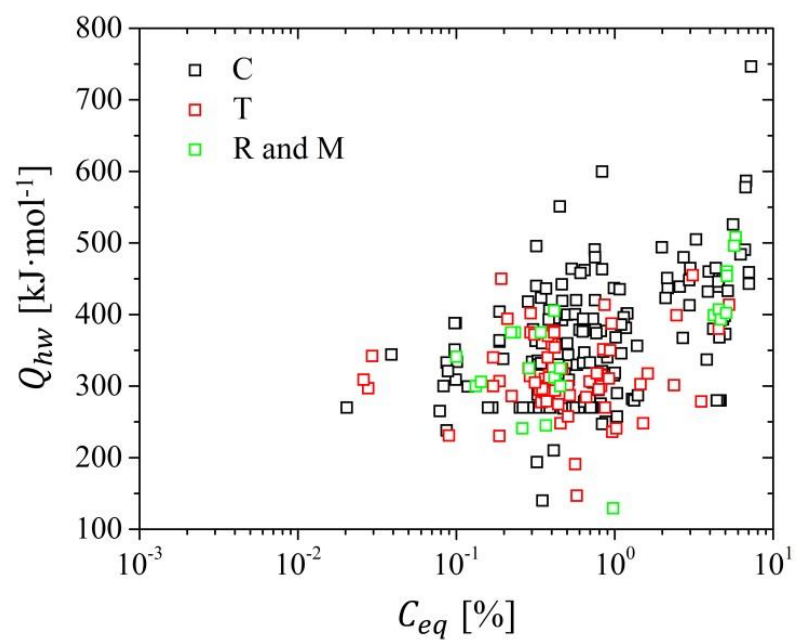

Figure 7. Activation energy vs. the carbon equivalent of the alloys $\left(\mathrm{C}_{\mathrm{eq}}\right)$ using Equation (36).

Nearly 320 experimental data were analyzed, where approximately $65.0 \%$ of them correspond to compression data, $30.0 \%$ to torsion data, and the rest to multiple techniques and tension data. See Figure 8 and Table 1. The statistical analysis of data reveals a mean value of $m$ approximately close to 0.152 with a standard deviation of 0.07 and minimum and maximum values of 0.08 and 0.68 , 
respectively. Moreover, the value at which the discrete probability distribution takes its maximum value (mode) has been 0.150 . Regarding the activation energy $\mathrm{Q}_{\mathrm{hw}}$, the statistical analysis of data reveals a mean value of $347 \mathrm{~kJ} \cdot \mathrm{mol}^{-1}$, with a standard deviation of $81 \mathrm{~kJ} \cdot \mathrm{mol}^{-1}$. The minimum and the maximum values are $129 \mathrm{~kJ} \cdot \mathrm{mol}^{-1}$ and $747 \mathrm{~kJ} \cdot \mathrm{mol}^{-1}$, respectively. As a general trend it can be seen that the strain rate exponent $\mathrm{m}$ decreases slightly with the increasing carbon equivalent of the alloy, and the opposite seems to happen with the activation energy (see Figure 7).
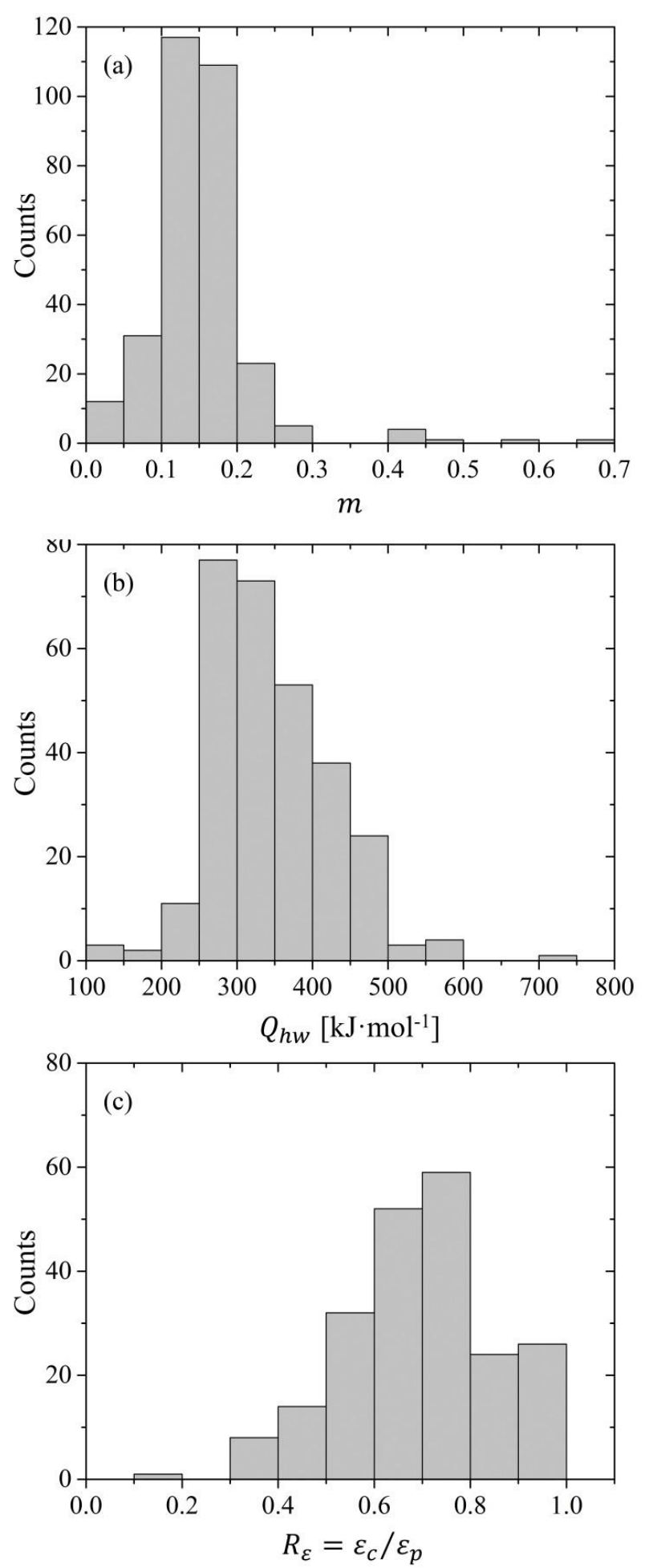

Figure 8. Statistical analysis of the reviewed data: (a) $\mathrm{m},(\mathbf{b}) \mathrm{Q}_{\mathrm{hw}}$, and (c) $\mathrm{R}_{\varepsilon}$. 
Accordingly, an increase of the carbon equivalent content would cause, though slight, slowing of the kinetics of DRX accompanied by a greater insensitivity to the deformation conditions (Z). Solute addition generally restricts the dislocation mobility and reduces the ability of the alloy to dynamically recover acting on the migration of grain boundaries, promoting a major tendency for DRX. However, as DRX also depends on the ease of the migration of grain boundaries, the rate of DRX may decrease for higher solute values. Flow stress is increased by solute and/or fine particles, which diminish DRV, raising the dislocation density through pinning by atmospheres or through reduction in SFE. Fine particles reduce grain boundary mobility and also pin dislocations and stabilize a denser substructure, thus also retarding DRX nucleation. As the peak strain is raised by the presence of solutes and fine particles, the stress is raised more than by simple strain hardening increase, that is, just by the dislocation-dislocation interaction, thus causing a marked rise in activation energy in alloy steels $[77,78]$. There is scarce literature information regarding the effect of the chemical composition or alloy content on the value of $\mathrm{m}$, though few authors observed that the $\mathrm{m}$ exponent decreases with increasing alloy content. Escobar et al. [133], for carbon steels tested at $1173 \mathrm{~K}\left(900^{\circ} \mathrm{C}\right)-1373 \mathrm{~K}\left(1100^{\circ} \mathrm{C}\right)$ and $1.0 \times 10^{-4}$ to $1.0 \times 10^{-1} \mathrm{~s}^{-1}$, have argued that the onset of DRX becomes insensitive to the forming conditions for relatively high carbon (or relatively high alloy) steels and pointed to a slight decrease of $\mathrm{m}$ as the alloying content rises. Dealing with austenitic binary Fe-Mn alloys (1\%Mn-20\%Mn), Cabañas and co-workers [134], under constant initial grain size, have studied the influence of the Mn content on the constitutive equations in the temperature range of $1223 \mathrm{~K}\left(950^{\circ} \mathrm{C}\right)$ to $1523 \mathrm{~K}\left(1250{ }^{\circ} \mathrm{C}\right)$ and the strain rate range of $1.0 \times 10^{-1}$ to $2.0 \mathrm{~s}^{-1}$. The authors pointed out that the critical strain can be expressed as a function of Mn content in a similar manner to Equation (1b); however, in this case, the value of the exponent $\mathrm{m}$ was a linear function of the Mn content of the alloy as follows:

$$
\mathrm{m}=0.020 \% \mathrm{Mn}+0.0855
$$

Cabañas et al. [134] have also reported a decrease of the m exponent from 0.125 to 0.085 , for increasing contents of Mn from 1.0\% to 20.0\% respectively. Varela-Castro [135] have analysed the hot working behavior of structural steels and the dependence with the $\mathrm{C}, \mathrm{Si}$, and $\mathrm{Mn}$ content. The hot flow behavior was studied by isothermal uniaxial compression in the range of $1173 \mathrm{~K}\left(900^{\circ} \mathrm{C}\right)$ to $1373 \mathrm{~K}$ $\left(1000^{\circ} \mathrm{C}\right)$, applying true strain rates ranging between $5.0 \times 10^{-4}$ and $1.0 \times 10^{-1} \mathrm{~s}^{-1}$. Regarding this, eight different steels were refined via the electro-slag remelting technique (ESR) with the following chemical composition range (wt. \%): $\sim 0.15 \% \mathrm{C}-0.45 \% \mathrm{C}, \sim 0.20 \% \mathrm{Si}-0.40 \% \mathrm{Si}$, and $\sim 0.70 \% \mathrm{Mn}-1.60 \% \mathrm{Mn}$, $\% \mathrm{Fe}$ (bal.). The author proposed a complete constitutive model that describes the hot working behavior of $\mathrm{Fe}-\mathrm{C}-\mathrm{Si}-\mathrm{Mn}$ alloys, where all the characteristic parameters are a function of the chemical composition of the alloy and where the parameters to determine the peak strain are defined as follows (see Equation (1b)) [135]:

$$
\mathrm{K}, \mathrm{m}=\mathrm{a}[\% \mathrm{C}]+\mathrm{b}[\% \mathrm{Si}]+\mathrm{b}[\% \mathrm{Mn}]+\mathrm{d},
$$

where $a, b, c$, and d are numerical constants, both obtained with a Pearson's coefficient of $\mathrm{R}^{2} \sim 0.97$. All the percentages are expressed in wt. \%. See Table 2.

Table 2. Parameters of Equation (1b) according to Equation (38) reported by Varela-Castro [135].

\begin{tabular}{ccccc}
\hline \multirow{2}{*}{ Parameter } & \multicolumn{4}{c}{ Numerical Constant } \\
\cline { 2 - 5 } & $\boldsymbol{a}$ & $\boldsymbol{b}$ & $\boldsymbol{c}$ & $\boldsymbol{d}$ \\
\hline$K \times 10^{-3}$ & 3.665 & 2.375 & -0.590 & 6.330 \\
$m$ & -0.053 & -0.008 & 0.006 & 0.168 \\
\hline
\end{tabular}

It can be seen from Table 2 that, for the pre-exponential parameter $K$, the effects caused by $C$ and $\mathrm{Si}$ contents are of the equal order of magnitude and direction (equal sign) and with the influence of $\mathrm{Mn}$ one order of magnitude smaller and of the opposite direction. Regarding the parameter $\mathrm{m}$, it can be 
noticed that the greater absolute effect is exerted by C, whereas Si and Mn exhibit behaviors of an order of magnitude smaller and of opposite signs. Both $\mathrm{C}$ and $\mathrm{Si}$ help to reduce the $\mathrm{m}$ parameter; that is, increase the insensitivity of $\mathrm{m}$ with $\mathrm{Z}$. In this case, the $\mathrm{Z}$ parameter was calculated using a commonly reported value of the self-diffusion activation energy for pure iron $\left(270 \mathrm{~kJ} \cdot \mathrm{mol}^{-1}\right)$ [136-138].

Very recently, Siyasiya and Stumpf [139] have studied the relationship between the chemical composition and the Zener-Hollomon exponent in the peak strain equation for hot working of C-Mn steels. The hot deformation behavior of twelve $\mathrm{C}-\mathrm{Mn}$ steels was examined applying compression tests in which the carbon and manganese contents were increased systematically between $0.035 \% \mathrm{C}$ up to $0.52 \% \mathrm{C}$ and $0.22 \% \mathrm{Mn}$ to $1.58 \% \mathrm{Mn}$, respectively. In addition, data from other authors were analyzed and used to derive the main results of this investigation. The authors suggested that the apparent activation energy for hot working increases with an increase in C content in plain C-Mn steels, as was also found by other researchers. Also, the authors argued that this is possibly because of the retarding effect that the $\mathrm{Mn}-\mathrm{C}$ complexes have on the movement of dislocations. The exponent $\mathrm{m}$ in the peak strain equation for hot working was found to decrease with an increase in $\mathrm{k}$ and $\mathrm{Q}_{\mathrm{hw}}$ (both of which increase with an increase in the $\mathrm{C}$ content), and also decrease with an increase in the $\mathrm{C}$ content according to $\mathrm{m}=0.21-14[\% \mathrm{C}]$, for content of carbon less than $0.8 \% \mathrm{C}$ [139].

On the other hand, Figure 7 shows that the activation energy remains approximately constant $\left(330 \mathrm{~kJ} \cdot \mathrm{mol}^{-1}\right)$ for carbon equivalent values below to $1.0 \%$ and, as the alloy content increases, the reported values of hot working activation energy show an increase. Likewise, it can be noted that collected data are grouped in different areas: (i) high alloyed steels, such as stainless steels at the highest values of $\mathrm{C}_{\mathrm{eq}}$ (about 2.0 or more); (ii) medium alloyed steels, such as medium carbon and microalloyed steels at $\mathrm{C}_{\mathrm{eq}}$ between $0.2 \%$ and $1.0 \%$; and (iii) low alloy steels at carbon equivalent values lower than $0.2 \%$,

The plot presented in Figure 6 also shows that there is not a clear dependence of the test type, whether compression, torsion, or tensile test, on the $\mathrm{m}$ exponent. Several authors have already suggested that higher values of $\varepsilon_{\mathrm{p}}$ are expected in torsion (associated to $\mathrm{k}$ and/or $\mathrm{K}$, approximately by a factor of $\sim 1.3$ to 2.6), in relation to those obtained through compression testing techniques $[27,108]$. However, there have been no reports about the influence of the testing methodology on the DRX kinetics using expressions, as shown in Section 2.2.

Figure 9 represents more than 210 experimental data, mainly for compression and torsion, where the critical strain ratio $R_{\varepsilon}$ is plotted against the carbon equivalent $C_{\text {eq }}$. In this case, the statistical analysis reveals a mean value for $R_{\varepsilon}$ of approximately 0.71 , with a standard deviation of 0.16 and with minimum and maximum values of 0.12 and 1.0, respectively. Furthermore, there is a slight decrease of the critical strain ratio $R_{\varepsilon}$ for increasing values of the alloy content and a mean value of $\mathrm{R}_{\varepsilon}$ of approximately 0.62 , for $\mathrm{C}_{\mathrm{eq}}$ ranging between $4.0 \%$ and $6.0 \%$, is shown. Additionally, the plotted data do not show a clear relationship between the critical strain ratio $R_{\varepsilon}$ values and the testing technique. However, it appears that the data reported for torsion tests have a lower standard deviation (approximately 0.13). It can be also observed that one of the most repeated values for the critical strain ratio is around 0.80 , as has been reported earlier by Sellars [33] for C-Mn steels $\left(\mathrm{R}_{\varepsilon} \sim 0.67-0.86\right)$. Here, it is useful to clarify that many of the reported values are determined or calculated by the Poliak and Jonas method [14,29], although, for many other cases, the authors collect data directly from the reported literature. 


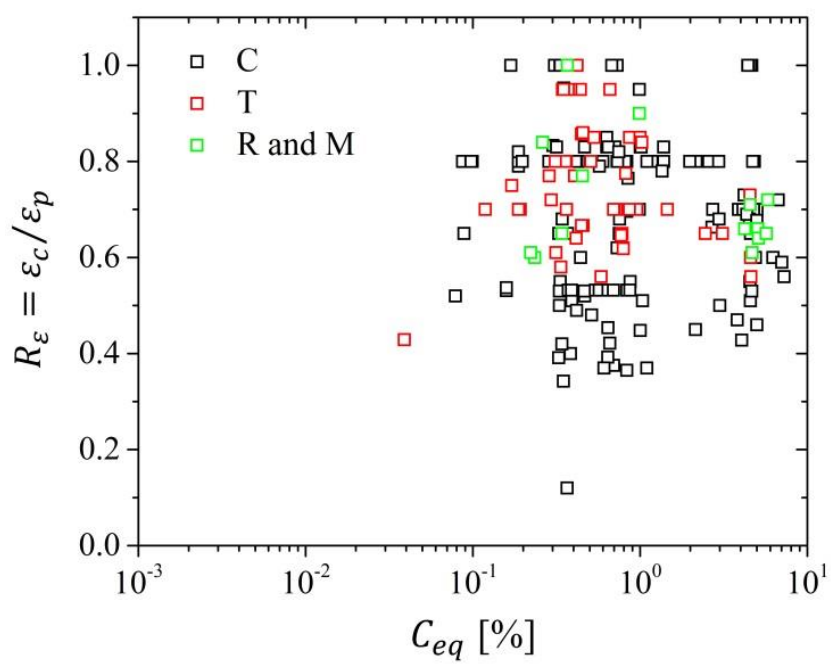

Figure 9. Critical strain ratio $R_{\varepsilon}$ vs. carbon equivalent of the alloys $\left(C_{e q}\right)$ using Equation (36).

A few results were reported regarding the influence of chemical composition and alloy content on the decrease of the critical strain ratio. Siciliano and Jonas [28], for $\mathrm{Nb}$ containing steel, have reported a clear progressive decreasing dependence of the critical strain ratio $R_{\varepsilon}$ solely on the effective niobium concentration $\left(\mathrm{Nb}_{\mathrm{eff}}\right)$, as shown in Equation (39). More recently, Xu et al. [140], for high-Nb HSLA steels, have shown a similar relation updated for higher effective $\mathrm{Nb}$ contents. The authors claims that the model proposed by Siciliano and Jonas [28] is only available to the relatively low effective $\mathrm{Nb}$ contents (i.e., smaller than $0.06 \%$ ) and that there is a large deviation between predictions and measurements for the higher effective $\mathrm{Nb}$ content (up to $0.1 \%$ ).

$$
\mathrm{R}_{\varepsilon}=0.8-\mathrm{aNb}_{\mathrm{eff}}+\mathrm{bNb}_{\mathrm{eff}^{\prime}}^{2}
$$

where $\mathrm{a}$ and $\mathrm{b}$ are constants (10.8 to 13.0 and 64.4 to 112.0 , respectively $[28,140])$ and where $\mathrm{Nb}_{\text {eff }}$ is specified by the following [28]:

$$
\mathrm{Nb}_{\text {eff }}=\% \mathrm{Nb}-\frac{\% \mathrm{Mn}}{120}+\frac{\% \mathrm{Si}}{94} .
$$

As a complement of the Poliak and Jonas approach [14,29], Najafizadeh and Jonas [113] have proposed that the normalized true stress-strain curve $\left(\sigma / \sigma_{p}\right.$ vs. $\left.\varepsilon / \varepsilon_{p}\right)$ is suitable to apply the second derivative criterion [14,29] and the normalized strain hardening rate versus the normalized stress curve, $\partial\left(\sigma / \sigma_{\mathrm{p}}\right) / \partial\left(\varepsilon / \varepsilon_{\mathrm{p}}\right)$ versus $\sigma / \sigma_{\mathrm{p}}$, can be fitted using a third-order polynomial equation in order to determine the inflection points that identify the point of initiation of DRX in the range of temperature and strain rate of interest. Furthermore Najafizadeh and Jonas [113] showed that the critical stress and the critical strain ratio $R_{\sigma}=\frac{\sigma_{c}}{\sigma_{p}}$ and $R_{\varepsilon}$ are approximately constant and independent of the $Z$ parameter (see Figure 10). 

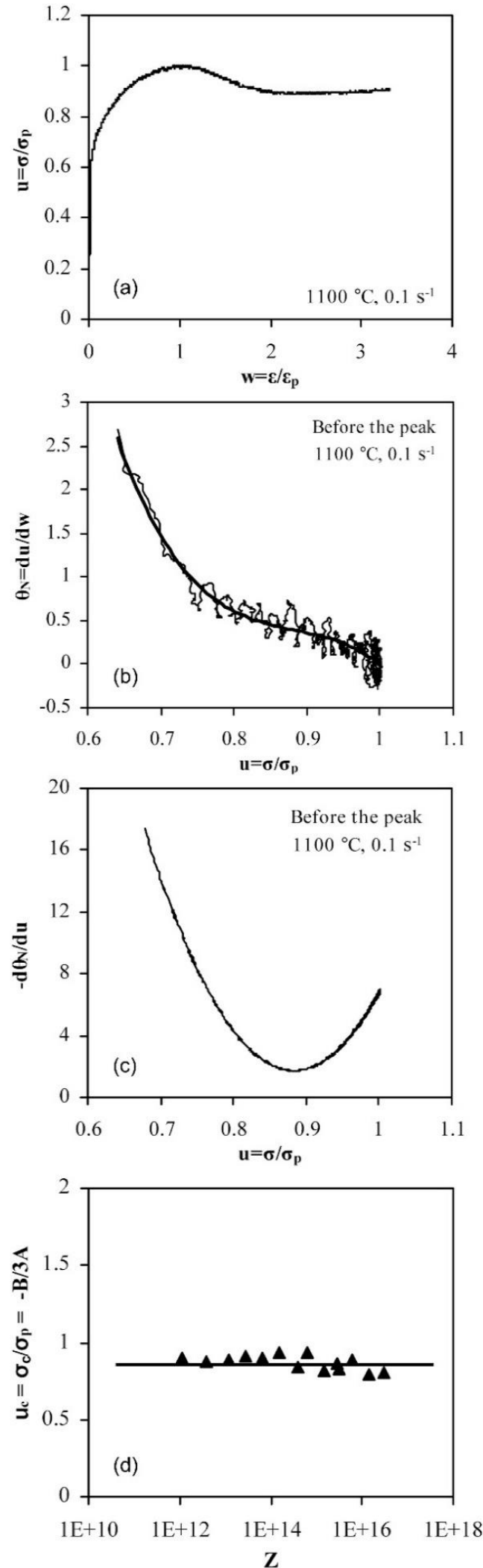

Figure 10. (a) Normalized stress-strain curve, (b) normalized strain hardening rate vs. normalized stress curve, (c) differentiation of normalized strain hardening rate vs. normalized stress curve, and (d) normalized critical stress ratio vs. the Zener-Hollomon parameter Z. Reprinted from ref [113] with permission from the Iron and Steel Institute of Japan (ISIJ). 


\section{Conclusions}

After a justificative introduction about the practical interest in deriving the onset for dynamic recrystallisation, a critical review is done on the different methods reported in the literature to derive the critical strain to initiate dynamic recrystallisation. These methods cover from metallographic procedures to several empirical and theoretical ways to obtain the associated strain to the onset of DRX. All methods are introduced, and main advantages and disadvantages aspects are outlined. Particular interest is paid to get the latter strain from constitutive equations.

Finally, a large review is done on all reported values for the critical strain for DRX in steels, particularly plain carbon or microalloyed steels. An attempt is also done to derive the effect of the chemical composition on the exponent of the classical relationship between the peak strain $\varepsilon_{\mathrm{p}}$ and the Zener-Hollomon parameter [30], by using a carbon equivalent parameter, considering also the type of testing conditions, whether compression, torsion, or tension.

Author Contributions: Conceptualization, G.V.-C. and J.-M.C.; investigation, G.V.-C.; writing-original draft preparation, G.V.-C. and J.-M.C.; writing-review and editing, J.-M.C. and J.-M.P.; supervision, J.-M.C.; funding acquisition, J.-M.C. and J.-M.P. All authors have read and agreed to the published version of the manuscript.

Funding: This work was financed by Ministerio de Fomento of Spain, through project No. 80032/A04.

Acknowledgments: One of the authors (Gonzalo Varela-Castro) is very grateful for the doctoral research grant provided by the Comissionat per a Universitats i Recerca del Departament d'Innovació, Universitats i Empresa de la Generalitat de Catalunya i del Fons Social Europeu (FI-2006). José-María Cabrera also thanks CONACyT (Mexico) for the financial support received in his sabbatical leaving.

Conflicts of Interest: The authors declare no conflict of interest.

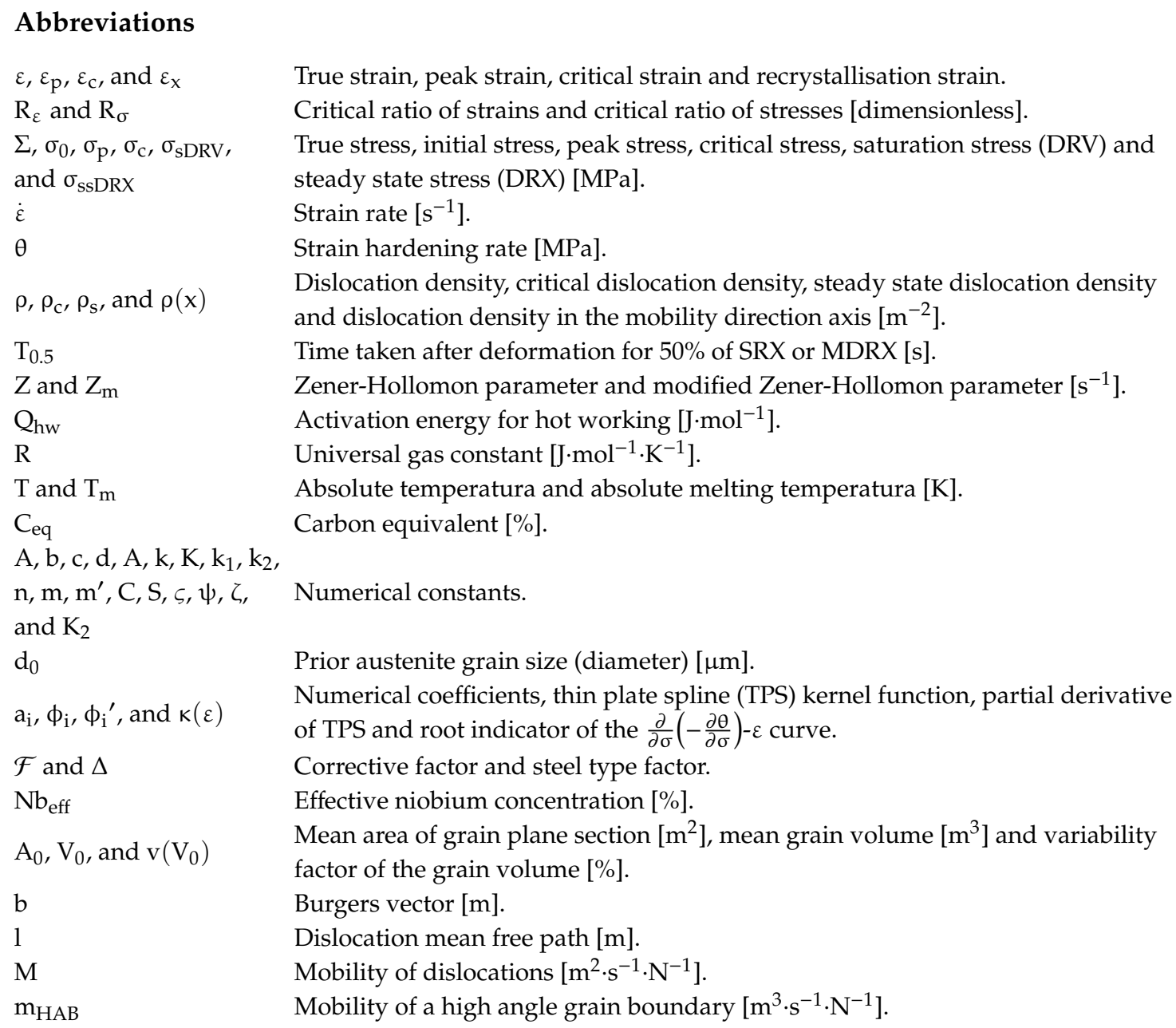


$\lambda$

3IVM

C, T, R, TE, and M dDRX

DRV

DRX

DT

EBSD

ESR

FFT

HAB

HSLA

IIW

KJMA

$\mathrm{MC}, \mathrm{CA}$, and PF

$\mathrm{PH}$

RBF

SDC

SFE

SRX

TEM

TPS

TRIP and TWIP steels $\mathrm{WH}$ or $\mathrm{SH}$
Energy per unit length of dislocation $\left[\mathrm{J} \cdot \mathrm{m}^{-1}\right]$.

Grain boundary energy per unit area $\left[\mathrm{J} \cdot \mathrm{m}^{-2}\right]$.

KJMA exponent.

Direction axis.

Regularization parameter.

Gamma-iron (austenite).

Pearson's coefficient.

Three Internal Variables Model.

Compression, torsion, rolling, tensión, and multiple techniques.

Discontinuous dynamic recrystallisation.

Dynamic recovery.

Dynamic recrystallisation.

Dynamic transformation.

Electron backscatter diffraction.

Electro-slag remelting.

Fast Fourier transform.

High angle grain boundaries.

High-strength low-alloy.

International Institute of Welding.

Kolmogorov-Johnson-Mehl-Avrami.

Monte Carlo, cellular autómata, and phase field.

Precipitation hardening stainless steel.

Radial basis function.

Second derivative criterion.

Stacking fault energy $\left[\mathrm{J} \cdot \mathrm{m}^{-2}\right]$.

Static recrystallisation.

Transmission electron microscopy.

Thin plate spline.

Transformation induced plasticity and twinning-induced plasticity steels.

Work hardening or strain hardening. 


\section{Appendix A}

Table A1. Literature collection of the reported values for the parameters for cited equations. See details in Section 2.2.

\begin{tabular}{|c|c|c|c|c|c|c|c|c|c|c|}
\hline Ref. & Chemical Composition * & Steel & Test $^{\dagger}$ & $d_{0} \ddagger$ & $Q_{h w} \S$ & $\kappa-K$ & $n$ & $m-m^{\prime}$ & $R_{\varepsilon}$ & Eqn. \\
\hline [32] & $0.17 \mathrm{C}, 1.35-1.36 \mathrm{Mn}, 0.31-0.36 \mathrm{Si}, 0.017-0.029 \mathrm{Al},(0.005) \mathrm{Ti},(0.04) \mathrm{Nb}$ & $\mathrm{Nb}$ & $\mathrm{T}$ & 300 & & & & & 0.86 & \\
\hline [141] & $0.17 \mathrm{C}, 1.35-1.36 \mathrm{Mn}, 0.31-0.36 \mathrm{Si}, 0.017-0.029 \mathrm{Al},(0.005) \mathrm{Ti},(0.04) \mathrm{Nb}$ & $\mathrm{Nb}$ HSLA & $\mathrm{T}$ & $<300$ & & & & & 0.67 & \\
\hline [33] & $\begin{array}{l}0.055-0.68 \mathrm{C},(0.44-1.64) \mathrm{Mn},(0.02-0.54) \mathrm{Si},(0.001-0.05) \mathrm{Al}, \\
(0.04-0.88) \mathrm{Cr},(0.012-0.24) \mathrm{Ni},(0.006-0.04) \mathrm{Mo},(0.005-0.03) \mathrm{Ti}, \\
(0.005-0.041) \mathrm{Nb},(0.02-0.15) \mathrm{V},(0.005) \mathrm{B}\end{array}$ & $\mathrm{CMn}$ & M & 50 & 312 & $4.90 \times 10^{-4}$ & 0.50 & 0.150 & & (1a) \\
\hline \multirow[t]{6}{*}{ [22] } & \multirow{6}{*}{$\begin{array}{l}0.06-0.9 \mathrm{C}, 1.32-1.56 \mathrm{Mn}, 0.22-0.75 \mathrm{Si}, 0.02-0.034 \mathrm{Al},(18.7) \mathrm{Cr} \text {, } \\
(9.07) \mathrm{Ni},(0.13-0.22) \mathrm{Mo},(0.017) \mathrm{Ti},(0.032-0.124) \mathrm{Nb}\end{array}$} & SiMn & $\mathrm{C}$ & $<360$ & 406 & & & & 0.80 & \\
\hline & & $\mathrm{Nb}$ & $\mathrm{C}$ & 270 & 402 & & & & 0.80 & \\
\hline & & $\mathrm{Nb}$ & $\mathrm{C}$ & 230 & & & & & 0.80 & \\
\hline & & $\mathrm{Nb}$ & $\mathrm{C}$ & 195 & 402 & & & & 0.80 & \\
\hline & & $\mathrm{Ti}$ & $\mathrm{C}$ & & & & & & 0.80 & \\
\hline & & $18-8$ & $\mathrm{C}$ & & 393 & & & & 0.80 & \\
\hline [142] & $\begin{array}{l}0.08-0.095 \mathrm{C}, 1.04-1.5 \mathrm{Mn}, 0.026-0.047 \mathrm{Si}, 0.09-0.15 \mathrm{Cr}, 0.08-0.18 \mathrm{Ni} \\
0.015-0.03 \mathrm{Mo}\end{array}$ & Low $\mathrm{C}$ & $\mathrm{T}$ & $<60$ & 310 & $5.38 \times 10^{-4}$ & 0.50 & 0.156 & 0.80 & (1a) \\
\hline$[71,143]$ & $0.0013-0.81 \mathrm{C}, 0.18-2.51 \mathrm{Mn}, 0.01-0.24 \mathrm{Si}, 0.019-0.066 \mathrm{Al}$ & $\mathrm{CMnSi}$ & $\mathrm{C}$ & $<160$ & & $4.76 \times 10^{-4}$ & & & & $(13 \mathrm{~b})$ \\
\hline [144] & $0.37 \mathrm{C}, 0.8 \mathrm{Mn}, 0.31 \mathrm{Si}, 0.03 \mathrm{Al}, 1.01 \mathrm{Cr}, 0.16 \mathrm{Ni}, 0.19 \mathrm{Mo}, 0.026 \mathrm{Ti}$ & Low alloy & $\mathrm{T}$ & $<50$ & 315 & $1.25 \times 10^{-4}$ & 0.75 & 0.183 & 0.78 & (1a) \\
\hline \multirow[t]{2}{*}{ [145] } & \multirow[t]{2}{*}{$0-0.37 \mathrm{C}, 0-0.8 \mathrm{Mn}, 0-0.31 \mathrm{Si}, 0-1.01 \mathrm{Cr}, 0-0.16 \mathrm{Ni}, 0-0.19 \mathrm{Mo}$} & Low $\mathrm{C}$ & $\mathrm{T}$ & & 300 & $4.10 \times 10^{-4}$ & 0.50 & 0.156 & 0.70 & (1a) \\
\hline & & Low alloy & $\mathrm{T}$ & & 300 & $9.60 \times 10^{-5}$ & 0.75 & 0.183 & 0.70 & (1a) \\
\hline [146] & Not reported & $\mathrm{CMn}$ & $\mathrm{R}$ & 100 & 312 & $6.97 \times 10^{-4}$ & 0.30 & 0.170 & 0.80 & (1a) \\
\hline$[76,78,109,122]$ & $\begin{array}{l}0.035-0.57 \mathrm{C}, 0.4-1.73 \mathrm{Mn}, 0.398-0.54 \mathrm{Si}, 0.8-18.65 \mathrm{Cr}, 0.5-14.44 \mathrm{Ni} \text {, } \\
0.06-3.64 \mathrm{Mo}\end{array}$ & AISI 304 & M & $<280$ & 400 & $4.50 \times 10^{-2}$ & 0.75 & 0.125 & & (1a) \\
\hline \multirow[t]{9}{*}[147,148]{} & & AISI 316 & M & 60 & 460 & $6.03 \times 10^{-1}$ & 0.75 & 0.053 & & (1a) \\
\hline & & AISI $301 \mathrm{~W}$ & $\mathrm{M}$ & 66 & 399 & & & & 0.66 & \\
\hline & & AISI 304C & $\mathrm{M}$ & 64 & 407 & & & & 0.71 & \\
\hline & & AISI 304W & M & $<280$ & 393 & & & & 0.61 & \\
\hline & & AISI 316C & $\mathrm{M}$ & 63 & 402 & & & & 0.66 & \\
\hline & & AISI 316W & $\mathrm{M}$ & 60 & 454 & & & & 0.64 & \\
\hline & & AISI 317C & $\mathrm{M}$ & 72 & 508 & & & & 0.72 & \\
\hline & & AISI 317W & M & 57 & 496 & & & & 0.65 & \\
\hline & & $\mathrm{FeC}$ & $\mathrm{T}$ & & 270 & & 0.50 & 0.100 & & (1a) \\
\hline$[149,150]$ & $0.065 \mathrm{C}, 0.65 \mathrm{Mn}, 0.03 \mathrm{Si}, 0.036 \mathrm{Al}, 0.066 \mathrm{Cr}, 0.009 \mathrm{Ni}, 0.001 \mathrm{Mo}, 0.028 \mathrm{Nb}$ & $\mathrm{Nb}$ & $\mathrm{T}$ & 30 & 450 & $1.47 \times 10^{-3}$ & 0.50 & 0.150 & 0.70 & (1a) \\
\hline
\end{tabular}


Table A1. Cont.

\begin{tabular}{|c|c|c|c|c|c|c|c|c|c|c|}
\hline Ref. & Chemical Composition * & Steel & Test $^{+}$ & $d_{0} \ddagger$ & $Q_{h w} \S$ & $\kappa-K$ & $n$ & $m-m^{\prime}$ & $R_{\varepsilon}$ & Eqn. \\
\hline$[43,151]$ & $0.03 \mathrm{C}, 1.54 \mathrm{Mn}, 0.19 \mathrm{Si}, 0.02 \mathrm{Al}, 0.02 \mathrm{Ti}$ & $\mathrm{CMn}$ & $\mathrm{C}$ & & 312 & $6.82 \times 10^{-3}$ & & 0.128 & & (1b) \\
\hline$[152,153]$ & Not reported & $\mathrm{CMn}$ & & & 312 & $3.68 \times 10^{-4}$ & 0.44 & 0.190 & & (1a) \\
\hline [74] & $0.13 \mathrm{C}, 1.55 \mathrm{Mn}, 0.28 \mathrm{Si}, 0.07 \mathrm{Al}, 0.23 \mathrm{Cr}, 0.33 \mathrm{Ni}, 0.028 \mathrm{Nb}, 0.049 \mathrm{~V}$ & $\mathrm{NbV}$ & $\mathrm{C}$ & & 464 & $4.56 \times 10^{-1}$ & & & & (14) \\
\hline \multirow[t]{2}{*}{ [154] } & $0.057-0.07 \mathrm{C}, 0.3-0.6 \mathrm{Mn}, 0.05-0.08 \mathrm{Si}, 0.011-0.017 \mathrm{Ni}, 0.005 \mathrm{Mo}$ & $\mathrm{CMn}$ & $\mathrm{T}$ & $<35$ & & $5.41 \times 10^{-4}$ & & 0.230 & 0.70 & (1b) \\
\hline & & $\mathrm{Nb}$ & $\mathrm{T}$ & & 307 & $7.51 \times 10^{-4}$ & & 0.230 & 0.70 & (1b) \\
\hline$[44,45]$ & $0.095-0.15 \mathrm{C}, 0.31-1.45 \mathrm{Mn}, 0.28-0.32 \mathrm{Si}, 0.015-0.038 \mathrm{Al}$ & CMn & C & $<350$ & 300 & & & 0.150 & & (3) \\
\hline \multirow[t]{4}{*}{ [155] } & $0.1-0.85 \mathrm{C}, 0.62-1.7 \mathrm{Mn}, 0.24-0.85 \mathrm{Si}, 0.005-0.03 \mathrm{Al}, 0.03-0.14 \mathrm{Cr}$ & ES17 & $\mathrm{T}$ & $<440$ & & $4.83 \times 10^{-3}$ & 0.09 & 0.150 & 0.85 & (1a) \\
\hline & & QC29B & $\mathrm{T}$ & & & $2.73 \times 10^{-3}$ & 0.20 & 0.150 & 0.85 & (1a) \\
\hline & & FP69 & $\mathrm{T}$ & & & $1.84 \times 10^{-3}$ & 0.24 & 0.150 & 0.85 & (1a) \\
\hline & & FF82 & $\mathrm{T}$ & & & $1.84 \times 10^{-3}$ & 0.24 & 0.150 & 0.85 & (1a) \\
\hline [73] & $0.11-0.17 \mathrm{C}, 0.89-1.51 \mathrm{Mn}, 0.03-0.3 \mathrm{Si}, 0.029-0.045 \mathrm{Al}$ & $\mathrm{C}$ & $\mathrm{C}$ & $<300$ & & $1.30 \times 10^{-5}$ & & & & $(13 b)$ \\
\hline [72] & $0.1 \mathrm{C}, 1.19 \mathrm{Mn}, 1 \mathrm{Si}, 1 \mathrm{Cr}$ & $\mathrm{CSiMnCr}$ & $\mathrm{M}$ & 80 & & $4.76 \times 10^{-4}$ & & & & $(13 b)$ \\
\hline \multirow[t]{2}{*}{ [156] } & $\begin{array}{l}0.1-0.19 \mathrm{C}, 1.26-1.7 \mathrm{Mn}, 0.24-0.36 \mathrm{Si}, 0.014-0.042 \mathrm{Al}, 0.01-0.012 \mathrm{Ti} \text {, } \\
0.04-0.15 \mathrm{~V}\end{array}$ & $\mathrm{Nb}$ & $\mathrm{T}$ & & & $9.38 \times 10^{-4}$ & & 0.230 & 0.80 & (1b) \\
\hline & & $\mathrm{V}$ & $\mathrm{T}$ & & 300 & $1.88 \times 10^{-2}$ & & 0.113 & 0.80 & $(1 b)$ \\
\hline \multirow[t]{6}{*}[157]{} & $\begin{array}{l}0.055-0.063 \mathrm{C}, 1.2-1.3 \mathrm{Mn}, 0.2-0.24 \mathrm{Si}, 0.029-0.036 \mathrm{Al}, 0.18 \mathrm{Mo} \\
0.02-0.16 \mathrm{Ti}\end{array}$ & MoTi & $\mathrm{T}$ & $<70$ & 296 & $5.24 \times 10^{-4}$ & 0.50 & 0.180 & 0.58 & (1a) \\
\hline & & $\mathrm{NbTi}$ & $\mathrm{T}$ & $<60$ & 375 & $2.80 \times 10^{-4}$ & 0.50 & 0.170 & 0.72 & (1a) \\
\hline & & $\mathrm{Ti}$ & $\mathrm{T}$ & $<90$ & 372 & $2.40 \times 10^{-4}$ & 0.50 & 0.180 & 0.80 & (1a) \\
\hline & & MoTi & $\mathrm{T}$ & & & $2.17 \times 10^{-3}$ & & 0.180 & & (1b) \\
\hline & & $\mathrm{NbTi}$ & $\mathrm{T}$ & & & $1.43 \times 10^{-3}$ & & 0.160 & & (1b) \\
\hline & & $\mathrm{Ti}$ & $\mathrm{T}$ & & & $1.50 \times 10^{-3}$ & & 0.170 & & (1b) \\
\hline \multirow[t]{6}{*}[58,59]{} & $0.163-1.06 \mathrm{C}, 0.35-1.55 \mathrm{Mn}, 0.13-0.31 \mathrm{Si}$ & 1041 & $\mathrm{~T}$ & 125 & 306 & $7.97 \times 10^{-4}$ & 0.50 & 0.157 & 0.70 & $(8)$ \\
\hline & & 9260 & $\mathrm{~T}$ & 88 & 311 & $4.17 \times 10^{-4}$ & 0.50 & 0.171 & 0.70 & (8) \\
\hline & & 52100 & $\mathrm{~T}$ & 150 & 303 & $7.45 \times 10^{-4}$ & 0.50 & 0.160 & 0.70 & (8) \\
\hline & & 10L60 & $\mathrm{T}$ & 90 & 351 & $6.51 \times 10^{-4}$ & 0.50 & 0.138 & 0.70 & (8) \\
\hline & & 32NiCrMoV12 & $\mathrm{T}$ & 180 & 387 & $7.06 \times 10^{-4}$ & 0.50 & 0.139 & 0.70 & (8) \\
\hline & & $15 \mathrm{NiCrMo} 16$ & $\mathrm{~T}$ & 44 & 414 & $4.87 \times 10^{-4}$ & 0.50 & 0.145 & 0.70 & (8) \\
\hline [158] & $0.04 \mathrm{C}, 0.4 \mathrm{Mn}, 0.3 \mathrm{Si}, 19.58 \mathrm{Cr}, 18.22 \mathrm{Ni}, 6.48 \mathrm{Mo}$ & High Mo & $\mathrm{C}$ & & 491 & & & 0.015 & & $(7 \mathrm{~b})$ \\
\hline \multirow[t]{2}{*}{ [159] } & $0.192-1.42 \mathrm{C}, 0.142-1.29 \mathrm{Mn}, 0.287-0.362 \mathrm{Si}$ & $\mathrm{CMn}$ & $\mathrm{T}$ & $<200$ & 248 & $4.30 \times 10^{-3}$ & 0.20 & 0.174 & 0.86 & (1a) \\
\hline & & $\mathrm{V}$ & $\mathrm{T}$ & $<140$ & 248 & $5.90 \times 10^{-3}$ & 0.20 & 0.172 & & (1a) \\
\hline
\end{tabular}


Table A1. Cont.

\begin{tabular}{|c|c|c|c|c|c|c|c|c|c|c|}
\hline Ref. & Chemical Composition * & Steel & Test $^{\dagger}$ & $d_{0} \ddagger$ & $Q_{h w} \S$ & $\kappa-K$ & $n$ & $m-m^{\prime}$ & $R_{\varepsilon}$ & Eqn. \\
\hline [160] & $0.157 \mathrm{C}, 1.4 \mathrm{Mn}, 0.45 \mathrm{Si}$ & $16 \mathrm{Mn}$ & $\mathrm{C}$ & & 392 & & & 0.050 & 0.83 & $(7 \mathrm{~b})$ \\
\hline [161] & Not reported & CMn-HSLA & $\mathrm{T}$ & & 300 & $6.50 \times 10^{-4}$ & 0.30 & 0.170 & 0.72 & (1a) \\
\hline [162] & $0.063 \mathrm{C}, 1.2 \mathrm{Mn}, 0.22 \mathrm{Si}, 0.029 \mathrm{Al}, 0.18 \mathrm{Mo}, 0.02 \mathrm{Ti}$ & MoTi & $\mathrm{T}$ & 50 & 295 & $7.07 \times 10^{-4}$ & 0.50 & 0.150 & & (1a) \\
\hline [163] & $0.078 \mathrm{C}, 1.39 \mathrm{Mn}, 0.35 \mathrm{Si}, 0.016 \mathrm{Al}$ & Mn & M & 140 & 245 & $4.90 \times 10^{-4}$ & 0.50 & 0.150 & 1.00 & (1a) \\
\hline [164] & $\begin{array}{l}0.046-0.09 \mathrm{C}, 1.2-1.57 \mathrm{Mn},(0.2-0.3) \mathrm{Si}, 0.031-0.05 \mathrm{Al}, 0.03-0.7 \mathrm{Ni} \text {, } \\
(0.1) \mathrm{Mo}, 0.001-0.142 \mathrm{Ti}, 0.011-0.046 \mathrm{Nb},(0.005-0.082) \mathrm{V}\end{array}$ & $\mathrm{Nb}$ & M & 40 & 375 & $2.84 \times 10^{-4}$ & 0.50 & 0.170 & 0.65 & (1a) \\
\hline [165] & $0.72 \mathrm{C}, 1.2 \mathrm{Mn}$ & S49 & $\mathrm{R}$ & $<500$ & & & & 0.150 & & (1a) \\
\hline [166] & $0.72 \mathrm{C}, 1.2 \mathrm{Mn}$ & $900 \mathrm{~A}$ & $\mathrm{C}$ & 220 & 315 & $4.05 \times 10^{-4}$ & 0.31 & 0.175 & 0.85 & (1a) \\
\hline [167] & $0.34 \mathrm{C}, 1.52 \mathrm{Mn}, 0.72 \mathrm{Si}, 0.0145 \mathrm{Al}, 0.0181 \mathrm{Ti}, 0.083 \mathrm{~V}$ & 38MnSiVS5 & $\mathrm{C}$ & $<120$ & 270 & $7.00 \times 10^{-3}$ & 0.15 & 0.137 & 1.00 & (1a) \\
\hline \multirow[t]{6}{*}{ [46-49] } & \multirow[t]{6}{*}{$\begin{array}{l}0.11-0.53 \mathrm{C}, 0.47-1.55 \mathrm{Mn}, 0.2-1.65 \mathrm{Si}, 0.18-0.38 \mathrm{Mo}, 0.021-0.075 \mathrm{Ti}, \\
0.041-0.093 \mathrm{Nb}, 0.043-0.093 \mathrm{~V}\end{array}$} & $\mathrm{CMn}$ & $\mathrm{T}$ & $<212$ & 275 & $9.52 \times 10^{-3}$ & 0.20 & 0.159 & 0.95 & (4a) \\
\hline & & $\mathrm{CSi}$ & $\mathrm{T}$ & $<143$ & 298 & $9.20 \times 10^{-2}$ & 0.20 & 0.161 & 0.95 & (4a) \\
\hline & & CMo & $\mathrm{T}$ & $<205$ & 285 & $1.18 \times 10^{-1}$ & 0.20 & 0.145 & 0.95 & (4a) \\
\hline & & $\mathrm{Ti}$ & $\mathrm{T}$ & $<95$ & 292 & $1.02 \times 10^{-1}$ & 0.20 & 0.170 & 0.95 & (4a) \\
\hline & & $\mathrm{V}$ & $\mathrm{T}$ & $<172$ & 278 & $9.88 \times 10^{-2}$ & 0.20 & 0.166 & 0.95 & (4a) \\
\hline & & $\mathrm{Nb}$ & $\mathrm{T}$ & $<122$ & 291 & $9.60 \times 10^{-2}$ & 0.20 & 0.219 & 0.95 & (4a) \\
\hline [168] & Not reported & Plain C & $\mathrm{R}$ & 300 & 300 & $5.60 \times 10^{-4}$ & 0.03 & 0.170 & & (1a) \\
\hline$[52]$ & $0.03-0.1 \mathrm{C}, 0.24-1.08 \mathrm{Mn}, 0.002-0.06 \mathrm{Si}, 0.02-0.047 \mathrm{Al}$ & $\mathrm{CMn}$ & $\mathrm{M}$ & 100 & 300 & $5.60 \times 10^{-4}$ & 0.30 & 0.170 & & (1a) \\
\hline$[52]$ & Not reported & $\mathrm{Nb}$ & $\mathrm{M}$ & & 375 & $2.80 \times 10^{-4}$ & 0.50 & 0.170 & 0.60 & (6) \\
\hline [169] & $0.03-0.3 \mathrm{C}, 0.2-1.7 \mathrm{Mn}, 0-0.6 \mathrm{Si}$ & Low $\mathrm{C}$ & $\mathrm{C}$ & $<250$ & 305 & $6.97 \times 10^{-4}$ & 0.90 & 0.170 & 0.70 & (1a) \\
\hline [170] & $0.71-0.75 \mathrm{C}, 1.12-1.2 \mathrm{Mn}, 0.2-0.4 \mathrm{Si},(0.01) \mathrm{Al}, 0.07-0.1 \mathrm{Cr}$ & $900 \mathrm{~A}$ & $\mathrm{C}$ & 210 & 315 & $4.50 \times 10^{-4}$ & 0.33 & 0.180 & 0.95 & (1a) \\
\hline [171] & $0.156-0.176 \mathrm{C}, 0.56-1.28 \mathrm{Mn}, 0.015-0.056 \mathrm{Si}, 0.021 \mathrm{Al}$ & Low $\mathrm{C}$ & & $<180$ & & $1.43 \times 10^{-5}$ & & 0.220 & & $(13)$ \\
\hline \multirow[t]{2}{*}{ [62] } & \multirow[t]{2}{*}{$\begin{array}{l}0.04-0.17 \mathrm{C}, 0.3-0.74 \mathrm{Mn}, 0.009-0.012 \mathrm{Si}, 0.04 \mathrm{Al}, 0.019-0.033 \mathrm{Cr}, \\
0.01-0.025 \mathrm{Ni}\end{array}$} & \multirow[t]{2}{*}{ Plain C } & $\mathrm{C}$ & $<244$ & 334 & $1.32 \times 10^{-2}$ & 0.17 & 0.165 & 0.83 & (11b) \\
\hline & & & $\mathrm{C}$ & & 334 & $1.32 \times 10^{-2}$ & 0.17 & 0.165 & & (11b) \\
\hline$[136,172]$ & $0.34 \mathrm{C}, 1.52 \mathrm{Mn}, 0.72 \mathrm{Si}, 0.0145 \mathrm{Al}, 0.018 \mathrm{Ti}, 0.083 \mathrm{~V}$ & 38MnSiVS5 & $\mathrm{C}$ & $<120$ & 270 & $7.00 \times 10^{-3}$ & 0.15 & 0.140 & 0.80 & (1a) \\
\hline \multirow[t]{4}{*}{ [108] } & \multirow[t]{4}{*}{$\begin{array}{l}0.28-0.47 \mathrm{C}, 0.52-0.76 \mathrm{Mn},(0.83-1.38) \mathrm{Cr},(0.46) \mathrm{Ni},(0.15-0.97) \mathrm{Mo}, \\
(0.016) \mathrm{Nb},(0.12-0.27) \mathrm{V}\end{array}$} & Base & $\mathrm{T}$ & & 147 & & 0.50 & 0.170 & & (1a) \\
\hline & & CrMo & $\mathrm{T}$ & & 191 & & 0.50 & 0.190 & & (1a) \\
\hline & & $\mathrm{CrMoV}$ & $\mathrm{T}$ & & 236 & & 0.50 & 0.160 & & (1a) \\
\hline & & $\mathrm{CrMoVNb}$ & $\mathrm{T}$ & & 241 & $4.00 \times 10^{-3}$ & 0.50 & 0.170 & 0.84 & (1a) \\
\hline
\end{tabular}


Table A1. Cont.

\begin{tabular}{|c|c|c|c|c|c|c|c|c|c|c|}
\hline Ref. & Chemical Composition * & Steel & Test $^{\dagger}$ & $d_{0} \ddagger$ & $Q_{h w} \S$ & $\kappa-K$ & $n$ & $m-m^{\prime}$ & $R_{\varepsilon}$ & Eqn. \\
\hline$[132,173]$ & $\begin{array}{l}0.0037-0.79 \mathrm{C}, 0.32-1.69 \mathrm{Mn}, 0.003-0.005 \mathrm{Cr}, 0.003-0.008 \mathrm{Ni} \text {, } \\
0.002-0.003 \mathrm{Mo}, 0.003 \mathrm{~V}\end{array}$ & $\mathrm{C}$ & $\mathrm{T}$ & 100 & 294 & & & & 1.00 & \\
\hline$[28,174]$ & $\begin{array}{l}0.05-0.14 \mathrm{C}, 0.002-0.325 \mathrm{Mn}, 0.35-1.33 \mathrm{Si}, 0.019-0.057 \mathrm{Al}, \\
(0.016-0.024) \mathrm{Ti}, 0.008-0.08 \mathrm{Nb}\end{array}$ & $\mathrm{Nb}$ & M & 100 & 375 & $2.80 \times 10^{-4}$ & 0.50 & 0.170 & 0.61 & (6) \\
\hline [175] & Not reported & TMS-80R & $\mathrm{C}$ & $<250$ & 280 & $1.20 \times 10^{-3}$ & 0.27 & 0.180 & 0.83 & (1a) \\
\hline [176] & $0.1 \mathrm{C}, 0.45 \mathrm{Mn}, 0.35 \mathrm{Si}, 0.5 \mathrm{Cr}, 0.4 \mathrm{Ni}, 0.3 \mathrm{Mo}, 0.085 \mathrm{Ti}, 0.04 \mathrm{Nb}, 0.06 \mathrm{~V}$ & $\mathrm{~V}$ & $\mathrm{M}$ & $<100$ & 300 & & 0.50 & 0.170 & & (1a) \\
\hline \multirow[t]{3}{*}{ [51] } & $0.003-0.005 \mathrm{C}, 0.22 \mathrm{Mn}, 0.02 \mathrm{Si}, 0.005-0.013 \mathrm{Al}, 0.009-0.08 \mathrm{Ti}$ & ULow $\mathrm{C}$ & $\mathrm{C}$ & & & $1.70 \times 10^{-4}$ & & 0.417 & & (5) \\
\hline & & ULow C & $\mathrm{C}$ & & & $1.09 \times 10^{-4}$ & & 0.190 & & (5) \\
\hline & & CMn & $\mathrm{C}$ & & & $1.17 \times 10^{-4}$ & & 0.401 & & (5) \\
\hline \multirow[t]{2}{*}{ [177] } & $0.07-0.1 \mathrm{C}, 0.15-1.52 \mathrm{Mn}, 0.11-0.43 \mathrm{Si},(0.054) \mathrm{Al},(0.03) \mathrm{Nb},(0.1) \mathrm{V}$ & HSLA & $\mathrm{M}$ & & 306 & $1.30 \times 10^{-3}$ & & 0.180 & & (1b) \\
\hline & & HSLA & M & & 405 & $9.00 \times 10^{-4}$ & & 0.160 & & (1b) \\
\hline$[178,179]$ & $0.03 \mathrm{C}, 0.8 \mathrm{Mn}, 0.8 \mathrm{Si}, 20 \mathrm{Cr}, 18.775 \mathrm{Ni}, 5.75 \mathrm{Mo}$ & High Mo & $\mathrm{C}$ & & 587 & $1.84 \times 10^{-4}$ & & 0.128 & & (1b) \\
\hline$[50,180]$ & $0.054 \mathrm{C}, 1.04 \mathrm{Mn}, 0.59 \mathrm{Si}, 18.25 \mathrm{Cr}, 8.16 \mathrm{Ni}, 0.15 \mathrm{Mo}$ & AISI 304 & $\mathrm{~T}$ & 100 & 380 & $3.70 \times 10^{-1}$ & & 0.012 & 0.73 & $(4 \mathrm{~b})$ \\
\hline [181] & $0.085 \mathrm{C}, 0.95 \mathrm{Mn}, 0.29 \mathrm{Si}, 0.025 \mathrm{Al}, 0.045 \mathrm{Nb}$ & $\mathrm{Nb}$ & $\mathrm{T}$ & & 314 & & & 0.190 & & (1a) \\
\hline \multirow[t]{7}{*}{ [182] } & $0.067-0.074 \mathrm{C}, 1.47-1.51 \mathrm{Mn}, 0.202-0.207 \mathrm{Si},(0.304-0.606) \mathrm{Cr}$ & $\mathrm{Nb}$ & $\mathrm{T}$ & & 340 & $6.90 \times 10^{-4}$ & 0.50 & 0.250 & & (1a) \\
\hline & $(0.2-0.496) \mathrm{Ni}, 0.151-0.283 \mathrm{Mo}, 0.014-0.015 \mathrm{Ti}, 0.032-0.062 \mathrm{Nb}$ & $\mathrm{Nb}$ & $\mathrm{T}$ & & 377 & $1.80 \times 10^{-3}$ & 0.50 & 0.110 & & (1a) \\
\hline & & $\mathrm{Nb}$ & $\mathrm{T}$ & & 359 & $1.30 \times 10^{-3}$ & 0.50 & 0.130 & & (1a) \\
\hline & & $\mathrm{Nb}$ & $\mathrm{T}$ & & 354 & $1.20 \times 10^{-3}$ & 0.50 & 0.100 & & (1a) \\
\hline & & $\mathrm{Nb}$ & $\mathrm{T}$ & & 324 & $1.10 \times 10^{-3}$ & 0.50 & 0.130 & & (1a) \\
\hline & & $\mathrm{Nb}$ & $\mathrm{T}$ & & 287 & $8.30 \times 10^{-4}$ & 0.50 & 0.170 & & (1a) \\
\hline & & $\mathrm{Nb}$ & $\mathrm{T}$ & & 316 & $5.80 \times 10^{-4}$ & 0.50 & 0.160 & & (1a) \\
\hline \multirow[t]{2}{*}{ [183] } & $0.84-1 \mathrm{C}, 0.25-0.7 \mathrm{Mn}, 0.3 \mathrm{Si}, 4-5 \mathrm{Cr}, 1.15-5 \mathrm{Mo}, 0.3-1.9 \mathrm{~V}$ & $\mathrm{~A} 2$ & $\mathrm{~T}$ & 143 & 399 & & & & 0.65 & \\
\hline & & M2 & $\mathrm{T}$ & 90 & 455 & & & & 0.65 & \\
\hline$[61]$ & Not reported & Low $\mathrm{C}$ & $\mathrm{R}$ & & 312 & $8.03 \times 10^{-4}$ & 0.17 & 0.177 & & (10) \\
\hline \multirow[t]{2}{*}{ [184-186] } & $18.25 \mathrm{Cr}, 8.16 \mathrm{Ni}$ & AISI 304 & $\mathrm{C}$ & $<45$ & 380 & $3.00 \times 10^{-3}$ & 0.50 & 0.090 & 0.73 & (1a) \\
\hline & & & & & & $2.20 \times 10^{-3}$ & 0.50 & 0.089 & & (1a) \\
\hline [187] & $0.01 \mathrm{C}, 0.057 \mathrm{Mn}$ & ARMCO & $\mathrm{C}$ & & 270 & $4.80 \times 10^{-3}$ & & 0.145 & & (1b) \\
\hline \multirow[t]{2}{*}[188,189]{} & $0.02-0.087 \mathrm{C}, 1.48-1.58 \mathrm{Mn}, 0.42 \mathrm{Si}, 0.0048-0.0069 \mathrm{Al}, 18.42-18.82 \mathrm{Cr}$, & AISI 304L & C & 29 & & $1.50 \times 10^{-2}$ & & 0.156 & 0.80 & (1b) \\
\hline & $8.19-8.97 \mathrm{Ni}, 0.25-0.36 \mathrm{Mo}, 0.01-0.03 \mathrm{Nb}, 0.08-0.09 \mathrm{~V}$ & AISI $304 \mathrm{H}$ & $\mathrm{C}$ & 42 & & $1.90 \times 10^{-2}$ & & 0.144 & 0.80 & (1b) \\
\hline \multirow[t]{2}{*}{ [190] } & $\begin{array}{l}0.026-0.032 \mathrm{C}, 1.03-1.05 \mathrm{Mn}, 0.21-0.22 \mathrm{Si},(0.02) \mathrm{Al}, 0.088-0.106 \mathrm{Ti}, \\
0.098-0.099 \mathrm{~V}\end{array}$ & $\begin{array}{l}\text { HSLA RH } \\
\text { free }\end{array}$ & C & & 270 & $3.70 \times 10^{-3}$ & & 0.190 & & (1b) \\
\hline & & HSLA RH & $\mathrm{C}$ & & 270 & $4.00 \times 10^{-3}$ & & 0.200 & & (1b) \\
\hline
\end{tabular}


Table A1. Cont.

\begin{tabular}{|c|c|c|c|c|c|c|c|c|c|c|}
\hline Ref. & Chemical Composition * & Steel & Test $^{\dagger}$ & $d_{0} \ddagger$ & $Q_{h w} \S$ & $\kappa-K$ & $n$ & $m-m^{\prime}$ & $R_{\varepsilon}$ & Eqn. \\
\hline [191] & $0.0028 \mathrm{C}, 0.15 \mathrm{Mn}, 0.01 \mathrm{Si}, 0.058 \mathrm{Al}, 0.083 \mathrm{Ti}$ & IF & $\mathrm{T}$ & & 342 & $1.22 \times 10^{-2}$ & & 0.120 & & $(1 \mathrm{~b})$ \\
\hline \multirow{3}{*}[192-195]{} & $0.01-0.7 \mathrm{C}, 0.55-0.7 \mathrm{Mn}, 0.05-1.1 \mathrm{Si}, 0.05-0.08 \mathrm{Cr},(0.0005-0.0015) \mathrm{B}$ & Low $\mathrm{C}$ & $\mathrm{C}$ & 160 & 338 & $6.50 \times 10^{-4}$ & 0.43 & 0.132 & 0.80 & (1a) \\
\hline & & High C & C & 90 & 316 & $2.50 \times 10^{-3}$ & 0.40 & 0.090 & 0.80 & (1a) \\
\hline & & High Si & $\mathrm{C}$ & $<240$ & 440 & $4.20 \times 10^{-4}$ & 0.40 & 0.120 & 0.80 & (1a) \\
\hline [196-198] & $0.4 \mathrm{C}, 0.7 \mathrm{Mn}, 0.2 \mathrm{Si}, 1 \mathrm{Cr}, 0.15 \mathrm{Mo}$ & AISI 4140 & $\mathrm{~T}$ & 140 & 318 & $3.88 \times 10^{-1}$ & & 0.158 & 0.65 & $(4 b)$ \\
\hline \multirow[t]{3}{*}{ [199] } & $0.085-0.087 \mathrm{C}, 0.52-1.5 \mathrm{Mn}, 0.27-0.3 \mathrm{Si}, 0.025-0.029 \mathrm{Al}, 0.045-0.05 \mathrm{Nb}$ & $\mathrm{Nb}$ & $\mathrm{T}$ & & 370 & $8.90 \times 10^{-5}$ & 0.50 & 0.190 & & (1a) \\
\hline & & $\mathrm{Nb}$ & $\mathrm{T}$ & & 314 & $3.00 \times 10^{-5}$ & 0.50 & 0.190 & & (1a) \\
\hline & & $\mathrm{Nb}$ & $\mathrm{T}$ & & 286 & $4.60 \times 10^{-5}$ & 0.50 & 0.190 & & (1a) \\
\hline \multirow[t]{4}{*}{ [200] } & $0.08-0.14 \mathrm{C}, 1.2-1.6 \mathrm{Mn}, 0.28-0.4 \mathrm{Si}, 0.015-0.022 \mathrm{Al}, 0.56-0.67 \mathrm{Mo}$ & Mo & $\mathrm{C}$ & 161 & 400 & $3.98 \times 10^{-2}$ & 0.20 & 0.120 & & (4a) \\
\hline & & $\mathrm{MoNb}$ & $\mathrm{C}$ & 179 & 343 & $2.81 \times 10^{-2}$ & 0.20 & 0.220 & & (4a) \\
\hline & & $\mathrm{MoV}$ & C & 172 & 330 & $5.52 \times 10^{-2}$ & 0.20 & 0.145 & & (4a) \\
\hline & & MoTi & C & 129 & 400 & $3.93 \times 10^{-2}$ & 0.20 & 0.133 & & (4a) \\
\hline \multirow[t]{3}{*}{$\begin{array}{r}{[29,111,201} \\
202]\end{array}$} & $\begin{array}{l}0.04-0.08 \mathrm{C}, 0.22-1.95 \mathrm{Mn}, 0.012-1.09 \mathrm{Si},(0.05-0.06) \mathrm{Al},(18.56) \mathrm{Cr} \text {, } \\
(9.1) \mathrm{Ni},(0.03) \mathrm{Nb}\end{array}$ & AK & $\mathrm{C}$ & & 265 & $2.51 \times 10^{-3}$ & & 0.190 & 0.52 & (1b) \\
\hline & & $\mathrm{Nb}$ & C & & 319 & & & 0.090 & 0.55 & (1a) \\
\hline & & AISI 321 & C & & & & & & 0.60 & \\
\hline$[53,203]$ & $\begin{array}{l}\text { 0.07-0.1C, } 0.62-1.42 \mathrm{Mn}, 0.01-0.31 \mathrm{Si}, 0.039-0.053 \mathrm{Al},(0.02) \mathrm{Cr} \text {, } \\
(0.02) \mathrm{Ni}, 0.005-0.067 \mathrm{Ti}, 0.034-0.035 \mathrm{Nb}\end{array}$ & $\mathrm{Nb}-\mathrm{NbTi}$ & $\mathrm{T}$ & $<805$ & 325 & $3.70 \times 10^{-3}$ & 0.15 & 0.155 & 0.77 & (6) \\
\hline \multirow[t]{7}{*}{ [204] } & $(0.0005-0.07) \mathrm{C},(1.51-1.58) \mathrm{Mn},(18-18.5) \mathrm{Cr},(8.2-12.2) \mathrm{Ni}$ & AISI 304L & $\mathrm{C}$ & 18 & 280 & $1.50 \times 10^{-2}$ & & 0.156 & 1.00 & (1b) \\
\hline & & AISI $304 \mathrm{H}$ & $\mathrm{C}$ & 21 & 280 & $1.90 \times 10^{-2}$ & & 0.144 & 1.00 & (1b) \\
\hline & & $\mathrm{HP}$ & C & 10 & 280 & $3.23 \times 10^{-3}$ & 0.48 & 0.143 & 1.00 & (1a) \\
\hline & & $\mathrm{HP}$ & $\mathrm{C}$ & 24 & 280 & $3.23 \times 10^{-3}$ & 0.48 & 0.139 & 1.00 & (1a) \\
\hline & & $\mathrm{HP}$ & $\mathrm{C}$ & 92 & 280 & $3.23 \times 10^{-3}$ & 0.48 & 0.148 & 1.00 & (1a) \\
\hline & & UHP & $\mathrm{C}$ & 20 & 280 & $3.61 \times 10^{-3}$ & 0.53 & 0.131 & 1.00 & (1a) \\
\hline & & UHP & $\mathrm{C}$ & 135 & 280 & $3.61 \times 10^{-3}$ & 0.53 & 0.182 & 1.00 & (1a) \\
\hline [205] & $0.18 \mathrm{C}, 0.6 \mathrm{Mn}, 0.22 \mathrm{Si}$ & Q235 & $\mathrm{C}$ & $<400$ & 363 & $4.37 \times 10^{-4}$ & 0.21 & 0.168 & 0.83 & (1a) \\
\hline \multirow[t]{4}{*}[54,164]{} & $\begin{array}{l}0.71-1.1 \mathrm{C}, 0.63-0.77 \mathrm{Mn}, 0.22-0.99 \mathrm{Si}, 0.04-0.066 \mathrm{Cr}, 0.038-0.07 \mathrm{Ni} \text {, } \\
(0.078-0.66 \mathrm{~V}\end{array}$ & $\mathrm{V}$ & $\mathrm{C}$ & 94 & 282 & $9.36 \times 10^{-4}$ & 0.50 & 0.150 & & (6) \\
\hline & & $\mathrm{V}$ & $\mathrm{C}$ & 92 & 280 & $7.96 \times 10^{-4}$ & 0.50 & 0.150 & & \\
\hline & & $\mathrm{V}$ & C & 97 & 287 & $9.70 \times 10^{-4}$ & 0.50 & 0.150 & & \\
\hline & & $\mathrm{CMn}$ & $\mathrm{C}$ & 105 & 250 & $7.90 \times 10^{-4}$ & 0.50 & 0.160 & & \\
\hline [206] & $0.45 \mathrm{C}, 1.2 \mathrm{Mn}, 0.6 \mathrm{Si}, 0.12 \mathrm{Cr}, 0.017 \mathrm{Ti}, 0.1 \mathrm{~V}$ & Med. CV & $\mathrm{T}$ & 120 & 296 & $3.80 \times 10^{-1}$ & & 0.157 & 0.62 & (4b) \\
\hline [207] & Not reported & CMn & $\mathrm{T}$ & 300 & 300 & $6.97 \times 10^{-4}$ & 0.30 & 0.170 & 0.81 & (1a) \\
\hline
\end{tabular}


Table A1. Cont.

\begin{tabular}{|c|c|c|c|c|c|c|c|c|c|c|}
\hline Ref. & Chemical Composition * & Steel & Test $^{+}$ & $d_{0} \ddagger$ & $Q_{h w}{ }^{\S}$ & $\kappa-K$ & $n$ & $m-m^{\prime}$ & $\boldsymbol{R}_{\varepsilon}$ & Eqn. \\
\hline [208] & $0.004 \mathrm{C}, 0.132 \mathrm{Mn}, 0.011 \mathrm{Si}, 0.011 \mathrm{Al}, 0.065 \mathrm{Ti}$ & ULow C & $\mathrm{T}$ & & 297 & & & 0.095 & & $(7 b)$ \\
\hline [209] & Not reported & AISI 316 & $\mathrm{~T}$ & 90 & 414 & $2.40 \times 10^{-1}$ & & 0.057 & & (4b) \\
\hline \multirow[t]{2}{*}{ [133] } & \multirow[t]{2}{*}{$\begin{array}{l}0.06-0.5 \mathrm{C}, 0.42-0.68 \mathrm{Mn}, 0.12-0.2 \mathrm{Si},(0.003) \mathrm{Al}, 0.01-0.04 \mathrm{Cr}, 0.07 \mathrm{Ni} \text {, } \\
(0.015) \mathrm{Mo}, 0.002 \mathrm{~V}\end{array}$} & Low C & $\mathrm{C}$ & 53 & 270 & $4.80 \times 10^{-3}$ & & 0.170 & 1.00 & $(1 b)$ \\
\hline & & High C & $\mathrm{C}$ & 78 & 270 & $1.10 \times 10^{-2}$ & & 0.130 & 1.00 & (1b) \\
\hline [210] & $0.155 \mathrm{C}, 0.45 \mathrm{Mn}$ & AISI 1015 & $\mathrm{C}$ & & & $1.76 \times 10^{-4}$ & & & & $(13 b)$ \\
\hline [211] & $0.18 \mathrm{C}, 0.87 \mathrm{Mn}, 0.25 \mathrm{Si}$ & BS430 & $\mathrm{C}$ & & 280 & $8.76 \times 10^{-3}$ & & 0.166 & 0.12 & $(1 \mathrm{~b})$ \\
\hline [212] & $0.38 \mathrm{C}, 0.5 \mathrm{Mn}, 0.2 \mathrm{Si}, 0.86 \mathrm{Cr}, 0.2 \mathrm{Mo}$ & 35CrMo & $\mathrm{C}$ & $<150$ & 378 & $3.52 \times 10^{-3}$ & & 0.138 & 0.83 & (1b) \\
\hline \multirow[t]{2}{*}{ [213] } & \multirow[t]{2}{*}{$\begin{array}{l}0.038 \mathrm{C}, 0.25 \mathrm{Mn}, 0.02 \mathrm{Si}, 0.045 \mathrm{Al}, 0.008 \mathrm{Cr}, 0.001 \mathrm{Ni}, 0.001 \mathrm{Mo}, 0.001 \mathrm{Ti}, \\
0.002 \mathrm{Nb}, 0.007 \mathrm{~V}\end{array}$} & \multirow[t]{2}{*}{ SAE 1006} & $\mathrm{C}$ & 26 & 333 & $1.30 \times 10^{-4}$ & 0.30 & 0.200 & 0.80 & (1a) \\
\hline & & & C & 277 & 238 & $6.20 \times 10^{-4}$ & 0.30 & 0.220 & 0.80 & (1a) \\
\hline$[26,214]$ & $0.072 \mathrm{C}, 1.08 \mathrm{Mn}, 0.57 \mathrm{Si}, 18.41 \mathrm{Cr}, 8.21 \mathrm{Ni}$ & AISI 304 & $\mathrm{C}$ & $<100$ & 405 & & & & 0.51 & \\
\hline \multirow[t]{3}{*}[215,216]{} & \multirow[t]{3}{*}{$\begin{array}{l}0.004-0.4 \mathrm{C}, 0.84-1 \mathrm{Mn},(0.24) \mathrm{Si}, 0.021-0.035 \mathrm{Al},(0.02) \mathrm{Cr},(0.01) \mathrm{Ni} \text {, } \\
(0.02) \mathrm{Ti},(0.04) \mathrm{Nb},(0.001) \mathrm{B}\end{array}$} & Med. C & $\mathrm{T}$ & 88 & & & & & 0.56 & \\
\hline & & IF & $\mathrm{T}$ & 55 & 300 & & & & 0.75 & \\
\hline & & IF & $\mathrm{T}$ & 200 & 340 & & & & 0.75 & \\
\hline \multirow[t]{2}{*}{ [217] } & \multirow[t]{2}{*}{$0.71-0.91 \mathrm{C}, 0.49-0.68 \mathrm{Mn}, 0.21-0.22 \mathrm{Si}, 0.04-0.05 \mathrm{Cr}$} & Hypo. & $\mathrm{C}$ & 98 & 317 & & & & 0.55 & \\
\hline & & Hyper. & $\mathrm{C}$ & 112 & 290 & & & & 0.51 & \\
\hline \multirow[t]{4}{*}{ [218] } & \multirow{4}{*}{$\begin{array}{l}0.038-0.051 \mathrm{C}, 0.224-0.25 \mathrm{Mn}, 0.014-0.02 \mathrm{Si}, 0.045-0.05 \mathrm{Al}, \\
0.008-0.027 \mathrm{Cr}, 0.001-0.011 \mathrm{Ni}, 0.001 \mathrm{Mo}, 0.001-0.002 \mathrm{Ti}, \\
0.001-0.002 \mathrm{Nb}, 0.002-0.007 \mathrm{~V},(0.0004) \mathrm{B}\end{array}$} & VDB cast & $\mathrm{C}$ & 124 & 309 & $3.27 \times 10^{-4}$ & 0.30 & 0.180 & 0.80 & (1a) \\
\hline & & SS cast & $\mathrm{C}$ & 277 & 238 & $6.20 \times 10^{-4}$ & 0.30 & 0.220 & 0.80 & (1a) \\
\hline & & VDB roll. & $\mathrm{C}$ & 50 & 388 & $3.90 \times 10^{-4}$ & 0.30 & 0.145 & 0.80 & (1a) \\
\hline & & SS roll. & $\mathrm{C}$ & 26 & 333 & $1.30 \times 10^{-4}$ & 0.30 & 0.200 & 0.80 & (1a) \\
\hline \multirow[t]{3}{*}{ [219] } & \multirow[t]{3}{*}{$0.18-0.24 \mathrm{C}, 0.65-0.82 \mathrm{Mn}, 0.01-0.51 \mathrm{Si}, 0.005-0.009 \mathrm{Al}$} & CSiMn & $\mathrm{C}$ & 80 & 270 & $7.58 \times 10^{-3}$ & & 0.140 & & (1b) \\
\hline & & CSiMn & $\mathrm{C}$ & 109 & 270 & $8.83 \times 10^{-3}$ & & 0.140 & & (1b) \\
\hline & & CSiMn & $\mathrm{C}$ & 101 & 270 & $1.01 \times 10^{-2}$ & & 0.140 & & (1b) \\
\hline$[220,221]$ & $0.23 \mathrm{C}, 0.74 \mathrm{Mn}, 0.22 \mathrm{Si}, 0.031 \mathrm{Al}, 0.9 \mathrm{Cr}, 0.05 \mathrm{Ni}, 0.08 \mathrm{Mo}$ & $\mathrm{MnCr}$ & C & $<150$ & 379 & $5.24 \times 10^{-5}$ & 0.50 & 0.188 & 0.80 & (1a) \\
\hline \multirow[t]{3}{*}{ [222] } & \multirow{3}{*}{$0.004 \mathrm{C}, 1.1 \mathrm{Mn}, 0.02 \mathrm{Ti}, 0.04 \mathrm{Nb},(0.0005-0.001) \mathrm{B}$} & IF & $\mathrm{C}$ & & 362 & & & & 0.79 & \\
\hline & & & & & 364 & & & & 0.80 & \\
\hline & & & & & 404 & & & & 0.82 & \\
\hline [223] & $0.55 \mathrm{C}, 0.78 \mathrm{Mn}, 0.31 \mathrm{Si}, 0.76 \mathrm{Cr}, 0.07 \mathrm{Ni}, 0.02 \mathrm{Mo}$ & DIN55Cr3 & $\mathrm{C}$ & 34 & 340 & $3.36 \times 10^{-4}$ & 0.50 & 0.150 & & (1a) \\
\hline [224] & Not reported & Eutectoid & $\mathrm{R}$ & $<50$ & & $4.50 \times 10^{-4}$ & 0.33 & 0.180 & 0.90 & (1a) \\
\hline
\end{tabular}


Table A1. Cont.

\begin{tabular}{|c|c|c|c|c|c|c|c|c|c|c|}
\hline Ref. & Chemical Composition * & Steel & Test $^{+}$ & $d_{0} \ddagger$ & $Q_{h w} \S$ & $\kappa-K$ & $n$ & $m-m^{\prime}$ & $\boldsymbol{R}_{\varepsilon}$ & Eqn \\
\hline$[225]$ & $0.08 \mathrm{C}, 1.2 \mathrm{Mn}, 0.6 \mathrm{Si}, 18.3 \mathrm{Cr}, 8.4 \mathrm{Ni}$ & AISI 304 & $\mathrm{~T}$ & & 401 & $3.78 \times 10^{-2}$ & & 0.077 & 0.56 & $(1 \mathrm{~b})$ \\
\hline \multirow[t]{3}{*}{ [226] } & \multirow[t]{3}{*}{$\begin{array}{l}0.002-0.083 \mathrm{C}, 0.144-0.765 \mathrm{Mn}, 0.034-0.04 \mathrm{Al}, 0.003-0.083 \mathrm{Ti}, \\
0.001-0.024 \mathrm{Nb}\end{array}$} & $\mathrm{CMn}$ & $\mathrm{T}$ & 70 & 231 & $2.50 \times 10^{-2}$ & 0.20 & 0.210 & & (1a) \\
\hline & & HSLA & $\mathrm{T}$ & 45 & 394 & $1.04 \times 10^{-3}$ & 0.20 & 0.210 & & (1a) \\
\hline & & IF & $\mathrm{T}$ & 55 & 309 & $9.70 \times 10^{-3}$ & 0.20 & 0.210 & & (1a) \\
\hline \multirow[t]{2}{*}{ [227] } & \multirow[t]{2}{*}{$0.1-0.13 \mathrm{C}, 1.09-1.25 \mathrm{Mn}, 0.25-0.34 \mathrm{Si}, 0.032-0.047 \mathrm{Al},(0.018-0.047) \mathrm{Ti}$} & CSiMn & $\mathrm{T}$ & 290 & 279 & $1.02 \times 10^{-1}$ & 0.22 & 0.164 & 0.95 & (4a) \\
\hline & & $\mathrm{CMnSi}$ & $\mathrm{T}$ & 46 & 296 & $1.02 \times 10^{-1}$ & 0.22 & 0.116 & 0.95 & (4a) \\
\hline [63] & $0.19 \mathrm{C}, 0.4 \mathrm{Mn}, 0.2 \mathrm{Si}, 0.11 \mathrm{Cr}$ & CSiMn & $\mathrm{C}$ & & 194 & $3.85 \times 10^{-2}$ & & 0.115 & & $(1 \mathrm{~b})$ \\
\hline [228] & $0.0024 \mathrm{C}, 1.7 \mathrm{Mn}, 0.17 \mathrm{Si}, 0.021 \mathrm{Al}, 0.014 \mathrm{Ti}, 0.11 \mathrm{Nb}$ & TiNb IF & $\mathrm{T}$ & & 305 & $1.03 \times 10^{-2}$ & & 0.160 & 0.61 & $(1 \mathrm{~b})$ \\
\hline [229] & $0.12 \mathrm{C}, 0.85 \mathrm{Mn}, 0.08 \mathrm{Si}, 0.05 \mathrm{Cr}, 0.0015 \mathrm{~B}$ & Low $\mathrm{C}$ & C & $<170$ & & $5.50 \times 10^{-4}$ & 0.50 & 0.100 & 0.80 & (1a) \\
\hline \multirow[t]{6}{*}{ [198] } & \multirow{6}{*}{$\begin{array}{l}0.25-0.45 \mathrm{C}, 0.67-1.5 \mathrm{Mn}, 0.05-0.6 \mathrm{Si},(0.12-0.97) \mathrm{Cr},(0.15) \mathrm{Mo}, \\
(0.015-0.017) \mathrm{Ti},(0.1) \mathrm{V}\end{array}$} & VTi & $\mathrm{T}$ & & 296 & $3.80 \times 10^{-1}$ & & 0.157 & 0.62 & $(4 \mathrm{~b})$ \\
\hline & & $\mathrm{Ti}$ & $\mathrm{T}$ & & 258 & $3.51 \times 10^{-1}$ & & 0.186 & & $(4 \mathrm{~b})$ \\
\hline & & $\mathrm{CMn}$ & $\mathrm{T}$ & & 318 & $3.90 \times 10^{-1}$ & & 0.158 & 0.65 & $(4 b)$ \\
\hline & & VTi & $\mathrm{T}$ & & & $2.35 \times 10^{-1}$ & & 0.157 & & (4b) \\
\hline & & $\mathrm{Ti}$ & $\mathrm{T}$ & & & $2.94 \times 10^{-1}$ & & 0.166 & & $(4 \mathrm{~b})$ \\
\hline & & $\mathrm{CMn}$ & $\mathrm{T}$ & & & $2.52 \times 10^{-1}$ & & 0.158 & & (4b) \\
\hline \multirow[t]{3}{*}{ [230] } & \multirow{3}{*}{$\begin{array}{l}0.2-0.3 \mathrm{C}, 1.9-2 \mathrm{Mn}, 0.6-1.2 \mathrm{Si}, 0.0061-0.0279 \mathrm{Al}, 0.1-0.2 \mathrm{Ni} \text {, } \\
0.2-0.3 \mathrm{Mo}, 0.002-0.003 \mathrm{Ti}, 0.01 \mathrm{~V}\end{array}$} & B & C & 46 & 270 & $5.37 \times 10^{-2}$ & & 0.082 & & (1b) \\
\hline & & B & C & 63 & 270 & $2.24 \times 10^{-2}$ & & 0.122 & & (1b) \\
\hline & & B & C & 56 & 270 & $3.63 \times 10^{-2}$ & & 0.092 & & (1b) \\
\hline$[121,231]$ & $\begin{array}{l}0.002 \mathrm{C}, 0.13 \mathrm{Mn}, 0.02 \mathrm{Si}, 0.03 \mathrm{Al}, 0.037 \mathrm{Cr}, 0.025 \mathrm{Ni}, 0.008 \mathrm{Mo}, 0.062 \mathrm{Ti}, \\
0.002 \mathrm{Nb}, 0.002 \mathrm{~V}\end{array}$ & Ti IF & C & $<230$ & 344 & $4.00 \times 10^{-5}$ & 0.44 & 0.220 & 0.43 & (1a) \\
\hline \multirow[t]{5}{*}{ [134] } & \multirow{5}{*}{$0.0015-0.0028 \mathrm{C}, 1.1-21.1 \mathrm{Mn}, 0.005-0.018 \mathrm{Si}$} & FeMn & $\mathrm{T}$ & & 230 & $2.89 \times 10^{-2}$ & & 0.114 & & $(1 \mathrm{~b})$ \\
\hline & & FeMn & $\mathrm{T}$ & & 350 & $1.69 \times 10^{-2}$ & & 0.096 & & (1b) \\
\hline & & FeMn & $\mathrm{T}$ & & 317 & $1.70 \times 10^{-2}$ & & 0.108 & & (1b) \\
\hline & & FeMn & $\mathrm{T}$ & & 301 & $1.97 \times 10^{-2}$ & & 0.111 & & (1b) \\
\hline & & FeMn & $\mathrm{T}$ & & 279 & $1.62 \times 10^{-2}$ & & 0.129 & & (1b) \\
\hline \multirow[t]{2}{*}{ [232] } & \multirow{2}{*}{$\begin{array}{l}0.048-0.051 \mathrm{C}, 0.224-0.228 \mathrm{Mn}, 0.014-0.024 \mathrm{Si}, 0.05-0.071 \mathrm{Al}, \\
0.02-0.021 \mathrm{Cr}, 0.011-0.014 \mathrm{Ni}, 0.001-0.005 \mathrm{Mo}, 0.002 \mathrm{Ti},\end{array}$} & $\mathrm{B}$ & $\mathrm{C}$ & 50 & 388 & $4.10 \times 10^{-4}$ & 0.30 & 0.145 & 0.80 & (1a) \\
\hline & & B & C & 99 & 351 & $3.40 \times 10^{-4}$ & 0.30 & 0.170 & 0.80 & (1a) \\
\hline
\end{tabular}


Table A1. Cont.

\begin{tabular}{|c|c|c|c|c|c|c|c|c|c|c|}
\hline Ref. & Chemical Composition * & Steel & Test $^{\dagger}$ & $d_{0} \ddagger$ & $Q_{h w} \S$ & $\kappa-K$ & $n$ & $m-m^{\prime}$ & $R_{\varepsilon}$ & Eqn. \\
\hline [233] & $0.051 \mathrm{C}, 1.18 \mathrm{Mn}, 0.082 \mathrm{Si}, 0.042 \mathrm{Al}, 0.041 \mathrm{Nb}$ & $\mathrm{x} 52$ & $\mathrm{R}$ & & 241 & $1.90 \times 10^{-3}$ & 0.50 & 0.170 & 0.84 & (1a) \\
\hline [201] & $\begin{array}{l}0.131-0.151 \mathrm{C}, 0.996-1.51 \mathrm{Mn}, 0.286-0.46 \mathrm{Si},(0.241-0.258) \mathrm{Cr}, \\
(0.143-0.156) \mathrm{Mo}, 0.009-0.011 \mathrm{Ti}, 0.001-0.016 \mathrm{Nb}, 0.017-0.046 \mathrm{~V}\end{array}$ & $\mathrm{NbTiV}$ & $\mathrm{R}$ & 200 & 325 & $3.70 \times 10^{-3}$ & 0.15 & 0.155 & 0.77 & (6) \\
\hline \multirow[t]{2}{*}{ [60] } & \multirow{2}{*}{$0.03-0.5 \mathrm{C},(17) \mathrm{Mn}, 17-18.5 \mathrm{Cr},(8.9) \mathrm{Ni}$} & $\mathrm{CrNi}$ & $\mathrm{T}$ & & & $1.70 \times 10^{-2}$ & & 0.090 & & (1b) \\
\hline & & CrMn & $\mathrm{T}$ & & & $1.20 \times 10^{-2}$ & & 0.070 & & (1b) \\
\hline [234] & $0.02 \mathrm{C}, 0.28 \mathrm{Al}, 10.21 \mathrm{Cr}, 10.11 \mathrm{Ni}, 5.06 \mathrm{Mo}, 1.05 \mathrm{Ti}$ & $\mathrm{PH}$ & $\mathrm{C}$ & & 432 & $3.52 \times 10^{-4}$ & & 0.138 & 0.70 & (1b) \\
\hline [235] & $0.02 \mathrm{C}, 0.3 \mathrm{Si}, 10.21 \mathrm{Cr}, 10.11 \mathrm{Ni}, 5.06 \mathrm{Mo}, 1.05 \mathrm{Ti}, 1.03 \mathrm{~V}$ & V PH & $\mathrm{C}$ & & 460 & $4.30 \times 10^{-4}$ & & 0.140 & 0.70 & (1b) \\
\hline [236] & $0.02 \mathrm{C}, 0.3 \mathrm{Si}, 10.21 \mathrm{Cr}, 10.11 \mathrm{Ni}, 5.06 \mathrm{Mo}, 1.05 \mathrm{Ti}$ & $\mathrm{PH}$ & $\mathrm{C}$ & & 460 & $4.30 \times 10^{-4}$ & & 0.139 & & (1b) \\
\hline [55] & $\begin{array}{l}0.05-0.12 \mathrm{C}, 1.42-1.58 \mathrm{Mn}, 0.04-0.33 \mathrm{Si}, 0.023-0.039 \mathrm{Al},(0.15-0.31) \mathrm{Mo}, \\
0.001-0.007 \mathrm{Ti}, 0.028-0.035 \mathrm{Nb}\end{array}$ & $\mathrm{NbMo}$ & $\mathrm{T}$ & $<805$ & 325 & $3.70 \times 10^{-3}$ & 0.15 & 0.155 & 0.77 & (6) \\
\hline \multirow[t]{2}{*}{ [237] } & \multirow[t]{2}{*}{$0.157-0.233 \mathrm{C}, 1.47-1.54 \mathrm{Mn}, 0.45-1.365 \mathrm{Si}$} & SiMn & C & & 306 & $9.40 \times 10^{-2}$ & 0.20 & 0.160 & & (4a) \\
\hline & & $\mathrm{CMn}$ & $\mathrm{C}$ & & 269 & $9.40 \times 10^{-2}$ & 0.20 & 0.160 & & (4a) \\
\hline \multirow[t]{2}{*}{ [238] } & \multirow[t]{2}{*}{$0.094-0.1 \mathrm{C}, 0.5 \mathrm{Mn}, 0.15 \mathrm{Si}, 0.029-0.03 \mathrm{Al},(0.034) \mathrm{Nb}$} & $\mathrm{CMn}$ & $\mathrm{T}$ & & & & 0.15 & 0.150 & & (1a) \\
\hline & & $\mathrm{CMnNb}$ & $\mathrm{T}$ & & & & 0.15 & 0.150 & & (1a) \\
\hline [239] & $0.092 \mathrm{C}, 1.67 \mathrm{Mn}, 0.19 \mathrm{Si}, 30.3 \mathrm{Ni}, 1.51 \mathrm{Mo}$ & $\mathrm{Fe} 30 \mathrm{Ni}$ & $\mathrm{C}$ & 120 & 480 & $9.20 \times 10^{-6}$ & & 0.230 & 0.70 & $(1 b)$ \\
\hline [240] & $0.166 \mathrm{C}, 1.17 \mathrm{Mn}, 0.3 \mathrm{Si}$ & $\mathrm{CMn}$ & $\mathrm{C}$ & $\mathrm{R}$ & 300 & $5.60 \times 10^{-4}$ & 0.30 & 0.170 & & (1a) \\
\hline$[120]$ & Not reported & - & $\mathrm{T}$ & & & & & & 0.48 & \\
\hline$[241,242]$ & $0.043 \mathrm{C}, 1.635 \mathrm{Mn}, 0.285 \mathrm{Si}, 16.679 \mathrm{Cr}, 10.225 \mathrm{Ni}, 2.7 \mathrm{Mo}$ & AISI 316 & $\mathrm{C}$ & 46 & 398 & $4.90 \times 10^{-1}$ & & 0.127 & & (4b) \\
\hline [243] & Not reported & CMn & $\mathrm{R}$ & $<150$ & & $4.88 \times 10^{-4}$ & 0.90 & 0.170 & 1.00 & (1a) \\
\hline$[39,40]$ & $0.02 \mathrm{C}, 1.6 \mathrm{Mn}, 18.5 \mathrm{Cr}, 8.2 \mathrm{Ni}$ & AISI 304 & $\mathrm{~T}$ & 35 & 400 & & & 0.150 & 0.60 & (1b) \\
\hline [244] & $0.45 \mathrm{C}, 0.63 \mathrm{Mn}, 0.28 \mathrm{Si}, 0.96 \mathrm{Cr}, 0.19 \mathrm{Mo}$ & $42 \mathrm{CrMo}$ & $\mathrm{C}$ & & 463 & $2.92 \times 10^{-3}$ & & 0.102 & 0.80 & (1b) \\
\hline \multirow[t]{2}{*}[102]{} & \multirow[t]{2}{*}{$0.02 \mathrm{C}, 1.6 \mathrm{Mn}, 18.5 \mathrm{Cr}, 8.2 \mathrm{Ni}, 0.1 \mathrm{Mo}$} & \multirow[t]{2}{*}{ AISI 304} & $\mathrm{~T}$ & $<60$ & 400 & $2.65 \times 10^{-1}$ & & 0.055 & & (1b) \\
\hline & & & & & & $2.13 \times 10^{-1}$ & & 0.056 & & $(1 \mathrm{~b})$ \\
\hline$[64,245]$ & $0.45 \mathrm{C}, 0.63 \mathrm{Mn}, 0.28 \mathrm{Si}, 0.96 \mathrm{Cr}, 0.19 \mathrm{Mo}$ & 42CrMo & $\mathrm{C}$ & & & $3.80 \times 10^{-4}$ & 0.43 & 0.211 & 0.70 & (11a) \\
\hline [246] & $0.45 \mathrm{C}, 0.63 \mathrm{Mn}, 0.28 \mathrm{Si}, 0.96 \mathrm{Cr}, 0.19 \mathrm{Mo}$ & $42 \mathrm{CrMo}$ & $\mathrm{C}$ & & 321 & $1.76 \times 10^{-1}$ & & 0.008 & & (1b) \\
\hline [247] & $0.2 \mathrm{C}, 1.2 \mathrm{Mn}, 0.4 \mathrm{Si}, 0.02 \mathrm{Al},(0.03) \mathrm{Nb}$ & $20 \mathrm{MnSi}$ & $\mathrm{C}$ & 135 & 359 & & & & 0.52 & \\
\hline & & $20 \mathrm{MnSiNb}$ & $\mathrm{C}$ & 135 & 419 & & & & 0.52 & \\
\hline [248] & $0.13 \mathrm{C}, 0.17 \mathrm{Mn}, 0.01 \mathrm{Si}, 10.45 \mathrm{Cr}, 0.7 \mathrm{Ni}, 1.18 \mathrm{Mo}, 0.02 \mathrm{Nb}, 0.23 \mathrm{~V}, 0.004 \mathrm{~B}$ & $12 \mathrm{Cr}$ & $\mathrm{C}$ & & 439 & & & & 0.80 & \\
\hline [249] & $0.1 \mathrm{C}, 1.25 \mathrm{Mn}, 0.2 \mathrm{Si}, 0.002 \mathrm{Al}, 0.011 \mathrm{Ti}, 0.03 \mathrm{~V}$ & $\mathrm{Ti}$ & $\mathrm{T}$ & $<70$ & 312 & $5.77 \times 10^{-3}$ & 0.30 & 0.120 & & (1a) \\
\hline
\end{tabular}


Table A1. Cont.

\begin{tabular}{|c|c|c|c|c|c|c|c|c|c|c|}
\hline Ref. & Chemical Composition * & Steel & Test $^{+}$ & $d_{0} \ddagger$ & $Q_{h w} \S$ & $\kappa-K$ & $n$ & $m-m^{\prime}$ & $R_{\varepsilon}$ & Eqn. \\
\hline \multirow[t]{4}{*}{ [250] } & \multirow[t]{4}{*}{$\begin{array}{l}0.11-0.13 \mathrm{C}, 1.15-1.25 \mathrm{Mn}, 0.15-0.18 \mathrm{Si},(0.015-0.031) \mathrm{Ti}, \\
(0.038-0.039) \mathrm{Nb}\end{array}$} & Low C & $\mathrm{C}$ & & 335 & $2.50 \times 10^{-4}$ & 0.50 & 0.149 & 0.65 & (1a) \\
\hline & & Low $\mathrm{C}$ & $\mathrm{C}$ & & 423 & $3.50 \times 10^{-4}$ & 0.50 & 0.152 & 0.65 & (1a) \\
\hline & & Low $\mathrm{C}$ & $\mathrm{C}$ & & 361 & $2.60 \times 10^{-4}$ & 0.50 & 0.150 & 0.65 & (1a) \\
\hline & & Low C & $\mathrm{C}$ & & 436 & $2.90 \times 10^{-4}$ & 0.50 & 0.149 & 0.65 & (1a) \\
\hline [251] & $0.0135 \mathrm{C}, 1.48 \mathrm{Mn}, 0.33 \mathrm{Si}, 17.1 \mathrm{Cr}, 11.5 \mathrm{Ni}, 2.525 \mathrm{Mo}$ & AISI 316L & $\mathrm{C}$ & 270 & 460 & $4.73 \times 10^{-1}$ & 0.03 & 0.035 & 0.70 & (1a) \\
\hline [252] & $0.38 \mathrm{C}, 1.4 \mathrm{Mn}, 0.65 \mathrm{Si}, 0.16 \mathrm{Cr}, 0.04 \mathrm{Ni}, 0.02 \mathrm{Ti}, 0.1 \mathrm{~V}$ & V & $\mathrm{C}$ & 110 & 306 & $1.12 \times 10^{-2}$ & & 0.125 & 0.80 & (1b) \\
\hline \multirow[t]{3}{*}{ [253] } & \multirow{3}{*}{$\begin{array}{l}0.08-0.7 \mathrm{C}, 0.55-1.55 \mathrm{Mn}, 0.05-0.28 \mathrm{Si},(0.07) \mathrm{Al}, 0.07-0.23 \mathrm{Cr},(0.33) \mathrm{Ni}, \\
(0.028) \mathrm{Nb},(0.049) \mathrm{V},(0.0005-0.0015) \mathrm{B}\end{array}$} & Low $\mathrm{C}$ & $\mathrm{C}$ & & 338 & & & & 0.80 & \\
\hline & & High C & $\mathrm{C}$ & & 316 & & & & 0.80 & \\
\hline & & $\mathrm{NbV}$ & & & & & & & 0.80 & \\
\hline \multirow[t]{4}{*}{ [254] } & \multirow[t]{4}{*}{$\begin{array}{l}0.0038-0.042 \mathrm{C}, 1.464-1.469 \mathrm{Mn}, 0.297-0.354 \mathrm{Si}, 0.0021-0.0029 \mathrm{Al}, \\
0.0037-0.004 \mathrm{~V}, 0.0029-0.0105 \mathrm{~B}\end{array}$} & B & $\mathrm{C}$ & 86 & 270 & $7.97 \times 10^{-3}$ & & 0.160 & 1.00 & (1b) \\
\hline & & B & $\mathrm{C}$ & & 270 & $9.35 \times 10^{-3}$ & & 0.150 & 1.00 & (1b) \\
\hline & & B & $\mathrm{C}$ & & 270 & $1.41 \times 10^{-3}$ & & 0.130 & 1.00 & (1b) \\
\hline & & B & $\mathrm{C}$ & 80 & 270 & $1.61 \times 10^{-3}$ & & 0.120 & 1.00 & (1b) \\
\hline [255] & $0.18 \mathrm{C}, 1.11 \mathrm{Mn}, 0.71 \mathrm{Si}$ & 20SiMn & $\mathrm{C}$ & $<40$ & 318 & $5.00 \times 10^{-3}$ & 0.12 & 0.127 & 0.80 & (1a) \\
\hline [57] & $0.026 \mathrm{C}, 1.49 \mathrm{Mn}, 0.15 \mathrm{Si}, 0.097 \mathrm{Nb}$ & HTP & $\mathrm{R}$ & $<1200$ & & & 0.15 & 0.030 & & (7a) \\
\hline [65] & $0.99 \mathrm{C}, 0.31 \mathrm{Mn}, 0.24 \mathrm{Si}, 1.44 \mathrm{Cr}, 0.05 \mathrm{Ni}, 0.02 \mathrm{Mo}$ & GCr15 & $\mathrm{C}$ & & & $3.55 \times 10^{-3}$ & 0.22 & 0.190 & 0.83 & $(11 \mathrm{~b})$ \\
\hline [256] & $0.42 \mathrm{C}, 0.75 \mathrm{Mn}, 0.2 \mathrm{Si}, 1.05 \mathrm{Cr}$ & $41 \mathrm{Cr} 4$ & $\mathrm{C}$ & & 295 & $9.80 \times 10^{-3}$ & & 0.127 & & (1b) \\
\hline [257] & $0.06 \mathrm{C}, 1.1 \mathrm{Mn}, 0.15 \mathrm{Mo}, 0.035 \mathrm{Nb}$ & $\mathrm{Nb}$ & $\mathrm{R}$ & & 325 & $2.80 \times 10^{-3}$ & 0.15 & 0.155 & & (6) \\
\hline [258] & $0.1 \mathrm{C}$ & Low $\mathrm{C}$ & $\mathrm{R}$ & & 341 & $4.40 \times 10^{-4}$ & 0.50 & 0.089 & & (1a) \\
\hline [259] & $0.72-0.83 \mathrm{C}, 0.45-0.75 \mathrm{Mn}, 0.25 \mathrm{Si},(0.04) \mathrm{Al}, 0.1-0.3 \mathrm{Cr}$ & Eutectoid & M & $<124$ & 129 & $1.73 \times 10^{-2}$ & 0.18 & 0.145 & & (1a) \\
\hline [260] & $0.05 \mathrm{C}, 0.54 \mathrm{Mn}, 0.28 \mathrm{Si}$ & Low $\mathrm{C}$ & TE & 120 & 307 & $9.10 \times 10^{-4}$ & 0.48 & 0.130 & 0.65 & (1a) \\
\hline [261] & $0.18 \mathrm{C}, 1.87 \mathrm{Mn}, 0.48 \mathrm{Si}, 1.18 \mathrm{Al}, 0.03 \mathrm{Nb}$ & TRIP & $\mathrm{C}$ & $<106$ & 420 & $1.05 \times 10^{-3}$ & 0.11 & 0.145 & 0.79 & (1a) \\
\hline \multirow[t]{2}{*}{ [262] } & $0.032-0.035 \mathrm{C}, 0.367-0.372 \mathrm{Mn}, 0.239-0.26 \mathrm{Si}, 1.13-1.144 \mathrm{Cr}$, & AHSS & $\mathrm{C}$ & 31 & 270 & $6.48 \times 10^{-3}$ & & 0.180 & & (1b) \\
\hline & $1.91-1.93 \mathrm{Ni}, 0.007 \mathrm{Mo}, 0.193-0.195 \mathrm{~V}, 0.0003-0.0117 \mathrm{~B}$ & AHSS & $\mathrm{C}$ & 40 & & $1.71 \times 10^{-3}$ & & 0.230 & & (1b) \\
\hline [263] & $0.06 \mathrm{C}, 1 \mathrm{Mn}, 0.8 \mathrm{Si}, 13 \mathrm{Cr}$ & AISI 410 & $\mathrm{C}$ & & 448 & $1.85 \times 10^{-2}$ & & 0.072 & & (1b) \\
\hline$[123,264-267]$ & $0.03 \mathrm{C}, 0.6 \mathrm{Mn}, 0.54 \mathrm{Si}, 15.14 \mathrm{Cr}, 4.53 \mathrm{Ni}, 0.19 \mathrm{Mo}, 0.25 \mathrm{Nb}, 0.005 \mathrm{~V}$ & $17-4 \mathrm{PH}$ & $\mathrm{C}$ & & 337 & $1.80 \times 10^{-2}$ & & 0.110 & 0.47 & (1b) \\
\hline [66] & $0.45 \mathrm{C}, 0.63 \mathrm{Mn}, 0.28 \mathrm{Si}, 0.96 \mathrm{Cr}, 0.19 \mathrm{Mo}$ & $42 \mathrm{CrMo}$ & $\mathrm{C}$ & & 463 & $7.28 \times 10^{-4}$ & 0.31 & 0.211 & & (11a) \\
\hline
\end{tabular}


Table A1. Cont.

\begin{tabular}{|c|c|c|c|c|c|c|c|c|c|c|}
\hline Ref. & Chemical Composition * & Steel & Test $^{+}$ & $d_{0} \ddagger$ & $Q_{h w} \S$ & $\kappa-K$ & $n$ & $m-m^{\prime}$ & $R_{\varepsilon}$ & Eqn \\
\hline \multirow[t]{2}{*}{ [268-270] } & \multirow[t]{2}{*}{$0.06 \mathrm{C}, 1 \mathrm{Mn}, 0.8 \mathrm{Si}, 13 \mathrm{Cr}$} & \multirow[t]{2}{*}{ AISI 410} & \multirow[t]{2}{*}{$\mathrm{C}$} & & \multirow[t]{2}{*}{448} & $3.00 \times 10^{-3}$ & & 0.120 & 0.80 & (1b) \\
\hline & & & & & & $7.00 \times 10^{-3}$ & & 0.090 & & (1b) \\
\hline$[271,272]$ & $0.09 \mathrm{C}, 1.55 \mathrm{Mn}, 0.4 \mathrm{Si}, 0.028 \mathrm{Al}, 0.013 \mathrm{Ti}, 0.031 \mathrm{Nb}$ & $\mathrm{NbTi}$ & $\mathrm{T}$ & & 375 & $8.59 \times 10^{-4}$ & & 0.189 & 0.64 & (1b) \\
\hline [273] & $0.19 \mathrm{C}, 0.75 \mathrm{Mn}, 0.21 \mathrm{Si}$ & Low $\mathrm{C}$ & $\mathrm{C}$ & 124 & 140 & & & & 0.95 & \\
\hline [68] & Not reported & AISI 304 & C & & 373 & $6.00 \times 10^{-2}$ & & 0.070 & 0.46 & (1b) \\
\hline$[274]$ & $0.055 \mathrm{C}, 0.363 \mathrm{Mn}, 0.016 \mathrm{Si}, 0.033 \mathrm{Al}$ & SPHC & $\mathrm{C}$ & & 299 & $9.30 \times 10^{-4}$ & & 0.200 & & $(1 \mathrm{~b})$ \\
\hline [140] & $0.024-0.072 \mathrm{C}, 1.18-1.6 \mathrm{Mn}, 0.16-0.23 \mathrm{Si}, 0.027-0.058 \mathrm{Al}, 0.02-0.1 \mathrm{Nb}$ & $\mathrm{Nb}$ HSLA & $\mathrm{C}$ & $<65$ & 373 & & & 0.230 & & (1a) \\
\hline [56] & $0.11 \mathrm{C}, 1 \mathrm{Mn}, 0.11 \mathrm{Si}, 0.03 \mathrm{Al}, 0.034 \mathrm{Nb}$ & $\mathrm{Nb}$ & $\mathrm{T}$ & 365 & 402 & & 0.50 & 0.170 & & (6) \\
\hline [275] & $0.14 \mathrm{C}, 14.94 \mathrm{Mn}, 0.48 \mathrm{Si}, 22.58 \mathrm{Cr}, 0.42 \mathrm{Ni}$ & High $N$ & $\mathrm{C}$ & & 747 & & & & 0.56 & \\
\hline \multirow[t]{2}{*}{ [276] } & \multirow[t]{2}{*}{$0.05-0.06 \mathrm{C}, 1.75-1.85 \mathrm{Mn}, 0.18-0.2 \mathrm{Si}, 0.08-0.095 \mathrm{Mo}, 0.015 \mathrm{Ti}$} & X80 & C & & 365 & & & & 0.51 & \\
\hline & & $\mathrm{X} 100$ & $\mathrm{C}$ & & 395 & & & & 0.49 & \\
\hline [277] & $0.34 \mathrm{C}, 1.52 \mathrm{Mn}, 0.72 \mathrm{Si}, 0.0145 \mathrm{Al}, 0.018 \mathrm{Ti}, 0.083 \mathrm{~V}$ & Med. CV & $\mathrm{C}$ & & 394 & $7.90 \times 10^{-3}$ & & 0.103 & 0.62 & $(1 b)$ \\
\hline [278] & $0.04 \mathrm{C}, 0.72 \mathrm{Si}, 16.1 \mathrm{Cr}, 25.5 \mathrm{Ni}, 5.8 \mathrm{Mo}$ & $16 \mathrm{Cr} 25 \mathrm{Ni}$ & $\mathrm{C}$ & & 484 & & & & 0.60 & \\
\hline [279] & $0.45 \mathrm{C}, 0.63 \mathrm{Mn}, 0.28 \mathrm{Si}, 0.96 \mathrm{Cr}, 0.19 \mathrm{Mo}$ & 42CrMo & $\mathrm{C}$ & $>85$ & 600 & $1.67 \times 10^{-1}$ & & 0.067 & 0.37 & $(4 \mathrm{~b})$ \\
\hline [280] & $\begin{array}{l}0.04 \mathrm{C}, 0.78 \mathrm{Mn}, 0.25 \mathrm{Si}, 0.62 \mathrm{Cr}, 3.55 \mathrm{Ni}, 0.64 \mathrm{Mo}, 0.009 \mathrm{Ti}, 0.033 \mathrm{Nb}, \\
0.015 \mathrm{~V}\end{array}$ & HSLA100 & $\mathrm{C}$ & & 377 & $1.40 \times 10^{-2}$ & & 0.110 & & $(1 b)$ \\
\hline [281] & $0.16 \mathrm{C}, 0.46 \mathrm{Mn}, 0.28 \mathrm{Si}, 11.98 \mathrm{Cr}, 0.12 \mathrm{Ni}, 0.029 \mathrm{Mo}, 0.22 \mathrm{Nb}, 0.0128 \mathrm{~V}$ & $403 \mathrm{Nb}$ & $\mathrm{C}$ & & 367 & $1.90 \times 10^{-3}$ & & 0.161 & 0.66 & $(1 b)$ \\
\hline [282] & $0.03 \mathrm{C}, 25.45 \mathrm{Mn}, 3.06 \mathrm{Si}, 2.88 \mathrm{Al}$ & TWIP & $\mathrm{C}$ & 150 & 406 & $8.65 \times 10^{-3}$ & & 0.087 & 0.70 & $(1 b)$ \\
\hline [283] & $\begin{array}{l}0.084 \mathrm{C}, 1.049 \mathrm{Mn}, 0.199 \mathrm{Si}, 0.038 \mathrm{Al}, 0.019 \mathrm{Cr}, 0.017 \mathrm{Ni}, 0.007 \mathrm{Mo}, \\
0.003 \mathrm{Ti}, 0.026 \mathrm{Nb}, 0.003 \mathrm{~V}\end{array}$ & $\mathrm{Nb}$ & $\mathrm{C}$ & 60 & 379 & $1.02 \times 10^{-4}$ & 0.50 & 0.184 & & (1a) \\
\hline [284] & $0.57 \mathrm{C}, 23.2 \mathrm{Mn}, 0.17 \mathrm{Si}, 0.01 \mathrm{Al}, 0.31 \mathrm{Cr}, 0.19 \mathrm{Ni}, 0.04 \mathrm{Mo}$ & Fe26Mn06C & $\mathrm{C}$ & 90 & 439 & $4.79 \times 10^{-3}$ & & 0.112 & 0.55 & (1b) \\
\hline [285] & $\begin{array}{l}0.0038-0.042 \mathrm{C}, 1.464-1.469 \mathrm{Mn}, 0.297-0.354 \mathrm{Si}, 0.0021-0.0029 \mathrm{Al}, \\
0.0037-0.004 \mathrm{~V}, 0.0029-0.0105 \mathrm{~B}\end{array}$ & B & $\mathrm{C}$ & 83 & & & & & 0.53 & \\
\hline [286] & $0.33 \mathrm{C}, 0.67 \mathrm{Mn}, 0.32 \mathrm{Si}, 1 \mathrm{Cr}, 0.21 \mathrm{Mo}$ & AISI 4130 & $\mathrm{C}$ & & 491 & $9.80 \times 10^{-3}$ & & 0.080 & 0.80 & $(1 b)$ \\
\hline [287] & $0.18 \mathrm{C}, 1.42 \mathrm{Mn}, 0.18 \mathrm{Si}, 0.13 \mathrm{Cr}, 0.89 \mathrm{Ni}, 0.5 \mathrm{Mo}$ & SA508-3 & $\mathrm{C}$ & 20 & 333 & $3.63 \times 10^{-3}$ & 0.46 & 0.092 & 0.85 & (1a) \\
\hline \multirow[t]{2}{*}{ [288] } & \multirow[t]{2}{*}{$0.12 \mathrm{C}, 1.55 \mathrm{Mn}, 0.25 \mathrm{Si}, 0.033 \mathrm{~V}$} & \multirow[t]{2}{*}{$\mathrm{MnCuV}$} & $\mathrm{C}$ & & 551 & $2.19 \times 10^{-4}$ & & 0.141 & & (1b) \\
\hline & & & & & & $1.35 \times 10^{-4}$ & & 0.145 & & $(1 \mathrm{~b})$ \\
\hline [289] & $\begin{array}{l}0.097 \mathrm{C}, 0.5 \mathrm{Mn}, 0.34 \mathrm{Si}, 8.87 \mathrm{Cr}, 0.27 \mathrm{Ni}, 0.48 \mathrm{Mo}, 0.076 \mathrm{Nb}, 0.2 \mathrm{~V}, \\
0.0032 \mathrm{~B}\end{array}$ & P92 & $\mathrm{C}$ & & 437 & & & & 0.80 & \\
\hline
\end{tabular}


Table A1. Cont.

\begin{tabular}{|c|c|c|c|c|c|c|c|c|c|c|}
\hline Ref. & Chemical Composition * & Steel & Test $^{+}$ & $d_{0} \ddagger$ & $Q_{h w} \S$ & $\kappa-K$ & $n$ & $m-m^{\prime}$ & $R_{\varepsilon}$ & Eqn. \\
\hline [290] & $0.16 \mathrm{C}, 1.53 \mathrm{Mn}, 0.52 \mathrm{Si}, 0.027 \mathrm{Nb}$ & $\mathrm{Nb}$ & $\mathrm{C}$ & & 360 & & & & 0.80 & \\
\hline [291] & $0.45 \mathrm{C}, 0.63 \mathrm{Mn}, 0.28 \mathrm{Si}, 0.96 \mathrm{Cr}, 0.19 \mathrm{Mo}$ & $42 \mathrm{CrMo}$ & $\mathrm{C}$ & $<155$ & 247 & $7.28 \times 10^{-4}$ & 0.31 & 0.210 & 0.70 & (1a) \\
\hline [292] & $0.05 \mathrm{C}, 1.56 \mathrm{Mn}, 0.23 \mathrm{Si}, 0.033 \mathrm{Al}, 0.02 \mathrm{Ni}, 0.17 \mathrm{Mo}, 0.015 \mathrm{Ti}, 0.046 \mathrm{Nb}$ & X70 & $\mathrm{C}$ & & 393 & $2.60 \times 10^{-4}$ & & 0.216 & 0.40 & (1b) \\
\hline [293] & $0.27 \mathrm{C}, 0.3 \mathrm{Mn}, 0.2 \mathrm{Si}, 1.5 \mathrm{Cr}, 3.7 \mathrm{Ni}, 0.35 \mathrm{Mo}, 0.1 \mathrm{~V}$ & 26NiCrMoV14-5 & $5 \mathrm{C}$ & & 437 & $1.10 \times 10^{-3}$ & & 0.159 & 0.70 & (1b) \\
\hline [294] & $0.17 \mathrm{C}, 0.68 \mathrm{Mn}, 0.22 \mathrm{Si}$ & Q235A & $\mathrm{C}$ & $<450$ & 495 & $2.28 \times 10^{-5}$ & & 0.198 & & (1b) \\
\hline \multirow[t]{2}{*}{ [295] } & \multirow[t]{2}{*}{$0.05 \mathrm{C}, 1 \mathrm{Mn}, 0.8 \mathrm{Si}, 13.09 \mathrm{Cr}$} & \multirow[t]{2}{*}{$13 \mathrm{Cr}$} & $\mathrm{C}$ & 176 & 413 & $6.00 \times 10^{-4}$ & & 0.430 & 0.68 & (1b) \\
\hline & & & & & & $2.80 \times 10^{-4}$ & & 0.450 & & (1b) \\
\hline$[231,296]$ & $\begin{array}{l}0.002 \mathrm{C}, 0.13 \mathrm{Mn}, 0.02 \mathrm{Si}, 0.03 \mathrm{Al}, 0.037 \mathrm{Cr}, 0.025 \mathrm{Ni}, 0.008 \mathrm{Mo}, 0.062 \mathrm{Ti}, \\
0.002 \mathrm{Nb}, 0.002 \mathrm{~V}\end{array}$ & Ti IF & $\mathrm{T}$ & & & & & & 0.43 & \\
\hline \multirow[t]{2}{*}[297,298]{} & \multirow[t]{2}{*}{$0.42 \mathrm{C}, 1.33 \mathrm{Mn}, 0.76 \mathrm{Si}, 0.13 \mathrm{Cr}, 0.017 \mathrm{Ni}, 0.02 \mathrm{Ti}, 0.1 \mathrm{~V}$} & \multirow[t]{2}{*}{$38 \mathrm{MnVS}$} & $\mathrm{C}$ & & 275 & $4.27 \times 10^{-2}$ & & 0.130 & 0.80 & (1b) \\
\hline & & & & & & $4.67 \times 10^{-3}$ & & 0.110 & & (1b) \\
\hline \multirow[t]{3}{*}{ [299] } & \multirow[t]{3}{*}{$0.45 \mathrm{C}, 1.22 \mathrm{Mn}, 0.25 \mathrm{Si}, 0.032 \mathrm{Al}, 0.15 \mathrm{Cr}, 0.12 \mathrm{~V}$} & \multirow{3}{*}{$\begin{array}{c}\text { AlVN air } \\
\text { cool. } \\
\text { AlVN water } \\
\text { cool. } \\
\text { AlVN water } \\
\text { cool. }\end{array}$} & $\mathrm{C}$ & 130 & 420 & $6.90 \times 10^{-3}$ & & 0.100 & 0.65 & (1b) \\
\hline & & & $\mathrm{C}$ & 130 & 480 & $5.60 \times 10^{-3}$ & & 0.090 & & (1b) \\
\hline & & & C & & & $3.90 \times 10^{-3}$ & & 0.080 & & (1b) \\
\hline \multirow[t]{2}{*}{ [300] } & \multirow[t]{2}{*}{$0.56 \mathrm{C}, 15.83 \mathrm{Mn}$} & \multirow[t]{2}{*}{ CuFe16Mn06C } & $\mathrm{C}$ & & 505 & $9.08 \times 10^{-2}$ & & 0.019 & & (1b) \\
\hline & & & & & & $3.32 \times 10^{-2}$ & & 0.028 & & (1b) \\
\hline [301] & $\begin{array}{l}0.105 \mathrm{C}, 0.7 \mathrm{Mn}, 0.5 \mathrm{Si}, 11.25 \mathrm{Cr}, 0.5 \mathrm{Ni}, 0.425 \mathrm{Mo}, 0.07 \mathrm{Nb}, 0.225 \mathrm{~V}, \\
0.005 \mathrm{~B}\end{array}$ & T122 & $\mathrm{C}$ & 440 & & $1.63 \times 10^{-6}$ & & 0.421 & & (5) \\
\hline \multirow[t]{2}{*}[75]{} & \multirow[t]{2}{*}{$0.1 \mathrm{C}, 1 \mathrm{Mn}, 0.17 \mathrm{Si}, 0.02 \mathrm{Al}, 12 \mathrm{Cr}, 1 \mathrm{Ni}, 1 \mathrm{Mo}, 0.2 \mathrm{~V}, 0.001 \mathrm{~B}$} & \multirow[t]{2}{*}{ CNS-II F/M } & $\mathrm{C}$ & & 465 & $6.58 \times 10^{12}$ & & 0.551 & 0.50 & (1b) \\
\hline & & & & & & $3.29 \times 10^{15}$ & & 0.678 & & (1b) \\
\hline [302] & $0.009 \mathrm{C}, 1.5 \mathrm{Mn}, 0.42 \mathrm{Si}, 20.1 \mathrm{Cr}, 25.59 \mathrm{Ni}, 4.49 \mathrm{Mo}$ & AISI 904L & $\mathrm{C}$ & $>200$ & 459 & $5.24 \times 10^{-6}$ & & 0.250 & & (1b) \\
\hline \multirow[t]{2}{*}[303,304]{} & \multirow{2}{*}{$\begin{array}{l}0.23-0.26 \mathrm{C}, 1.5-1.56 \mathrm{Mn}, 0.1-1.72 \mathrm{Si}, 0.1-1.79 \mathrm{Al}, 1-1.07 \mathrm{Cr}, 1-1.03 \mathrm{Ni}, \\
0.25-0.26 \mathrm{Mo}, 0.025 \mathrm{Ti}, 0.06 \mathrm{Nb}, 0.0051-0.006 \mathrm{~B}\end{array}$} & High Si & $\mathrm{C}$ & & 396 & $1.97 \times 10^{-3}$ & & 0.149 & & (1b) \\
\hline & & High Al & $\mathrm{C}$ & & 310 & $3.13 \times 10^{-2}$ & & 0.100 & & (1b) \\
\hline [305] & $0.39 \mathrm{C}, 0.69 \mathrm{Mn}, 1.61 \mathrm{Si}, 0.91 \mathrm{Cr}, 1.82 \mathrm{Ni}, 0.42 \mathrm{Mo}, 0.07 \mathrm{~V}$ & $300 \mathrm{M}$ & $\mathrm{C}$ & $<150$ & 381 & $2.20 \times 10^{-1}$ & -0.25 & 0.030 & 0.80 & (1a) \\
\hline [306] & $0.02 \mathrm{C}, 1.76 \mathrm{Mn}, 18.38 \mathrm{Cr}, 8.37 \mathrm{Ni}, 0.4 \mathrm{Mo}$ & AISI 304L & $\mathrm{C}$ & $<140$ & 392 & & & & 0.53 & \\
\hline [307] & $0.55 \mathrm{C}, 0.75 \mathrm{Mn}, 1.3 \mathrm{Si}, 0.49 \mathrm{Mo}$ & 55SiMnMo & $\mathrm{C}$ & & & $4.36 \times 10^{-4}$ & 0.30 & 0.113 & 0.83 & (11a) \\
\hline \multirow[t]{2}{*}{ [308] } & \multirow[t]{2}{*}{$0.36 \mathrm{C}, 1.42 \mathrm{Mn}, 0.27 \mathrm{Si}, 0.001 \mathrm{Al}, 0.089 \mathrm{~V}$} & \multirow{2}{*}{ Med. CV } & $\mathrm{C}$ & & 273 & $5.64 \times 10^{-3}$ & & 0.175 & 0.42 & (1b) \\
\hline & & & & & & $2.81 \times 10^{-4}$ & & 0.262 & & (1b) \\
\hline
\end{tabular}


Table A1. Cont.

\begin{tabular}{|c|c|c|c|c|c|c|c|c|c|c|}
\hline Ref. & Chemical Composition * & Steel & Test $^{\dagger}$ & $d_{0} \ddagger$ & $Q_{h w} \S$ & $\kappa-K$ & $n$ & $m-m^{\prime}$ & $R_{\varepsilon}$ & Eqn. \\
\hline [309] & $0.02 \mathrm{C}, 0.82 \mathrm{Mn}, 0.87 \mathrm{Si}, 21.23 \mathrm{Cr}, 6.55 \mathrm{Ni}, 3.03 \mathrm{Mo}$ & 1.4462 DSS & $\mathrm{C}$ & & 526 & $4.05 \times 10^{-3}$ & & 0.110 & & (1b) \\
\hline [310] & $0.32 \mathrm{C}, 1.26 \mathrm{Mn}, 0.29 \mathrm{Si}, 1.9 \mathrm{Cr}, 0.97 \mathrm{Ni}, 0.39 \mathrm{Mo}$ & 3Cr2NiMnMo & $\mathrm{C}$ & 97 & 346 & & & & 0.80 & \\
\hline [311] & $\begin{array}{l}0.07-0.09 \mathrm{C}, 1.2-1.51 \mathrm{Mn}, 0.04 \mathrm{Al}, 0.02-0.1 \mathrm{Cr}, 0.02-0.12 \mathrm{Ni}, 0-0.27 \mathrm{Mo} \text {, } \\
0.016-0.035 \mathrm{Ti}, 0.045-0.067 \mathrm{Nb}, 0.003 \mathrm{~V}, 0.0003 \mathrm{~B}\end{array}$ & $\begin{array}{c}\text { Low } \\
\text { CMoNbTi }\end{array}$ & $\mathrm{C}$ & & & & & & 0.42 & \\
\hline [312] & $\begin{array}{l}0.072 \mathrm{C}, 1.45 \mathrm{Mn}, 0.201 \mathrm{Si}, 0.023 \mathrm{Al}, 0.174 \mathrm{Cr}, 0.009 \mathrm{Ni}, 0.24 \mathrm{Mo}, 0.015 \mathrm{Ti}, \\
0.047 \mathrm{Nb}, 0.05 \mathrm{~V}\end{array}$ & X65 & $\mathrm{C}$ & & 330 & $4.48 \times 10^{-3}$ & & 0.153 & 0.60 & (1b) \\
\hline \multirow[t]{2}{*}{ [313] } & \multirow{2}{*}{$\begin{array}{l}0.052-0.059 \mathrm{C}, 0.78-0.79 \mathrm{Mn}, 0.17 \mathrm{Si}, 0.22-0.24 \mathrm{Cr}, 4.99-5.19 \mathrm{Ni}, \\
0.19-0.2 \mathrm{Mo}, 0.005-0.04 \mathrm{Nb}\end{array}$} & A340 & $\mathrm{C}$ & & 394 & & & & 0.83 & \\
\hline & & B270 & $\mathrm{C}$ & & 462 & & & & 0.83 & \\
\hline [314] & $0.03 \mathrm{C}, 0.5 \mathrm{Mn}, 0.3 \mathrm{Si}, 29 \mathrm{Ni}$ & Fe29Ni17Co & $\mathrm{C}$ & & 423 & $1.70 \times 10^{-3}$ & & 0.160 & & (1b) \\
\hline [315] & $\begin{array}{l}0.076 \mathrm{C}, 0.45 \mathrm{Mn}, 0.18 \mathrm{Si}, 0.025 \mathrm{Al}, 8.83 \mathrm{Cr}, 0.043 \mathrm{Ni}, 0.005 \mathrm{Ti}, 0.042 \mathrm{Nb}, \\
0.19 \mathrm{~V}, 0.013 \mathrm{~B}\end{array}$ & G115 & $\mathrm{C}$ & & 494 & & & & 0.80 & \\
\hline [316] & $0.55 \mathrm{C}, 0.75 \mathrm{Mn}, 1.3 \mathrm{Si}, 0.49 \mathrm{Mo}$ & 55SiMnMo & $\mathrm{C}$ & & 319 & $2.67 \times 10^{-3}$ & & 0.132 & 0.45 & (1b) \\
\hline [317] & $0.082 \mathrm{C}, 1.47 \mathrm{Mn}, 0.36 \mathrm{Si}, 0.053 \mathrm{Al}, 0.03 \mathrm{Ni}, 0.051 \mathrm{Nb}, 0.08 \mathrm{~V}$ & $\mathrm{Nb}$ & $\mathrm{C}$ & 208 & & $3.70 \times 10^{-3}$ & 0.15 & 0.155 & & (6) \\
\hline [318] & $0.018 \mathrm{C}, 1.2 \mathrm{Mn}, 0.27 \mathrm{Si}, 0.04 \mathrm{Al}, 0.1 \mathrm{Mo}, 0.021 \mathrm{Ti}, 0.06 \mathrm{Nb}, 0.003 \mathrm{~V}$ & X70 & $\mathrm{C}$ & 19 & 418 & $2.80 \times 10^{-3}$ & & 0.129 & & (1b) \\
\hline \multirow[t]{2}{*}{ [319] } & \multirow[t]{2}{*}{$0.08 \mathrm{C}, 1.06 \mathrm{Mn}, 0.2 \mathrm{Si}, 0.5 \mathrm{Cr}, 0.28 \mathrm{Ni}, 0.18 \mathrm{Mo}, 0.01 \mathrm{Ti}, 0.04 \mathrm{Nb}$} & \multirow[t]{2}{*}{ Low $\mathrm{C}$} & $C$ & $<75$ & 442 & $4.68 \times 10^{-3}$ & & 0.109 & 0.53 & (1b) \\
\hline & & & & & & $1.52 \times 10^{-2}$ & & 0.059 & & (1b) \\
\hline [320] & \multirow{9}{*}{$\begin{array}{l}0.99 \mathrm{C}, 0.31 \mathrm{Mn}, 0.23 \mathrm{Si}, 0.022 \mathrm{Al}, 1.47 \mathrm{Cr}, 0.04 \mathrm{Ni}, 0.02 \mathrm{Mo} \\
0.15-0.47 \mathrm{C}, 0.63-1.73 \mathrm{Mn}, 0.24-0.47 \mathrm{Si}, 0.007-0.012 \mathrm{Al}, 0.075-0.22 \mathrm{Cr} \\
0.01-0.034 \mathrm{Mo}\end{array}$} & GCr15 & C & & 356 & $1.00 \times 10^{-2}$ & & 0.440 & 0.80 & (11) \\
\hline \multirow[t]{8}{*}{ [135] } & & $\mathrm{CMnSi}$ & C & 104 & 270 & $6.90 \times 10^{-3}$ & & 0.163 & 0.53 & (1b) \\
\hline & & $\mathrm{CMnSi}$ & C & 70 & 270 & $6.44 \times 10^{-3}$ & & 0.168 & 0.53 & (1b) \\
\hline & & $\mathrm{CMnSi}$ & $\mathrm{C}$ & 90 & 270 & $7.82 \times 10^{-3}$ & & 0.160 & 0.53 & (1b) \\
\hline & & $\mathrm{CMnSi}$ & $\mathrm{C}$ & 65 & 270 & $6.75 \times 10^{-3}$ & & 0.166 & 0.53 & (1b) \\
\hline & & $\mathrm{CMnSi}$ & C & 101 & 270 & $7.99 \times 10^{-3}$ & & 0.146 & 0.53 & (1b) \\
\hline & & $\mathrm{CMnSi}$ & $\mathrm{C}$ & 82 & 270 & $7.63 \times 10^{-3}$ & & 0.152 & 0.53 & (1b) \\
\hline & & $\mathrm{CMnSi}$ & $\mathrm{C}$ & 100 & 270 & $8.30 \times 10^{-3}$ & & 0.148 & 0.53 & (1b) \\
\hline & & $\mathrm{CMnSi}$ & $\mathrm{C}$ & 103 & 270 & $8.38 \times 10^{-3}$ & & 0.149 & 0.53 & (1b) \\
\hline [321] & $0.43 \mathrm{C}, 1.451 \mathrm{Mn}, 0.623 \mathrm{Si}, 0.017 \mathrm{Al}, 0.198 \mathrm{Cr}, 0.017 \mathrm{Ti}, 0.113 \mathrm{~V}$ & 38MnVS6 & $\mathrm{C}$ & & 348 & $5.80 \times 10^{-3}$ & & 0.123 & 0.77 & (1b) \\
\hline [322] & $0.021 \mathrm{C}, 1.25 \mathrm{Mn}, 0.09 \mathrm{Si}, 9.37 \mathrm{Cr}, 0.06 \mathrm{Nb}, 0.15 \mathrm{~V}$ & NS & $\mathrm{C}$ & & 451 & & & & 0.45 & \\
\hline
\end{tabular}


Table A1. Cont.

\begin{tabular}{|c|c|c|c|c|c|c|c|c|c|c|}
\hline Ref. & Chemical Composition * & Steel & Test $^{\dagger}$ & $d_{0} \ddagger$ & $Q_{h w} \S$ & $\kappa-K$ & $n$ & $m-m^{\prime}$ & $\boldsymbol{R}_{\varepsilon}$ & Eqn. \\
\hline [67] & $0.96 \mathrm{C}, 0.36 \mathrm{Mn}, 0.19 \mathrm{Si}, 1.46 \mathrm{Cr}, 0.08 \mathrm{Ni}, 0.02 \mathrm{Mo}$ & GCr15 & $\mathrm{C}$ & $<203$ & & $3.38 \times 10^{-2}$ & 0.03 & 0.197 & 0.78 & (11a) \\
\hline \multirow[t]{2}{*}{ [323] } & \multirow[t]{2}{*}{$0.19 \mathrm{C}, 1.5 \mathrm{Mn}, 0.37 \mathrm{Si}, 0.019 \mathrm{Ti}, 0.06 \mathrm{~V}$} & \multirow[t]{2}{*}{ Low CVN } & $\mathrm{C}$ & & 309 & $1.05 \times 10^{-2}$ & & 0.112 & 0.48 & (1b) \\
\hline & & & & & & $9.18 \times 10^{-3}$ & & 0.095 & & (1b) \\
\hline \multirow[t]{2}{*}{ [324] } & \multirow{2}{*}{$\begin{array}{l}0.024-0.027 \mathrm{C}, 1.08-1.43 \mathrm{Mn}, 0.38-0.59 \mathrm{Si}, 0.003-0.012 \mathrm{Al}, \\
17.13-18.21 \mathrm{Cr}, 8.11-9.11 \mathrm{Ni}, 0.001-0.346 \mathrm{Ti}, 0.0003-0.0031 \mathrm{~B}\end{array}$} & AISI 304 & $\mathrm{C}$ & & 446 & $1.80 \times 10^{-3}$ & & 0.130 & 0.68 & (1b) \\
\hline & & AISI 321 & $\mathrm{C}$ & & 465 & $1.90 \times 10^{-3}$ & & 0.130 & 0.69 & (1b) \\
\hline \multirow[t]{4}{*}{ [325] } & \multirow[t]{4}{*}{$0.0055-0.37 \mathrm{C}, 1.45-1.46 \mathrm{Mn}, 0.38 \mathrm{Si}, 0.001 \mathrm{Al}, 0.08-0.089 \mathrm{~V}$} & V & $\mathrm{C}$ & & 288 & $7.75 \times 10^{-3}$ & & 0.156 & 0.39 & (1b) \\
\hline & & $\mathrm{V}$ & $\mathrm{C}$ & & 280 & $1.92 \times 10^{-3}$ & & 0.174 & 0.38 & (1b) \\
\hline & & $\mathrm{V}$ & $\mathrm{C}$ & & & $5.65 \times 10^{-3}$ & & 0.170 & & (1b) \\
\hline & & $\mathrm{V}$ & $\mathrm{C}$ & & & $1.57 \times 10^{-3}$ & & 0.182 & & (1b) \\
\hline [124] & Not reported & AISI 304 & $\mathrm{C}$ & & & & & & 0.68 & \\
\hline \multirow[t]{6}{*}{ [326] } & \multirow[t]{6}{*}{$\begin{array}{l}(0.055-0.36) \mathrm{C},(1.41-1.42) \mathrm{Mn},(0.27-0.35) \mathrm{Si},(0.001) \mathrm{Al}, \\
(0.036-0.044) \mathrm{Nb}\end{array}$} & $\mathrm{CMn}$ & $\mathrm{C}$ & & 278 & $1.16 \times 10^{-2}$ & & 0.140 & 0.39 & (1b) \\
\hline & & $\mathrm{Nb}$ & C & & 347 & $2.63 \times 10^{-2}$ & & 0.009 & 0.45 & (1b) \\
\hline & & $\mathrm{Nb}$ & C & & 360 & $1.57 \times 10^{-3}$ & & 0.183 & 0.34 & (1b) \\
\hline & & $\mathrm{CMn}$ & C & & & $3.27 \times 10^{-3}$ & & 0.153 & & (1b) \\
\hline & & $\mathrm{Nb}$ & $\mathrm{C}$ & & & $2.86 \times 10^{-3}$ & & 0.141 & & (1b) \\
\hline & & $\mathrm{Nb}$ & $\mathrm{C}$ & & & $1.17 \times 10^{-3}$ & & 0.157 & & (1b) \\
\hline [327] & $0.025 \mathrm{C}, 1.74 \mathrm{Mn}, 0.2 \mathrm{Si}, 17.57 \mathrm{Cr}, 12.15 \mathrm{Ni}, 2.53 \mathrm{Mo}$ & AISI 316L & $\mathrm{C}$ & & 433 & $2.36 \times 10^{-1}$ & & 0.022 & & (1b) \\
\hline [328] & $0.1 \mathrm{C}, 1.35 \mathrm{Mn}, 0.03 \mathrm{Si}, 0.01 \mathrm{Al}$ & Low CS & $\mathrm{C}$ & & 330 & $1.00 \times 10^{-2}$ & & 0.110 & 0.50 & (1b) \\
\hline [329] & $0.04 \mathrm{C}, 1.61 \mathrm{Mn}, 0.17 \mathrm{Si}, 0.014 \mathrm{Ti}, 0.06 \mathrm{Nb}, 0.03 \mathrm{~V}$ & $\mathrm{NbTiV}$ & C & 804 & 332 & $2.27 \times 10^{-3}$ & 0.15 & 0.160 & 0.68 & (1a) \\
\hline [330] & $0.06 \mathrm{C}, 1.5 \mathrm{Mn}, 0.6 \mathrm{Si}, 0.03 \mathrm{Al}, 0.03 \mathrm{Ti}, 0.03 \mathrm{Nb}, 0.01 \mathrm{~V}$ & $\mathrm{CMnVNb}$ & C & $<135$ & 210 & $1.60 \times 10^{-1}$ & 0.42 & 0.160 & 0.80 & (1a) \\
\hline \multirow[t]{2}{*}{ [331] } & \multirow[t]{2}{*}{$0.11 \mathrm{C}, 21 \mathrm{Mn}, 2.7 \mathrm{Si}, 1.6 \mathrm{Al}$} & \multirow[t]{2}{*}{ TWIP } & C & & & $4.74 \times 10^{-2}$ & & 0.052 & 0.43 & (1b) \\
\hline & & & & & & & & 0.009 & & $(7 \mathrm{~b})$ \\
\hline \multirow[t]{2}{*}{ [332] } & \multirow[t]{2}{*}{$0.241 \mathrm{C}, 1.538 \mathrm{Mn}, 0.287 \mathrm{Si}, 0.026 \mathrm{Al}, 0.197 \mathrm{Cr}, 0.002 \mathrm{Ti}, 0.049 \mathrm{Nb}, 0.12 \mathrm{~V}$} & \multirow[t]{2}{*}{ Med. CNbV } & $\mathrm{C}$ & & 458 & $1.72 \times 10^{-3}$ & & 0.132 & 0.37 & (1b) \\
\hline & & & & & & $3.04 \times 10^{-3}$ & & 0.090 & & (1b) \\
\hline \multirow[t]{2}{*}{ [333] } & \multirow[t]{2}{*}{$0.45 \mathrm{C}, 1.2 \mathrm{Mn}, 0.15 \mathrm{Si}, 0.02 \mathrm{Al}, 0.1 \mathrm{Cr}, 0.2 \mathrm{Ni}, 0.05 \mathrm{Mo}, 0.08 \mathrm{~V}$} & \multirow[t]{2}{*}{ S45CVMn } & $\mathrm{C}$ & 140 & 379 & $8.15 \times 10^{-3}$ & & 0.107 & 0.68 & (1b) \\
\hline & & & & & & $5.46 \times 10^{-3}$ & & 0.112 & & (1b) \\
\hline [334] & $0.36 \mathrm{C}, 0.65 \mathrm{Mn}, 0.22 \mathrm{Si}, 0.95 \mathrm{Cr}, 0.2 \mathrm{Mo}$ & 35CrMo & $\mathrm{C}$ & 100 & 305 & $6.98 \times 10^{-4}$ & 0.30 & 0.168 & 0.80 & (1a) \\
\hline [335] & $0.28 \mathrm{C}, 0.22 \mathrm{Mn}, 0.006 \mathrm{Si}, 0.007 \mathrm{Al}, 1.85 \mathrm{Cr}, 3.35 \mathrm{Ni}, 0.42 \mathrm{Mo}, 0.089 \mathrm{~V}$ & $30 \mathrm{Cr} 2 \mathrm{Ni} 4 \mathrm{MoV}$ & $\mathrm{C}$ & & 368 & $8.18 \times 10^{-3}$ & & 0.113 & 0.83 & (1b) \\
\hline \multirow[t]{2}{*}{ [336] } & \multirow[t]{2}{*}{$0.009 \mathrm{C}, 1.5 \mathrm{Mn}, 0.42 \mathrm{Si}, 20.1 \mathrm{Cr}, 25.59 \mathrm{Ni}, 4.49 \mathrm{Mo}$} & \multirow{2}{*}{ 904L SASS } & $\mathrm{C}$ & & 443 & $1.35 \times 10^{-5}$ & & 0.240 & 0.59 & (1b) \\
\hline & & & & & & $4.16 \times 10^{-6}$ & & 0.250 & & (1b) \\
\hline
\end{tabular}


Table A1. Cont.

\begin{tabular}{|c|c|c|c|c|c|c|c|c|c|c|}
\hline Ref. & Chemical Composition * & Steel & Test $^{\dagger}$ & $d_{0} \ddagger$ & $Q_{h w} \S$ & $\kappa-K$ & $n$ & $m-m^{\prime}$ & $R_{\varepsilon}$ & Eqn. \\
\hline \multirow[t]{6}{*}{ [337] } & $0.09-0.15 \mathrm{C}, 0.4-0.41 \mathrm{Mn}, 0.29-0.43 \mathrm{Si}, 0.0026-0.0048 \mathrm{Al}, 1.3-1.33 \mathrm{Cr}$, & B & $\mathrm{C}$ & & 270 & $1.90 \times 10^{-2}$ & & 0.110 & & (1b) \\
\hline & $2.26-2.44 \mathrm{Ni}, 0.22-0.24 \mathrm{~V},(0.0014-0.0214) \mathrm{B}$ & B & $\mathrm{C}$ & & 270 & $2.30 \times 10^{-2}$ & & 0.100 & & (1b) \\
\hline & & B & $\mathrm{C}$ & & 270 & $2.00 \times 10^{-2}$ & & 0.110 & & (1b) \\
\hline & & B & $\mathrm{C}$ & & 270 & $1.00 \times 10^{-2}$ & & 0.140 & & (1b) \\
\hline & & B & $\mathrm{C}$ & & 270 & $1.20 \times 10^{-2}$ & & 0.130 & & (1b) \\
\hline & & $\mathrm{B}$ & $\mathrm{C}$ & & 270 & $6.30 \times 10^{-3}$ & & 0.160 & & (1b) \\
\hline [338] & $0.04 \mathrm{C}, 1.26 \mathrm{Mn}, 0.31 \mathrm{Si}, 16.05 \mathrm{Cr}, 10 \mathrm{Ni}, 2.01 \mathrm{Mo}$ & 316 & $\mathrm{C}$ & 55 & 368 & $1.90 \times 10^{-2}$ & & 0.090 & 0.65 & (1b) \\
\hline [339] & $0.4 \mathrm{C}, 0.7 \mathrm{Mn}, 0.3 \mathrm{Si}, 0.015 \mathrm{Al}, 0.9 \mathrm{Cr}$ & $40 \mathrm{Cr}$ & $\mathrm{C}$ & & & $2.40 \times 10^{-2}$ & & 0.125 & 0.82 & (11) \\
\hline [340] & $0.034 \mathrm{C}, 0.91 \mathrm{Mn}, 0.38 \mathrm{Si}, 13.18 \mathrm{Cr}, 5.11 \mathrm{Ni}, 0.86 \mathrm{Mo}$ & F6NM & $\mathrm{C}$ & & 458 & & & & 0.66 & \\
\hline [341] & $1.02 \mathrm{C}, 1.07 \mathrm{Mn}, 0.55 \mathrm{Si}, 1.49 \mathrm{Cr}$ & GCr15SiMn & $\mathrm{C}$ & & 304 & $3.46 \times 10^{-1}$ & & 0.057 & & $(4 b)$ \\
\hline [342] & $0.18 \mathrm{C}, 1.42 \mathrm{Mn}, 0.18 \mathrm{Si}, 0.13 \mathrm{Cr}, 0.89 \mathrm{Ni}, 0.5 \mathrm{Mo}$ & SA508-III & $\mathrm{C}$ & $<1200$ & 373 & $1.50 \times 10^{-3}$ & & 0.171 & & (1b) \\
\hline [343] & $0.052 \mathrm{C}, 1.63 \mathrm{Mn}, 0.2 \mathrm{Si}, 0.2 \mathrm{Cr}, 0.19 \mathrm{Ni}, 0.002 \mathrm{~V}$ & X70HD & $\mathrm{C}$ & & 358 & & & 0.026 & & (7b) \\
\hline \multirow[t]{2}{*}{ [344] } & 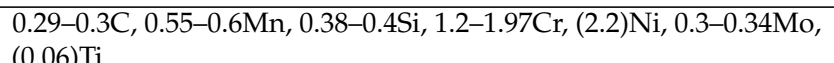 & 4135 & $\mathrm{C}$ & & 374 & $4.81 \times 10^{-3}$ & & 0.126 & & (1b) \\
\hline & & VCN200 & $\mathrm{C}$ & & 435 & $3.45 \times 10^{-3}$ & & 0.123 & & (1b) \\
\hline \multirow[t]{2}{*}{ [345] } & $0.3 \mathrm{C}, 2.2 \mathrm{Mn}, 0.2 \mathrm{Si}, 1.4 \mathrm{Cr}, 0.275 \mathrm{Mo}, 0.035 \mathrm{Nb}$ & $\begin{array}{c}\mathrm{MnCrNb} \\
\text { SPD1 }\end{array}$ & $\mathrm{C}$ & & 257 & $1.05 \times 10^{-3}$ & & 0.224 & & (1b) \\
\hline & & & & & & $4.87 \times 10^{-5}$ & & 0.293 & & (11) \\
\hline \multirow[t]{2}{*}{ [346] } & $0.015 \mathrm{C}, 0.7 \mathrm{Mn}, 0.5 \mathrm{Si}, 20 \mathrm{Cr}, 18 \mathrm{Ni}, 6.2 \mathrm{Mo}$ & $254 \mathrm{SMO}$ & $\mathrm{C}$ & 200 & 578 & $8.00 \times 10^{-2}$ & & 0.115 & 0.72 & (4b) \\
\hline & & & & & 578 & $5.00 \times 10^{-2}$ & & 0.129 & & (4b) \\
\hline \multirow[t]{6}{*}{ [139] } & $0.035-0.52 \mathrm{C}, 0.14-1.58 \mathrm{Mn}, 0.001-0.3 \mathrm{Si}, 0.01-0.122 \mathrm{Al}$ & $\mathrm{CMn}$ & $\mathrm{C}$ & 91 & 321 & & & 0.200 & 0.65 & (1a) \\
\hline & & $\mathrm{CMn}$ & $\mathrm{C}$ & 290 & 321 & & & 0.190 & & (1a) \\
\hline & & $\mathrm{CMn}$ & $\mathrm{C}$ & 98 & 300 & & & 0.200 & & (1a) \\
\hline & & $\mathrm{CMn}$ & $\mathrm{C}$ & 300 & 300 & & & 0.210 & & (1a) \\
\hline & & $\mathrm{CMn}$ & $\mathrm{C}$ & 50 & 333 & & & 0.150 & & (1a) \\
\hline & & $\mathrm{CMn}$ & $\mathrm{C}$ & 218 & 333 & & & 0.160 & & (1a) \\
\hline
\end{tabular}


Table A1. Cont.

\begin{tabular}{|c|c|c|c|c|c|c|c|c|c|c|}
\hline Ref. & Chemical Composition * & Steel & Test $^{\dagger}$ & $d_{0} \ddagger$ & $Q_{h w} \S$ & $\kappa-K$ & $n$ & $m-m^{\prime}$ & $R_{\varepsilon}$ & Eqn. \\
\hline \multirow[t]{2}{*}{ [347] } & \multirow[t]{2}{*}{$0.18 \mathrm{C}, 1.4 \mathrm{Mn}, 0.17 \mathrm{Si}, 0.022 \mathrm{Al}, 0.14 \mathrm{Cr}, 0.79 \mathrm{Ni}, 0.51 \mathrm{Mo}, 0.005 \mathrm{~V}$} & \multirow[t]{2}{*}{ SA508-III } & \multirow[t]{2}{*}{$\mathrm{C}$} & & 376 & $1.38 \times 10^{-3}$ & & 0.172 & & (1b) \\
\hline & & & & & 376 & $4.00 \times 10^{-4}$ & & 0.196 & & (1b) \\
\hline \multirow[t]{2}{*}{ [348] } & \multirow[t]{2}{*}{$0.52 \mathrm{C}, 0.33 \mathrm{Mn}, 0.2 \mathrm{Si}, 1.92 \mathrm{Cr}, 0.72 \mathrm{Ni}, 0.25 \mathrm{Mo}, 0.036 \mathrm{Nb}$} & \multirow[t]{2}{*}{ CrNimoNb } & $\mathrm{C}$ & & 386 & $1.07 \times 10^{-2}$ & & 0.100 & 0.37 & (1b) \\
\hline & & & & & 386 & $3.96 \times 10^{-3}$ & & 0.100 & & (1b) \\
\hline \multirow[t]{2}{*}{ [349] } & \multirow[t]{2}{*}{$0.06-0.5 \mathrm{C}, 0.42-0.68 \mathrm{Mn}, 0.12-0.2 \mathrm{Si}$} & Low $\mathrm{C}$ & $\mathrm{C}$ & 53 & 270 & $6.20 \times 10^{-3}$ & & & 0.53 & (1b) \\
\hline & & Med. C & $\mathrm{C}$ & 78 & 270 & $1.23 \times 10^{-2}$ & & & 0.54 & \\
\hline \multirow[t]{2}{*}{ [350] } & \multirow[t]{2}{*}{$0.053 \mathrm{C}, 1.567 \mathrm{Mn}, 0.31 \mathrm{Si}, 0.236 \mathrm{Ni}, 0.246 \mathrm{Mo}, 0.014 \mathrm{Ti}, 0.0012 \mathrm{~B}$} & \multirow[t]{2}{*}{$\mathrm{MnMoB}$} & $\mathrm{C}$ & & & $9.72 \times 10^{-4}$ & & 0.146 & & (1b) \\
\hline & & & & & & $8.65 \times 10^{-4}$ & & 0.146 & & (1b) \\
\hline
\end{tabular}

${ }^{*}[\mathrm{wt} . \%] ;{ }^{\dagger} \mathrm{C}$ : compression, T: torsion, R: rolling, TE: tension, M: multiple techniques; ${ }^{\ddagger}[\mu \mathrm{m}] ;{ }^{\S}\left[\mathrm{kJ} \cdot \mathrm{mol}^{-1}\right]$. TRIP: transformation induced plasticity, TWIP: twinning-induced plasticity steels, PH: precipitation hardening, HSLA: high-strength low-alloy. 


\section{References}

1. Jonas, J.J.; Sellars, C.M.; Tegart, W.J.M. Strength and structure under hot-working conditions. Metall. Rev. $1969,14,1-24$.

2. Anand, L. Constitutive equations for hot-working of metals. Int. J. Plast. 1985, 1, 213-231. [CrossRef]

3. Brown, S.B.; Kim, K.H.; Anand, L. An internal variable constitutive model for hot working of metals. Int. J. Plast. 1989, 5, 95-130. [CrossRef]

4. Jonas, J.J. Dynamic recrystallization-scientific curiosity or industrial tool? Mater. Sci. Eng. A 1994, 184, 155-165. [CrossRef]

5. Luton, M.J.; Sellars, C.M. Dynamic recrystallization in nickel and nickel-iron alloys during high temperature deformation. Acta Metall. 1969, 17, 1033-1043. [CrossRef]

6. Sellars, C.M. Dynamic recrystallization. Met. Forum 1981, 4, 75-80.

7. Sakai, T.; Jonas, J.J. Overview no. 35 Dynamic recrystallization: Mechanical and microstructural considerations. Acta Metall. 1984, 32, 189-209. [CrossRef]

8. Humphreys, F.J.; Hatherly, M. Recrystallisation and Related Annealing Phenomena, 1st ed.; Pergamon: Oxford, UK, 1996.

9. Sah, J.P.; Richardson, G.J.; Sellars, C.M. Quantitative correlation between high temperature strength \& the kinetics of dynamic recrystallization. Indian J. Technol. 1973, 11, 445-452.

10. Sakai, T.; Belyakov, A.; Kaibyshev, R.; Miura, H.; Jonas, J.J. Dynamic and post-dynamic recrystallization under hot, cold and severe plastic deformation conditions. Prog. Mater. Sci. 2014, 60, 130-207. [CrossRef]

11. Gottstein, G.; Brünger, E.; Frommert, M.; Goerdeler, M.; Zeng, M. Prediction of the critical conditions for dynamic recrystallization in metals. Z. Für Met. 2003, 94, 628-635. [CrossRef]

12. Busso, E.P. A continuum theory for dynamic recrystallization with microstructure-related length scales. Int. J. Plast. 1998, 14, 319-353. [CrossRef]

13. Wray, P.J. Onset of recrystallization during the tensile deformation of austenitic iron at intermediate strain rates. Metall. Trans. A 1975, 6, 1197-1203. [CrossRef]

14. Poliak, E.I.; Jonas, J.J. A one-parameter approach to determining the critical conditions for the initiation of dynamic recrystallization. Acta Mater. 1996, 44, 127-136. [CrossRef]

15. Sakai, T. Dynamic recrystallization microstructures under hot working conditions. J. Mater. Process. Technol. 1995, 53, 349-361. [CrossRef]

16. Belyakov, A.; Miura, H.; Sakai, T. Dynamic recrystallization under warm deformation of a 304 type austenitic stainless steel. Mater. Sci. Eng. A 1998, 255, 139-147. [CrossRef]

17. Rios, P.R.; Siciliano, F.; Zschommler Sandim, H.R.; Plaut, R.L.; Padilha, A.F. Nucleation and growth during recrystallization. Mater. Res. 2005, 8, 225-238. [CrossRef]

18. Doherty, R.D.; Hughes, D.A.; Humphreys, F.J.; Jonas, J.J.; Juul Jensen, D.; Kassner, M.E.; King, W.E.; McNelley, T.R.; McQueen, H.J.; Rollett, A.D. Current issues in recrystallization: A review. Mater. Sci. Eng. A 1997, 238, 219-274. [CrossRef]

19. Ponge, D.; Gottstein, G. Necklace formation during dynamic recrystallization: Mechanisms and impact on flow behavior. Acta Mater. 1998, 46, 69-80. [CrossRef]

20. Sah, J.P.; Richardson, G.J.; Sellars, C.M. Grain-size effects during dynamic recrystallization of nickel. Met. Sci. 1974, 8, 325-331. [CrossRef]

21. Roberts, W.; Boden, H.; Ahlblom, B. Dynamic recrystallization kinetics. Met. Sci. 1979, 13, 195-205. [CrossRef]

22. Ouchi, C.; Okita, T. Dynamic recrystallization behavior of austenite in Nb-bearing high strength low alloy steels and stainless steel. Trans. Iron Steel Inst. Japan 1982, 22, 543-551. [CrossRef]

23. Lenard, J.G.; Pietrzyk, M.; Cser, L. Mathematical and Physical Simulation of the Properties of Hot Rolled Products, 1st ed.; Elsevier Science Ltd.: Oxford, UK, 1999.

24. Derby, B. The dependence of grain size on stress during dynamic recrystallisation. Acta Metall. Mater. 1991, 39, 955-962. [CrossRef]

25. Weiss, I.; Jonas, J.J. Interaction between recrystallization and precipitation during the high temperature deformation of HSLA steels. Metall. Trans. A 1979, 10, 831-840. [CrossRef]

26. Stewart, G.R.; Jonas, J.J.; Montheillet, F. Kinetics and critical conditions for the initiation of dynamic recrystallization in 304 stainless steel. ISIJ Int. 2004, 44, 1581-1589. [CrossRef] 
27. Weiss, I.; Sakai, T.; Jonas, J.J. Effect of test method on transition from multiple to single peak dynamic recrystallization. Met. Sci. J. 1984, 18, 77-84. [CrossRef]

28. Siciliano, F., Jr.; Jonas, J.J. Mathematical modeling of the hot strip rolling of microalloyed Nb, multiply-alloyed Cr-Mo, and plain C-Mn steels. Metall. Mater. Trans. A 2000, 31, 511-530. [CrossRef]

29. Poliak, E.I.; Jonas, J.J. Initiation of dynamic recrystallization in constant strain rate hot deformation. ISIJ Int. 2003, 43, 684-691. [CrossRef]

30. Zener, C.; Hollomon, J.H. Effect of strain rate upon plastic flow of steel. J. Appl. Phys. 1944, 15, $22-32$. [CrossRef]

31. Varela-Castro, G.; Cabrera, J.M.; Prado, J.M. On the onset of dynamic recrystallization in steels. Adv. Mater. Res. 2012, 409, 431-436. [CrossRef]

32. le Bon, A.; Rofes-Vernis, J.; Rossard, C. Recrystallisation et précipitation provoquées par la déformation à chaud: Cas d'un acier de construction soudable au niobium. Mémoires Sci. La Rev. Métallurgie 1973, 70, 577-588.

33. Sellars, C.M. Physical metallurgy of hot working. In Hot Working and Forming Processes; Met Soc: Sheffield, UK, 1980; pp. 3-15.

34. Rossard, C.; Blain, P. Evolution de la structure de l'acier sous l'effet de la déformation plastique à chaud Mémoires Sci. La Rev. Métallurgie 1959, 56, 285-300.

35. Glover, G.; Sellars, C.M. Recovery and recrystallization during high temperature deformation of $\alpha$-iron. Metall. Trans. 1973, 4, 765-775. [CrossRef]

36. Maki, T.; Akasaka, K.; Okuno, K.; Tamura, I. Dynamic recrystallization of austenite in 18-8 stainless steel and $18 \mathrm{Ni}$ maraging steel and its related phenomena. Tetsu-to-Hagané 1980, 66, 1659-1668. [CrossRef]

37. Maki, T.; Akasaka, K.; Okuno, K.; Tamura, I. Dynamic recrystallization of austenite in 18-8 stainless steel and 18 Ni maraging steel. Trans. Iron Steel Inst. Japan 1982, 22, 253-261. [CrossRef]

38. Ueki, M.; Horie, S.; Nakamura, T. Factors affecting dynamic recrystallization of metals and alloys. Mater. Sci. Technol. 1987, 3, 329-337. [CrossRef]

39. Dehghan-Manshadi, A.; Barnett, M.R.; Hodgson, P.D. Recrystallization in AISI 304 austenitic stainless steel during and after hot deformation. Mater. Sci. Eng. A 2008, 485, 664-672. [CrossRef]

40. Dehghan-Manshadi, A.; Barnett, M.R.; Hodgson, P.D. Hot deformation and recrystallization of austenitic stainless steel: Part I. Dynamic recrystallization. Metall. Mater. Trans. A 2008, 39, 1359-1370. [CrossRef]

41. Stewart, G.R.; Elwazri, A.M.; Yue, S.; Jonas, J.J. Modelling of dynamic recrystallisation kinetics in austenitic stainless and hypereutectoid steels. Mater. Sci. Technol. 2006, 22, 519-524. [CrossRef]

42. Beladi, H.; Cizek, P.; Hodgson, P.D. Dynamic recrystallization of austenite in Ni-30 pct Fe model alloy: Microstructure and texture evolution. Metall. Mater. Trans. A 2009, 40, 1175-1189. [CrossRef]

43. Laasraoui, A.; Jonas, J.J. Prediction of steel flow stresses at high temperatures and strain rates. Metall. Trans. A 1991, 22, 1545-1558. [CrossRef]

44. Mintz, B.; Jonas, J.J.; Abushosha, R. Effect of grain refinement and grain coarsening on shapes of dynamic recrystallisation flow curves for C-Mn-Al steels. Mater. Sci. Technol. 1991, 7, 904-913. [CrossRef]

45. Mintz, B.; Abushosha, R.; Jonas, J.J. Influence of dynamic recrystallisation on the tensile ductility of steels in the temperature range 700 to $1150{ }^{\circ} \mathrm{C}$. ISIJ Int. 1992, 32, 241-249. [CrossRef]

46. Medina, S.F.; Hernandez, C.A. General expression of the Zener-Hollomon parameter as a function of the chemical composition of low alloy and microalloyed steels. Acta Mater. 1996, 44, 137-148. [CrossRef]

47. Medina, S.F.; Hernandez, C.A. The influence of chemical composition on peak strain of deformed austenite in low alloy and microalloyed steels. Acta Mater. 1996, 44, 149-154. [CrossRef]

48. Hernandez, C.A.; Medina, S.F.; Ruiz, J. Modelling austenite flow curves in low alloy and microalloyed steels. Acta Mater. 1996, 44, 155-163. [CrossRef]

49. Medina, S.F.; Hernandez, C.A. Modelling of the dynamic recrystallization of austenite in low alloy and microalloyed steels. Acta Mater. 1996, 44, 165-171. [CrossRef]

50. Kim, S.-I.; Yoo, Y.-C. Dynamic recrystallization behavior of AISI 304 stainless steel. Mater. Sci. Eng. A 2001, 311, 108-113. [CrossRef]

51. Kowalski, B.; Sellars, C.M.; Pietrzyk, M. Development of a computer code for the interpretation of results of hot plane strain compression tests. ISIJ Int. 2000, 40, 1230-1236. [CrossRef]

52. Minami, K.; Siciliano, F., Jr.; Maccagno, T.M.; Jonas, J.J. Mathematical modeling of mean flow stress during the hot strip rolling of $\mathrm{Nb}$ steels. ISIJ Int. 1996, 36, 1507-1515. [CrossRef] 
53. Fernández, A.I.; Uranga, P.; López, B.; Rodriguez-Ibabe, J.M. Dynamic recrystallization behavior covering a wide austenite grain size range in $\mathrm{Nb}$ and $\mathrm{Nb}-\mathrm{Ti}$ microalloyed steels. Mater. Sci. Eng. A 2003, 361, 367-376. [CrossRef]

54. Elwazri, A.M.; Wanjara, P.; Yue, S. Dynamic recrystallization of austenite in microalloyed high carbon steels. Mater. Sci. Eng. A 2003, 339, 209-215. [CrossRef]

55. Pereda, B.; Fernández, A.I.; López, B.; Rodriguez-Ibabe, J.M. Effect of Mo on dynamic recrystallization behavior of Nb-Mo microalloyed steels. ISIJ Int. 2007, 47, 860-868. [CrossRef]

56. Solhjoo, S.; Ebrahimi, R. Prediction of no-recrystallization temperature by simulation of multi-pass flow stress curves from single-pass curves. J. Mater. Sci. 2010, 45, 5960-5966. [CrossRef]

57. Zhu, G.-H.; Subramanian, S.V. Recrystallization behavior design for controlling grain size in strip rolling process. J. Iron Steel Res. Int. 2008, 15, 39-44. [CrossRef]

58. San Martín, G.E.; Núñez Pettinari, S.I.; Ruzzante, J.E.; Merlone, G.F. Prediction of the onset of dynamic recrystallization in different types of steels. Scr. Metall. Mater. 1992, 26, 405-410. [CrossRef]

59. San Martín, G.E.; Ruzzante, J.E. Characterization of true stress-true strain curves obtained by hot deformation of different types of steels. Scr. Metall. Mater. 1993, 29, 919-924. [CrossRef]

60. Kuc, D.; Niewielski, G.; Cwajna, J. Influence of deformation parameters and initial grain size on the microstructure of austenitic steels after hot-working processes. Mater. Charact. 2006, 56, 318-324. [CrossRef]

61. Panigrahi, B.K. Processing of low carbon steel plate and hot strip-An overview. Bull. Mater. Sci. 2001, 24, 361-371. [CrossRef]

62. Sun, W.P.; Hawbolt, E.B. Comparison between static and metadynamic recrystallization-An application to the hot rolling of steels. ISIJ Int. 1997, 37, 1000-1009. [CrossRef]

63. Yanagida, A.; Yanagimoto, J. Regression method of determining generalized description of flow curve of steel under dynamic recrystallization. ISIJ Int. 2005, 45, 858-866. [CrossRef]

64. Lin, Y.C.; Chen, M.-S.; Zhong, J. Effects of deformation temperatures on stress/strain distribution and microstructural evolution of deformed 42CrMo steel. J. Mater. Des. 2009, 30, 908-913. [CrossRef]

65. Yue, C.-X.; Zhang, L.-W.; Liao, S.-L.; Pei, J.-B.; Gao, H.-J.; Jia, Y.-W.; Lian, X.-J. Research on the dynamic recrystallization behavior of GCr15 steel. Mater. Sci. Eng. A 2009, 499, 177-181. [CrossRef]

66. Lin, Y.C.; Liu, G. A new mathematical model for predicting flow stress of typical high-strength alloy steel at elevated high temperature. Comput. Mater. Sci. 2010, 48, 54-58. [CrossRef]

67. Yin, F.; Hua, L.; Mao, H.; Han, X.; Qian, D.; Zhang, R. Microstructural modeling and simulation for GCr15 steel during elevated temperature deformation. Mater. Des. 2014, 55, 560-573. [CrossRef]

68. Solhjoo, S. Determination of critical strain for initiation of dynamic recrystallization. Mater. Des. 2010, 31, 1360-1364. [CrossRef]

69. Lin, Y.C.; Chen, M.-S.; Zhong, J. Constitutive modeling for elevated temperature flow behavior of $42 \mathrm{CrMo}$ steel. Comput. Mater. Sci. 2008, 42, 470-477. [CrossRef]

70. Mandal, S.; Rakesh, V.; Sivaprasad, P.V.; Venugopal, S.; Kasiviswanathan, K.V. Constitutive equations to predict high temperature flow stress in a Ti-modified austenitic stainless steel. Mater. Sci. Eng. A 2009, 500, 114-121. [CrossRef]

71. Senuma, T.; Yada, H.; Matsumura, Y.; Futamura, T. Structure of austenite of carbon steels in high speed hot working processes. Tetsu-to-Hagané 1984, 70, 2112-2219. [CrossRef]

72. Anan, G.; Nakajima, S.; Miyahara, M.; Nanba, S.; Umemoto, M.; Hiramatsu, A.; Moriya, A.; Watanabe, T. A model for recovery and recrystallization of hot deformed austenite considering structural heterogeneity. ISIJ Int. 1992, 32, 261-266. [CrossRef]

73. Nanba, S.; Kitamura, M.; Shimada, M.; Katsumata, M.; Inoue, T.; Imamura, H.; Maeda, Y.; Hattori, S. Prediction of microstructure the through-thickness during and after hot rolling. ISIJ Int. 1992, 32, 377-386. [CrossRef]

74. Wang, F.; Lenard, J.G. The constitutive behaviour of a Nb-V HSLA steel in the temperature range of 900 to $975^{\circ} \mathrm{C}$. Steel Res. 1991, 62, 66-71. [CrossRef]

75. Yang, Y.; Yan, Q.-Z.; Ge, C.-C. Hot deformation behavior of modified CNS-II F/M steel. J. Iron Steel Res. Int. 2012, 19, 60-65. [CrossRef]

76. Cingara, A.; McQueen, H.J. New formula for calculating flow curves from high temperature constitutive data for 300 austenitic steels. J. Mater. Process. Technol. 1992, 36, 31-42. [CrossRef] 
77. McQueen, H.J.; Yue, S.; Ryan, N.D.; Fry, E. Hot working characteristics of steels in austenitic state. J. Mater. Process. Technol. 1995, 53, 293-310. [CrossRef]

78. McQueen, H.J.; Ryan, N.D. Constitutive analysis in hot working. Mater. Sci. Eng. A 2002, 322, 43-63. [CrossRef]

79. Evangelista, E.; Masini, M.; El Mehtedi, M.; Spigarelli, S. Hot working and multipass deformation of a $41 \mathrm{Cr} 4$ steel. J. Alloys Compd. 2004, 378, 151-154. [CrossRef]

80. Sandström, R.; Lagneborg, R. A model for hot working occurring by recrystallization. Acta Metall. 1975, 23, 387-398. [CrossRef]

81. Roberts, W.; Ahlblom, B. A nucleation criterion for dynamic recrystallization during hot working. Acta Metall. 1978, 26, 801-813. [CrossRef]

82. Brechet, Y.; Estrin, Y.; Reusch, F. A dynamic recrystallisation criterion: DRX map. Scr. Mater. 1998, 39, 1191-1197. [CrossRef]

83. Barnett, M.R.; Kelly, G.L.; Hodgson, P.D. Predicting the critical strain for dynamic recrystallization using the kinetics of static recrystallization. Scr. Mater. 2000, 43, 365-369. [CrossRef]

84. Barnett, M.R.; Kelly, G.L.; Hodgson, P.D. Inferring dynamic recrystallization in ferrite using the kinetics of static recrystallization. Metall. Mater. Trans. A 2002, 33, 1893-1900. [CrossRef]

85. Kolmogorov, A.N. On the statistical theory of metal crystallization. Izv. Akad. Nauk SSSR Ser. Mat. 1937, 3, 355-360.

86. Johnson, W.A.; Mehl, R.F. Reaction kinetics in processes of nucleation and growth. Trans. AIME 1939, 135, 416-442.

87. Avrami, M. Kinetics of phase change. I. General theory. J. Chem. Phys. 1939, 7, 1103-1112. [CrossRef]

88. Avrami, M. Kinetics of phase change. II Transformation-time relations for random distribution of nuclei. J. Chem. Phys. 1940, 8, 212-224. [CrossRef]

89. Cahn, J.W. The kinetics of grain boundary nucleated reactions. Acta Metall. 1956, 4, 449-459. [CrossRef]

90. Bergström, Y. A dislocation model for the stress-strain behaviour of polycrystalline a-Fe with special emphasis on the variation of the densities of mobile and immobile dislocations. Mater. Sci. Eng. 1970, 5, 193-200. [CrossRef]

91. Mecking, H.; Kocks, U.F. Kinetics of flow and strain-hardening. Acta Metall. 1981, 29, 1865-1875. [CrossRef]

92. Kocks, U.F.; Mecking, H. Physics and phenomenology of strain hardening: The FCC case. Prog. Mater. Sci. 2003, 48, 171-273. [CrossRef]

93. Estrin, Y.; Mecking, H. A unified phenomenological description of work hardening and creep based on one-parameter models. Acta Metall. 1984, 32, 57-70. [CrossRef]

94. Sommitsch, C.; Mitter, W. On modelling of dynamic recrystallisation of fcc materials with low stacking fault energy. Acta Mater. 2006, 54, 357-375. [CrossRef]

95. Srolovitz, D.J.; Grest, G.S.; Anderson, M.P. Computer simulation of recrystallization-I. Homogeneous nucleation and growth. Acta Metall. 1986, 34, 1833-1845. [CrossRef]

96. Srolovitz, D.J.; Grest, G.S.; Anderson, M.P.; Rollett, A.D. Computer simulation of recrystallization-II. Heterogeneous nucleation and growth. Acta Metall. 1988, 36, 2115-2128. [CrossRef]

97. Rollett, A.D.; Luton, M.J.; Srolovitz, D.J. Microstructural simulation of dynamic recrystallization. Acta Metall. Mater. 1992, 40, 43-55. [CrossRef]

98. Peczak, P. A Monte Carlo study of influence of deformation temperature on dynamic recrystallization. Acta Metall. Mater. 1995, 43, 1279-1291. [CrossRef]

99. Goetz, R.L.; Seetharaman, V. Modeling dynamic recrystallization using cellular automata. Scr. Mater. 1998, 38, 405-413. [CrossRef]

100. Ding, R.; Guo, Z.X. Coupled quantitative simulation of microstructural evolution and plastic flow during dynamic recrystallization. Acta Mater. 2001, 49, 3163-3175. [CrossRef]

101. Kugler, G.; Turk, R. Modeling the dynamic recrystallization under multi-stage hot deformation. Acta Mater. 2004, 52, 4659-4668. [CrossRef]

102. Yazdipour, N.; Davies, C.H.J.; Hodgson, P.D. Microstructural modeling of dynamic recrystallization using irregular cellular automata. Comput. Mater. Sci. 2008, 44, 566-576. [CrossRef]

103. Takaki, T.; Hisakuni, Y.; Hirouchi, T.; Yamanaka, A.; Tomita, Y. Multi-phase-field simulations for dynamic recrystallization. Comput. Mater. Sci. 2009, 45, 881-888. [CrossRef] 
104. Frost, H.J.; Thompson, C.V.; Howe, C.L.; Whang, J. A two-dimensional computer simulation of capillarity-driven grain growth: Preliminary results. Scr. Metall. 1988, 22, 65-70. [CrossRef]

105. Weygand, D.; Bréchet, Y.; Lépinoux, J. A vertex dynamics simulation of grain growth in two dimensions. J. Philos. Mag. Part B 1998, 78, 329-352. [CrossRef]

106. Logé, R.; Bernacki, M.; Resk, H.; Delannay, L.; Digonnet, H.; Chastel, Y.; Coupez, T. Linking plastic deformation to recrystallization in metals using digital microstructures. Philos. Mag. 2008, 88, 3691-3712. [CrossRef]

107. Perdrix, C. Caractéristiques d'écoulement plastique du métal dans les conditions du T.A.B. à chaud. Comm. Des. Ommunautés Eur. IRSID Saint-Germain-Em-Laye Fr. 1987, EUR8697FR, 58-74.

108. Kirihata, A.; Siciliano, F., Jr.; Maccagno, T.M.; Jonas, J.J. Mathematical modelling of mean flow stress during the hot strip rolling of multiply-alloyed medium carbon steels. ISIJ Int. 1998, 38, 187-195. [CrossRef]

109. Ryan, N.D.; McQueen, H.J. Dynamic softening mechanisms in 304 austenitic stainless steel. Can. Metall. Q. 1990, 29, 147-162. [CrossRef]

110. Hart, E.W. A phenomenological theory for plastic deformation of polycrystalline metals. Acta Metall. 1970, 18, 599-610. [CrossRef]

111. Poliak, E.I.; Jonas, J.J. Critical Strain for Dynamic Recrystallization in Variable Strain Rate Hot Deformation. ISIJ Int. 2003, 43, 692-700. [CrossRef]

112. Kocks, U.F. Laws for work-hardening and low-temperature creep. J. Eng. Mater. Technol. Trans. ASME 1976, 98, 76-85. [CrossRef]

113. Najafizadeh, A.; Jonas, J.J. Predicting the critical stress for initiation of dynamic recrystallization. ISIJ Int. 2006, 46, 1679-1684. [CrossRef]

114. Gottstein, G.; Frommert, M.; Goerdeler, M.; Schäfer, N. Prediction of the critical conditions for dynamic recrystallization in the austenitic steel 800H. Mater. Sci. Eng. A 2004, 387-389, 604-608. [CrossRef]

115. Estrin, Y.; Tóth, L.S.; Molinari, A.; Bréchet, Y. A dislocation-based model for all hardening stages in large strain deformation. Acta Mater. 1998, 46, 5509-5522. [CrossRef]

116. Mughrabi, H. Dislocation wall and cell structures and long-range internal stresses in deformed metal crystals. Acta Metall. 1983, 31, 1367-1379. [CrossRef]

117. Mughrabi, H. A two-parameter description of heterogeneous dislocation distributions in deformed metal crystals. Mater. Sci. Eng. 1987, 85, 15-31. [CrossRef]

118. Müller, M.; Zehetbauer, M.; Borbély, A.; Ungár, T. Stage IV work hardening in cell forming materials, part I: Features of the dislocation structure determined by X-ray line broadening. Scr. Mater. 1996, 35, 1461-1466. [CrossRef]

119. Bambach, M. Implications from the Poliak-Jonas criterion for the construction of flow stress models incorporating dynamic recrystallization. Acta Mater. 2013, 61, 6222-6233. [CrossRef]

120. Ebrahimi, R.; Solhjoo, S. Characteristic points of stress-strain curve at high temperature. Int. J. ISSI 2007, 4, 24-27.

121. Ebrahimi, R.; Zahiri, S.H.; Najafizadeh, A. Mathematical modelling of the stress-strain curves of Ti-IF steel at high temperature. J. Mater. Process. Technol. 2006, 171, 301-305. [CrossRef]

122. Cingara, A.; McQueen, H.J. New method for determining sinh constitutive constants for high temperature deformation of 300 austenitic steels. J. Mater. Process. Technol. 1992, 36, 17-30. [CrossRef]

123. Mirzadeh, H.; Najafizadeh, A. Prediction of the critical conditions for initiation of dynamic recrystallization. Mater. Des. 2010, 31, 1174-1179. [CrossRef]

124. Solhjoo, S. Determination of flow stress and the critical strain for the onset of dynamic recrystallization using a hyperbolic tangent function. Mater. Des. 2014, 54, 390-393. [CrossRef]

125. Chen, F.; Feng, G.; Cui, Z. Mathematical modeling of critical condition for dynamic recrystallization. Procedia Eng. 2014, 81, 486-491. [CrossRef]

126. Jonas, J.J.; Ghosh, C.; Quelennec, X.; Basabe, V.V. The critical strain for dynamic transformation in hot deformed austenite. ISIJ Int. 2013, 53, 145-151. [CrossRef]

127. Quelennec, X.; Jonas, J.J. Simulation of austenite flow curves under industrial rolling conditions using a physical dynamic recrystallization model. ISIJ Int. 2012, 52, 1145-1152. [CrossRef]

128. Lohmar, J.; Bambach, M. Influence of different interpolation techniques on the determination of the critical conditions for the onset of dynamic recrystallisation. Mater. Sci. Forum 2013, 762, 331-336. [CrossRef] 
129. Duchon, J. Interpolation des fonctions de deux variables suivant le principe de la flexion des plaques minces. RAIRO Anal. Numérique 1976, 10, 5-12. [CrossRef]

130. Jonas, J.J.; Quelennec, X.; Jiang, L.; Martin, E. The Avrami kinetics of dynamic recrystallization. Acta Mater. 2009, 57, 2748-2756. [CrossRef]

131. Bhadeshia, H.K.D.H.; Honeycombe, R. Steels: Microstructure and Properties, 3rd ed.; Butterworth-Heinemann: Oxford, UK, 2006.

132. Kong, L.X.; Hodgson, P.D.; Collinson, D.C. Modelling the effect of carbon content on hot strength of steels using a modified artificial neural network. ISIJ Int. 1998, 38, 1121-1129. [CrossRef]

133. Escobar, F.; Cabrera, J.M.; Prado, J.M. Effect of carbon content on plastic flow behaviour of plain carbon steels at elevated temperature. Mater. Sci. Technol. 2003, 19, 1137-1147. [CrossRef]

134. Cabañas, N.; Akdut, N.; Penning, J.; De Cooman, B.C. High-temperature deformation properties of austenitic Fe-Mn alloys. Metall. Mater. Trans. A 2006, 37, 3305-3315. [CrossRef]

135. Varela-Castro, G. Efecto de los Contenidos de C, Si y Mn en el Comportamiento a Fluencia en Caliente de Aceros de Construcción al Carbono. Aplicación a la Obtención de Grano Ultra-Fino en Productos Largos Laminados. Ph.D. Thesis, Universitat Politècnica de Catalunya, Barcelona, Spain, 2013.

136. Cabrera, J.M.; Al Omar, A.; Jonas, J.J.; Prado, J.M. Modelling the flow behaviour of a medium carbon microalloyed steel under hot working conditions. Metall. Mater. Trans. A 1997, 28, 2233-2243. [CrossRef]

137. Frost, H.J.; Ashby, M. Deformation-Mechanism Maps. The Plasticity and Creep of Metals and Ceramics, 1st ed.; Pergamon Press: Oxford, UK, 1982.

138. Bakker, H.; Bonzel, H.P.; Bruff, C.M.; Dayananda, M.A.; Gust, W.; Horváth, J.; Kaur, I.; Kidson, G.V.; Le Claire, A.D.; Mehrer, H.; et al. Diffusion in Solid Metals and Alloys. In Landolt-Börnstein: Numerical Data and Functional Relationships in Science and Technology, 26, 1st ed.; Springer: Berlin, Germany, 1990.

139. Siyasiya, C.W.; Stumpf, W.E. Constitutive constants for hot working of steels: The critical strain for dynamic recrystallisation in C-Mn steels. J. Mater. Eng. Perform. 2015, 24, 468-476. [CrossRef]

140. Xu, Y.B.; Yu, Y.M.; Xiao, B.L.; Liu, Z.Y.; Wang, G.D. Modelling of microstructure evolution during hot rolling of a high-Nb HSLA steel. J. Mater. Sci. 2010, 45, 2580-2590. [CrossRef]

141. le Bon, A.; Rofes-Vernis, J.; Rossard, C. Recrystallization and Precipitation during Hot Working of a Nb-Bearing HSLA Steel. Met. Sci. J. 1975, 9, 36-40. [CrossRef]

142. Nazábal, J.L.; Urcola, J.J.; Fuentes, M. High-temperature deformation characteristics of free-machining steels. Met. Technol. 1982, 9, 323-326. [CrossRef]

143. Senuma, T.; Takemoto, Y. Model for Predicting the Microstructural Evolution of Extralow Carbon Steels. ISIJ Int. 2008, 48, 1635-1639. [CrossRef]

144. Ruibal, E.; Urcola, J.J.; Fuentes, M. Transition from regular oscillations inflow stress to single peak during high-temperature torsional deformation of a low-alloy steel. Met. Technol. 1984, 11, 189-195. [CrossRef]

145. Nazábal, J.L.; Urcola, J.J.; Fuentes, M. The transition from multiple- to single-peak recrystallization during the hot working of austenite. Mater. Sci. Eng. 1987, 86, 93-103. [CrossRef]

146. Sellars, C.M. Modelling microstructural development during hot rolling. Mater. Sci. Technol. 1990, 6, 1072-1081. [CrossRef]

147. Ryan, N.D.; McQueen, H.J. Comparison of dynamic softening in 301, 304, 316 and 317 stainless steels. High Temp. Technol. 1990, 8, 185-200. [CrossRef]

148. Ryan, N.D.; McQueen, H.J. Work hardening, strength and ductility in the hot working of 304 austenitic stainless steel. High Temp. Technol. 1990, 8, 27-44. [CrossRef]

149. Samuel, F.H.; Yue, S.; Jonas, J.J.; Barnes, K.R. Effect of dynamic recrystallization on microstructural evolution during strip rolling. ISIJ Int. 1990, 30, 216-225. [CrossRef]

150. Barbosa, R.A.N.M.; Braga, H.C. Analysis of the occurrence of dynamic recrystallization in hot rolling by modeling of the stress-strain curve. ISIJ Int. 1992, 32, 257-259. [CrossRef]

151. Laasraoui, A.; Jonas, J.J. Prediction of temperature distribution, flow stress and microstructure during the multipass hot rolling of steel plate and strip. ISIJ Int. 1991, 31, 95-105. [CrossRef]

152. Devadas, C.; Samarasekera, I.V.; Hawbolt, E.B. The thermal and metallurgical state of steel strip during hot rolling: Part I. Characterization of heat transfer. Metall. Trans. A 1991, 22, 307-319. [CrossRef]

153. Samarasekera, I.V.; Hawbolt, E.B. Overview of modelling the microstructural state of steel strip during hot rolling. J. S. Afr. Inst. Min. Metall. 1995, 95, 157-165. 
154. Bowden, J.W.; Samuel, F.H.; Jonas, J.J. Effect of interpass time on austenite grain refinement by means of dynamic recrystallization of austenite. Metall. Trans. A 1991, 22, 2947-2957. [CrossRef]

155. Anelli, E. Application of mathematical modelling to hot rolling and controlled cooling of wire rods and bars. ISIJ Int. 1992, 32, 440-449. [CrossRef]

156. Pussegoda, L.N.; Hodgson, P.D.; Jonas, J.J. Design of dynamic recrystallisation controlled rolling schedules for seamless tube rolling. Mater. Sci. Technol. 1992, 8, 63-71. [CrossRef]

157. Roucoules, C. Dynamic and Metadynamic Recrystallization in HSLA Steels. Ph.D. Thesis, McGill University, Montreal, QC, Canada, 1992.

158. Xu, Y.; Gu, Q.; Wang, D.; Gu, J.; Qu, T. Dynamic mechanical behaviours of high Mo austenitic stainless stee during hot deformation. Acta Metall. Sin. (Engl. Lett. Ser. B) 1992, 5, 60-64.

159. Medina, S.F.; Lopez, V. Static recrystallization in austenite and its influence on microstructural changes in C-Mn steel and vanaidum microalloyed steel at the hot strip mill. ISIJ Int. 1993, 33, 605-614. [CrossRef]

160. Xu, Y.; Hou, D.; Wang, D.; Xu, W.-P.; Huang, T. Advances in Hot Deformation Textures and Microstructures; Jonas, J.J., Bieler, T.R., Bowman, K.J., Eds.; Minerals, Metals \& Materials Society: Warrendale, PA, USA, 1994; pp. 183-194.

161. Elwazri, A.M. Processing and Properties of High Carbon Microallyed Steels. Ph.D. Thesis, McGill University, Montreal, QC, Canada, 2004.

162. Roucoules, C.; Hodgson, P.D.; Yue, S.; Jonas, J.J. Softening and microstructural change following the dynamic recrystallization of austenite. Metall. Mater. Trans. A 1994, 25, 389-400. [CrossRef]

163. Pandi, R.; Yue, S. Dynamic transformation of austenite to ferrite in low carbon steel. ISIJ Int. 1994, 34, $270-279$. [CrossRef]

164. Karjalainen, L.P.; Maccagno, T.M.; Jonas, J.J. Softening and flow stress behaviour of Nb microalloyed steels during hot rolling simulation. ISIJ Int. 1995, 35, 1523-1531. [CrossRef]

165. Glowacki, M.; Kuziak, R.; Malinowski, Z.; Pietrzyk, M. Modelling of heat transfer, plastic flow and microstructural evolution during shape rolling. J. Mater. Process. Technol. 1995, 53, 159-166. [CrossRef]

166. Pietrzyk, M.; Kuziak, R. Application of the internal variable approach to the simulation of microstructural phenomena in hot forming of eutecloid steel. In Proceedings of the 4th European Conference on Advanced Materials and Processes EUROMAT95, Padova, Italy, 25-28 September 1995; pp. 239-244.

167. Cabrera, J.M. Caracterización Mecánico-Metalúrgica de la Conformación en Caliente Del Acero Microaleado de Medio Carbono 38MnSiVS5. Ph.D. Thesis, Universitat Politècnica de Catalunya, Barcelona, Spain, 1995.

168. Maccagno, T.M.; Jonas, J.J.; Hodgson, P.D. Spreadsheet modelling of grain size evolution during rod rolling. ISIJ Int. 1996, 36, 720-728. [CrossRef]

169. Colás, R. A model for the hot deformation of low-carbon steel. J. Mater. Process. Technol. 1996, 62, $180-184$. [CrossRef]

170. Kuziak, R.; Glowacki, M.; Pietrzyk, M. Modelling of plastic flow, heat transfer and microstructural evolution during rolling of eutectoid steel rods. J. Mater. Process. Technol. 1996, 60, 589-596. [CrossRef]

171. Wakita, J.-I.; Takahashi, M.; Haji, J.; Kawano, O.; Esaka, K. Prediction of structure change of austenite of low carbon steels. Tetsu-to-Hagané 1996, 82, 617-622. [CrossRef]

172. Cabrera, J.M.; Al Omar, A.; Prado, J.M. Simulación de la fluencia en caliente de un acero microaleado de medio carbono. (Parte III. Ecuaciones constitutivas). Rev. Met. 1997, 33, 215-228. [CrossRef]

173. Kong, L.X.; Hodgson, P.D. The application of constitutive and artificial neural network models to predict the hot strength of steels. ISIJ Int. 1999, 39, 991-998. [CrossRef]

174. Siciliano, F., Jr. Mathematical Modelling of the Hot Strip Rolling of Nb Microalloyed Steels. Ph.D. Thesis, McGill University, Montreal, QC, Canada, 1999.

175. Pauskar, P.; Shivpuri, R. Microstructure and mechanics interaction in the modeling of hot rolling of rods. CIRP Ann. Manuf. Technol. 1999, 48, 191-194. [CrossRef]

176. Jonas, J.J. The hot strip mill as an experimental tool. ISIJ Int. 2000, 40, 731-738. [CrossRef]

177. Schindler, I.; Hadasik, E. A new model describing the hot stress-strain curves of HSLA steel at high deformation. J. Mater. Process. Technol. 2000, 106, 131-135. [CrossRef]

178. Xu, Y.-R.; Chen, L.-S.; Wang, D.-Y.; Jin, L. High temperature softening behaviors and flow stress model for a high molybdenum austenitic stainless steel. J. Shanghai Univ. (Engl. Ed.) 2000, 4, 254-259. [CrossRef]

179. Xu, Y.; Chen, L.; Wang, D.; Jin, L. Flow behavior and evolution of microstructure during hot deformation for a high Mo stainless steel. J. Mater. Sci. Technol. 2000, 16, 341-344. 
180. Kim, S.-I.; Ko, B.-C.; Lee, C.-M.; Hwang, S.-K.; Yoo, Y.-C. Evolution of dynamic recrystallisation in AISI 304 stainless steel. Mater. Sci. Technol. 2003, 19, 1648-1652. [CrossRef]

181. Cho, S.-H.; Kang, K.-B.; Jonas, J.J. The dynamic, static and metadynamic recrystallization of a Nb-microalloyed steel. ISIJ Int. 2001, 41, 63-69. [CrossRef]

182. Cho, S.-H.; Kang, K.-B.; Jonas, J.J. Mathematical modeling of the recrystallization kinetics of Nb microalloyed steels. ISIJ Int. 2001, 41, 766-773. [CrossRef]

183. Imbert, C.A.C.; McQueen, H.J. Peak strength, strain hardening and dynamic restoration of A2 and M2 tool steels in hot deformation. Mater. Sci. Eng. A 2001, 313, 88-103. [CrossRef]

184. Cho, S.-H.; Kim, S.-I.; Yoo, Y.-C. The effects of deformation variables on hot workability of austenitic stainless steel. Met. Mater. Int. 1998, 4, 732-736. [CrossRef]

185. Cho, S.-H.; Yoo, Y.-C. Hot rolling simulations of austenitic stainless steel. J. Mater. Sci. 2001, 36, 4267-4272. [CrossRef]

186. Cho, S.-H.; Yoo, Y.-C. Metadynamic recrystallization of austenitic stainless steel. J. Mater. Sci. 2001, 36, 4279-4284. [CrossRef]

187. Tafzi, K.; Cabrera, J.M.; Prado, J.M. La recristalización dinámica durante la deformación en caliente de un acero calidad ARMCO. Rev. Metal. 2001, 37, 184-189. [CrossRef]

188. Cabrera, J.M.; Prado, J.M. Modelling and simulations in hot deformation of steels. Adv. Tech. Mat. Mat. Proc. J. ATM 2002, 4, 45-57.

189. Cabrera, J.M.; Ponce, J.; Prado, J.M. Modeling thermomechanical processing of austenite. J. Mater. Process. Technol. 2003, 143-144, 403-409. [CrossRef]

190. Cabrera, J.M.; Mejía, I.; Prado, J.M. Effect of rare-earth metals on the hot strength of HSLA steels. Z. Für Met. 2002, 93, 1132-1139. [CrossRef]

191. Vilela, J.J.; Barbosa, R. Prediction of stress-strain curves of hot deformed austenite. ISIJ Int. 2002, 42, 319-321. [CrossRef]

192. Serajzadeh, S.; Taheri, A.K. An investigation on the effect of carbon and silicon on flow behavior of steel. Mater. Des. 2002, 23, 271-276. [CrossRef]

193. Serajzadeh, S.; Mirbagheri, H.; Karimi Taheri, A. Modelling the temperature distribution and microstructural changes during hot rod rolling of a low carbon steel. J. Mater. Process. Technol. 2002, 125, 89-96. [CrossRef]

194. Serajzadeh, S.; Taheri, A.K. Prediction of flow stress at hot working condition. Mech. Res. Commun. 2003, 30,87-93. [CrossRef]

195. Serajzadeh, S. Development of constitutive equations for a high carbon steel using additivity rule. ISIJ Int. 2003, 43, 1050-1055. [CrossRef]

196. Kim, S.-I.; Yoo, Y.-C. Prediction of dynamic recrystallisation behaviour of AISI type 4140 medium carbon steel. Mater. Sci. Technol. 2002, 18, 160-164. [CrossRef]

197. Kim, S.-I.; Lee, Y.; Byon, S.M. Study on constitutive relation of AISI 4140 steel subject to large strain at elevated temperatures. J. Mater. Process. Technol. 2003, 140, 84-89. [CrossRef]

198. Yoo, Y.-C.; Kim, S.-I.; Byon, S.-M.; Lee, Y. Prediction of flow stress and microstructural evolution during hot forging of three microalloyed medium carbon steels. Mater. Sci. Forum 2005, 475, 169-174. [CrossRef]

199. Cho, S.-H.; Kang, K.-B.; Jonas, J.J. Effect of manganese on recrystallisation kinetics of niobium microalloyed steel. Mater. Sci. Technol. 2002, 18, 389-395. [CrossRef]

200. Sun, W.; Lu, C.; Kiet Tieu, A.; Jiang, Z.; Liu, X.; Wang, G. Influence of Nb, V and Ti on peak strain of deformed austenite in Mo-based micro-alloyed steels. J. Mater. Process. Technol. 2002, 125, 72-76. [CrossRef]

201. Jonas, J.J.; Poliak, E.I. The critical strain for dynamic recrystallization in rolling mills. Mater. Sci. Forum 2003, 426-432, 57-66. [CrossRef]

202. Poliak, E.I.; Jonas, J.J. Prediction of interpass softening from the strain hardening rate prior to unloading. ISIJ Int. 2004, 44, 1874-1881. [CrossRef]

203. Uranga, P.; Fernández, A.I.; López, B.; Rodriguez-Ibabe, J.M. Modeling of austenite grain size distribution in $\mathrm{Nb}$ microalloyed steels processed by thin slab casting and direct rolling (TSDR) route. ISIJ Int. 2004, 44, 1416-1425. [CrossRef]

204. El Wahabi, M. Caracterización Termomecánica de Aceros Inoxidables Austeníticos AISI-304. Ph.D. Thesis, Universitat Politècnica de Catalunya, Barcelona, Spain, 2003.

205. Yang, Z.; Wang, R. Formation of ultra-fine grain structure of plain low carbon steel through deformation induced ferrite transformation. ISIJ Int. 2003, 43, 761-766. [CrossRef] 
206. Kim, S.-I.; Lee, Y.; Lee, D.-L.; Yoo, Y.-C. Modeling of AGS and recrystallized fraction of microalloyed medium carbon steel during hot deformation. Mater. Sci. Eng. A 2003, 355, 384-393. [CrossRef]

207. Manohar, P.A.; Lim, K.; Rollett, A.D.; Lee, Y. Computational exploration of microstructural evolution in a medium C-Mn steel and applications to rod mill. ISIJ Int. 2003, 43, 1421-1430. [CrossRef]

208. Jorge, A.M., Jr.; Regone, W.; Balancin, O. Effect of competing hardening and softening mechanisms on the flow stress curve modeling of ultra-low carbon steel at high temperatures. J. Mater. Process. Technol. 2003, 142, 415-421. [CrossRef]

209. Kim, S.-I.; Lee, Y.; Jang, B.-L. Modeling of recrystallization and austenite grain size for AISI 316 stainless steel and its application to hot bar rolling. Mater. Sci. Eng. A 2003, 357, 235-239. [CrossRef]

210. Bang, W.; Lee, C.S.; Chang, Y.W. Finite element analysis of hot forging with flow softening by dynamic recrystallization. J. Mater. Process. Technol. 2003, 134, 153-158. [CrossRef]

211. Puchi-Cabrera, E.S. Simple constitutive relationship for C-Mn steels deformed at elevated temperatures. Mater. Sci. Technol. 2003, 19,715-722. [CrossRef]

212. Zhang, B.; Zhang, H.-B.; Ruan, X.-Y. Dynamic recrystallization behavior of 35CrMo structural steel. J. Cent. South Univ. Technol. 2003, 10, 13-19. [CrossRef]

213. Stumpf, W. Grain size modelling of a low carbon strip steel during hot rolling in a Compact Strip Production (CSP) plant using the Hot Charge Route. J. S. Afr. Inst. Min. Metall. 2003, 103, 617-632.

214. Stewart, G.R. Static and Dynamic Aging and Softening in 304 Stainless Steel. Ph.D. Thesis, McGill University, Montreal, QC, Canada, 2004.

215. Zahiri, S.H.; Byon, S.M.; Kim, S.-I.; Lee, Y.; Hodgson, P.D. Static and metadynamic recrystallization of interstitial free steels during hot deformation. ISIJ Int. 2004, 44, 1918-1923. [CrossRef]

216. Zahiri, S.H.; Hodgson, P.D. The static, dynamic and metadynamic recrystallisation of a medium carbon steel. Mater. Sci. Technol. 2004, 20, 458-464. [CrossRef]

217. Elwazri, A.M.; Wanjara, P.; Yue, S. Critical condition for dynamic recrystallisation of high carbon steels. Mater. Sci. Technol. 2004, 20, 1469-1473. [CrossRef]

218. Stumpf, W. Hot work modelling of two equivalent low carbon strip steels produced, respectively, by the cold charge route and by the hot charge route. J. S. Afr. Inst. Min. Metall. 2004, 104, 643-652.

219. Fernández Sánchez, V. Efecto del contenido de silicio en el comportamiento a fluencia de un acero al carbono. In Final Degree Project; Universitat Politècnica de Catalunya: Barcelona, Spain, 2004.

220. Wang, B.X.; Liu, X.H.; Wang, G.D. Dynamic recrystallization behavior and microstructural evolution in a Mn-Cr gear steel. Mater. Sci. Eng. A 2005, 393, 102-108. [CrossRef]

221. Wang, B.-X.; Xu, X.-D.; Liu, X.-H.; Wang, G.-D. Dynamic Recrystallization Behavior in Mn-Cr Gear Steel. J. Iron Steel Res. Int. 2006, 13, 49-53. [CrossRef]

222. Kim, S.I.; Choi, S.H.; Lee, Y. Influence of phosphorous and boron on dynamic recrystallization and microstructures of hot-rolled interstitial free steel. Mater. Sci. Eng. A 2005, 406, 125-133. [CrossRef]

223. Bianchi, J.H.; Karjalainen, L.P. Modelling of dynamic and metadynamic recrystallisation during bar rolling of a medium carbon spring steel. J. Mater. Process. Technol. 2005, 160, 267-277. [CrossRef]

224. Glowacki, M. The mathematical modelling of thermo-mechanical processing of steel during multi-pass shape rolling. J. Mater. Process. Technol. 2005, 168, 336-343. [CrossRef]

225. Jorge, A.M., Jr.; Balancin, O. Prediction of steel flow stresses under hot working conditions. Mater. Res. 2005, 8, 309-315. [CrossRef]

226. Cartmill, M.R.; Barnett, M.R.; Zahiri, S.H.; Hodgson, P.D. An analysis of the transition between strain dependent and independent softening in austenite. ISIJ Int. 2005, 45, 1903-1908. [CrossRef]

227. Medina, S.F.; Vega, M.I.; Gómez, M.; Gómez, P.P. Influence of the size and volume fraction of TiN particles on hot strength and dynamic recrystallisation in structural steels. ISIJ Int. 2005, 45, 1307-1315. [CrossRef]

228. Lino, R.E.; Barbosa, R. Modeling stress-strain curves of hot deformed Ti-Nb interstitial free austenite. ISIJ Int. 2005, 45, 1758-1760. [CrossRef]

229. Serajzadeh, S. Thermomechanical modelling of hot slab rolling. Mater. Sci. Technol. 2005, 21, 93-102. [CrossRef]

230. Sans Gil, T. Efecto del boro en la deformación en caliente de un acero al carbono. In Final Degree Project; Universitat Politècnica de Catalunya: Barcelona, Spain, 2005.

231. Shafiei, E.; Ebrahimi, R. A modified model to estimate single peak flow stress curves of Ti-IF steel. ISIJ Int. 2012, 52, 569-573. [CrossRef] 
232. Stumpf, W.; Banks, K. The hot working characteristics of a boron bearing and a conventional low carbon steel. Mater. Sci. Eng. A 2006, 418, 86-94. [CrossRef]

233. Zaky, A.I. Determinations of the non-recrystallization temperature for X52 steel produced by compact slab process combined with direct hot rolling. J. Mater. Eng. Perform. 2006, 15, 651-655. [CrossRef]

234. Abbasi, S.M.; Shokuhfar, A. Prediction of hot deformation behaviour of $10 \mathrm{Cr}-10 \mathrm{Ni}-5 \mathrm{Mo}-2 \mathrm{Cu}$ steel. Mater. Lett. 2007, 61, 2523-2526. [CrossRef]

235. Momeni, A.; Shokuhfar, A.; Abbasi, S.M. Dynamic recrystallization of a Cr-Ni-Mo-Cu-Ti-V precipitation hardenable stainless steel. J. Mater. Sci. Technol. 2007, 23, 775-778.

236. Momeni, A.; Abbasi, S.M.; Shokuhfar, A. Hot compression behavior of as-cast precipitation-hardening stainless steel. J. Iron Steel Res. Int. 2007, 14, 66-70. [CrossRef]

237. Zhu, L.-J.; Wu, D.; Zhao, X.-M. Recrystallization Modelling of Hot Deformed Si-Mn TRIP Steel. J. Iron Steel Res. Int. 2007, 14, 61-65. [CrossRef]

238. Ferreira, J.L.; De Melo, T.M.F.; De Bott, I.S.; Santos, D.B.; Rios, P.R. Influence of thermomechanical parameters on the competition between dynamic recrystallization and dynamic strain induced transformation in C-Mn and C-Mn-Nb steels deformed by hot torsion. ISIJ Int. 2007, 47, 1638-1646. [CrossRef]

239. Abbod, M.F.; Sellars, C.M.; Linkens, D.A.; Mahfouf, M.; Cizek, P. Modeling the flow behavior, recrystallization, and crystallographic texture in hot-deformed Fe-30 wt Pct Ni austenite. Metall. Mater. Trans. A 2007, 38, 2400-2409. [CrossRef]

240. Tang, G.-B.; Liu, Z.-D.; Dong, H.; Gan, Y.; Kang, Y.-L.; Li, L.-J.; Mao, X.-P. Numerical simulation of austenite recrystallization in CSP hot rolled C-Mn steel strip. J. Iron Steel Res. Int. 2007, 14, 49-55. [CrossRef]

241. Jafari, M.; Najafizadeh, A.; Rasti, J. Dynamic recrystallization by necklace mechanism durinh hot deformation of 316 stainless steel. Int. J. ISSI 2007, 4, 6-23.

242. Jafari, M.; Najafizadeh, A. Correlation between Zener-Hollomon parameter and necklace DRX during hot deformation of 316 stainless steel. Mater. Sci. Eng. A 2009, 501, 16-25. [CrossRef]

243. Koczurkiewicz, B. The model of prediction of the microstructure austenite C-Mn steel. Arch. Mater. Sci. Eng. 2007, 28, 421-424.

244. Lin, Y.C.; Chen, M.-S.; Zhong, J. Prediction of $42 \mathrm{CrMo}$ steel flow stress at high temperature and strain rate. Mech. Res. Commun. 2008, 35, 142-150. [CrossRef]

245. Lin, Y.C.; Chen, M.-S.; Zhong, J. Numerical simulation for stress/strain distribution and microstructural evolution in 42CrMo steel during hot upsetting process. Comput. Mater. Sci. 2008, 43, 1117-1122. [CrossRef]

246. He, X.; Yu, Z.; Lai, X. A method to predict flow stress considering dynamic recrystallization during hot deformation. Comput. Mater. Sci. 2008, 44, 760-764. [CrossRef]

247. Zhang, Z.-H.; Liu, Y.-N.; Liang, X.-K.; She, Y. The effect of $\mathrm{Nb}$ on recrystallization behavior of a $\mathrm{Nb}$ micro-alloyed steel. Mater. Sci. Eng. A 2008, 474, 254-260. [CrossRef]

248. Wang, B.; Fu, W.; Lv, Z.; Jiang, P.; Zhang, W.; Tian, Y. Study on hot deformation behavior of $12 \% \mathrm{Cr}$ ultra-super-critical rotor steel. Mater. Sci. Eng. A 2008, 487, 108-113. [CrossRef]

249. Arribas, M.; López, B.; Rodriguez-Ibabe, J.M. Additional grain refinement in recrystallization controlled rolling of Ti-microalloyed steels processed by near-net-shape casting technology. Mater. Sci. Eng. A 2008, 485, 383-394. [CrossRef]

250. Ma, L.-Q.; Liu, Z.-Y.; Jiao, S.-H.; Yuan, X.-Q.; Wu, D. Effect of niobium and titanium on dynamic recrystallization behavior of low carbon steels. J. Iron Steel Res. Int. 2008, 15, 31-36. [CrossRef]

251. Abbod, M.F.; Sellars, C.M.; Tanaka, A.; Linkens, D.A.; Mahfouf, M. Effect of changing strain rate on flow stress during hot deformation of Type 316L stainless steel. Mater. Sci. Eng. A 2008, 491, 290-296. [CrossRef]

252. Wang, J.; Chen, J.; Zhao, Z.; Ruan, X.-Y. Dynamic recrystallization behavior of microalloyed forged steel. J. Iron Steel Res. Int. 2008, 15, 78-81. [CrossRef]

253. Kim, N.; Choi, H. The prediction of deformation behavior and interfacial friction under hot working conditions using inverse analysis. J. Mater. Process. Technol. 2008, 208, 211-221. [CrossRef]

254. Mejía, I.; López-Chipres, E.; Maldonado, C.; Bedolla-Jacuinde, A.; Cabrera, J.M. Modeling of the hot deformation behavior of boron microalloyed steels under uniaxial hot-compression conditions. Int. J. Mater. Res. 2008, 99, 1336-1345. [CrossRef] 
255. Dong, L.; Zhong, Y.; Ma, Q.; Yuan, C.; Ma, L. Dynamic recrystallization and grain growth behavior of 20SiMn low carbon alloy steel. Tsinghua Sci. Technol. 2008, 13, 609-613. [CrossRef]

256. Solhjoo, S. Analysis of flow stress up to the peak at hot deformation. Mater. Des. 2009, 30, 3036-3040. [CrossRef]

257. Uranga, P.; Lopez, B.; Rodriguez-Ibabe, J.M. Microalloying and austenite evolution during hot working in near net shape processed steels. Mater. Sci. Technol. 2009, 25, 1147-1153. [CrossRef]

258. Fabík, R.; Kubina, T.; Aksenov, S.; Drozd, K.; Schindler, I.; Kliber, J. Verification of new model for calculation of critical strain for the initialization of dynamic recrystallization using laboratory rolling. Metalurgija 2009, 48, 273-276.

259. Zhang, Y.; Zhang, H.; Wang, G.; Hu, S. Application of mathematical model for microstructure and mechanical property of hot rolled wire rods. Appl. Math. Model. 2009, 33, 1259-1269. [CrossRef]

260. Gao, H.; Xie, Z.; Yu, Y.; Fang, Y.; Wang, J.; Sun, B. Dynamic recrystallization behavior of twin roll cast low carbon steel strip. ISIJ Int. 2009, 49, 546-552. [CrossRef]

261. Zubialde, R.; Uranga, P.; López, B.; Rodriguez-Ibabe, J.M. Dynamic recrystallization of a Nb bearing Al-Si TRIP steel. In Proceedings of the Materials Science \& Technology Conference and Exhibition 2009 MS\&T'09, Pittsburg, PA, USA, 25-29 October 2009; pp. 1369-1380.

262. González, S. Estudio del comportamiento a fluencia en caliente de un acero avanzado de alta resistencia de bajo contenido en carbono NiCrVCu microaleado con boro. In Final Degree Project; Universitat Politècnica de Catalunya: Barcelona, Spain, 2009.

263. Momeni, A.; Dehghani, K. Characterization of hot deformation behavior of 410 martensitic stainless steel using constitutive equations and processing maps. Mater. Sci. Eng. A 2010, 527, 5467-5473. [CrossRef]

264. Mirzadeh, H.; Najafizadeh, A. Extrapolation of flow curves at hot working conditions. Mater. Sci. Eng. A 2010, 527, 1856-1860. [CrossRef]

265. Mirzadeh, H.; Najafizadeh, A.; Moazeny, M. Hot deformation behaviour of precipitation hardening stainless steel. Mater. Sci. Technol. 2010, 26, 501-504. [CrossRef]

266. Mirzadeh, H.; Najafizadeh, A. Flow stress prediction at hot working conditions. Mater. Sci. Eng. A 2010, 527, 1160-1164. [CrossRef]

267. Mirzadeh, H.; Najafizadeh, A. Hot deformation and dynamic recrystallization of 17-4 PH stainless steel. ISIJ Int. 2013, 53, 680-689. [CrossRef]

268. Momeni, A.; Dehghani, K.; Ebrahimi, G.R.; Keshmiri, H. Modeling the flow curve characteristics of 410 martensitic stainless steel under hot working condition. Metall. Mater. Trans. A 2010, 41, 2898-2904. [CrossRef]

269. Momeni, A.; Dehghani, K.; Ebrahimi, G.R. Modeling the initiation of dynamic recrystallization using a dynamic recovery model. J. Alloys Compd. 2011, 509, 9387-9393. [CrossRef]

270. Momeni, A.; Dehghani, K.; Heidari, M.; Vaseghi, M. Modeling the flow curve of AISI 410 martensitic stainless steel. J. Mater. Eng. Perform. 2012, 21, 2238-2243. [CrossRef]

271. Shaban, M.; Eghbali, B. Determination of critical conditions for dynamic recrystallization of a microalloyed steel. Mater. Sci. Eng. A 2010, 527, 4320-4325. [CrossRef]

272. Shaban, M.; Eghbali, B.J. Characterization of austenite dynamic recrystallization under different $Z$ parameters in a microalloyed steel. J. Mater. Sci. Technol. 2011, 27, 359-363. [CrossRef]

273. Jin, Z.; Cui, Z. Investigation on strain dependence of dynamic recrystallization behavior using an inverse analysis method. Mater. Sci. Eng. A 2010, 527, 3111-3119. [CrossRef]

274. Wu, L.-Z.; Li, X.-S.; Chen, J.; Zhang, H.-B.; Cui, Z.-S. Predicting critical conditions and stress-strain curves for dynamic recrystallization in SPHC steel. J. Iron Steel Res. Int. 2010, 17, 51-57. [CrossRef]

275. Lang, Y.-P.; Zhou, Y.; Rong, F.; Chen, H.-T.; Weng, Y.-Q.; Su, J. Hot working of high nitrogen austenitic stainless steel. J. Iron Steel Res. Int. 2010, 17, 45-49. [CrossRef]

276. Niu, T.; Kang, Y.-L.; Gu, H.-W.; Yin, Y.-Q.; Qiao, M.-L.; Jiang, J.-X. Effect of Nb on the dynamic recrystallization behavior of high-grade pipeline steels. Int. J. Miner. Metall. Mater. 2010, 17, 742-747. [CrossRef]

277. Mirzadeh, H.; Cabrera, J.M.; Prado, J.M.; Najafizadeh, A. Hot deformation behavior of a medium carbon microalloyed steel. Mater. Sci. Eng. A 2011, 528, 3876-3882. [CrossRef]

278. Ebrahimi, G.R.; Keshmiri, H.; Momeni, A.; Mazinani, M. Dynamic recrystallization behavior of a superaustenitic stainless steel containing 16\%Cr and 25\%Ni. Mater. Sci. Eng. A 2011, 528, 7488-7493. [CrossRef] 
279. Quan, G.-Z.; Li, G.-S.; Chen, T.; Wang, Y.-X.; Zhang, Y.-W.; Zhou, J. Dynamic recrystallization kinetics of 42CrMo steel during compression at different temperatures and strain rates. Mater. Sci. Eng. A 2011, 528, 4643-4651. [CrossRef]

280. Momeni, A.; Arabi, H.; Rezaei, A.; Badri, H.; Abbasi, S.M. Hot deformation behavior of austenite in HSLA-100 microalloyed steel. Mater. Sci. Eng. A 2011, 528, 2158-2163. [CrossRef]

281. Zeng, Z.; Chen, L.; Zhu, F.; Liu, X. Dynamic recrystallization behavior of a heat-resistant martensitic stainless steel $403 \mathrm{Nb}$ during hot deformation. J. Mater. Sci. Technol. 2011, 27, 913-919. [CrossRef]

282. Li, D.; Feng, Y.; Yin, Z.; Shangguan, F.; Wang, K.; Liu, Q.; Hu, F. Prediction of hot deformation behaviour of Fe-25Mn-3Si-3Al TWIP steel. Mater. Sci. Eng. A 2011, 528, 8084-8089. [CrossRef]

283. Bao, S.; Zhao, G.; Yu, C.; Chang, Q.; Ye, C.; Mao, X. Recrystallization behavior of a Nb-microalloyed steel during hot compression. Appl. Math. Model. 2011, 35, 3268-3275. [CrossRef]

284. Xiong, W.; Wietbrock, B.; Saeed-Akbari, A.; Bambach, M.; Hirt, G. Modeling the flow behavior of a high-manganese steel Fe-Mn23-C0.6 in consideration of dynamic recrystallization. Steel Res. Int. 2011, 82, 127-136. [CrossRef]

285. Mejía, I.; Bedolla-Jacuinde, A.; Maldonado, C.; Cabrera, J.M. Determination of the critical conditions for the initiation of dynamic recrystallization in boron microalloyed steels. Mater. Sci. Eng. A 2011, 528, 4133-4140. [CrossRef]

286. Sajadifar, S.V.; Ketabchi, M.; Nourani, M. Modeling of mechanical characteristics in hot deformation of 4130 steel. Steel Res. Int. 2011, 82, 934-939. [CrossRef]

287. Sun, M.; Hao, L.; Li, S.; Li, D.; Li, Y. Modeling flow stress constitutive behavior of SA508-3 steel for nuclear reactor pressure vessels. J. Nucl. Mater. 2011, 418, 269-280. [CrossRef]

288. Wu, H.; Du, L.; Liu, X. Dynamic recrystallization and precipitation behavior of $\mathrm{Mn}-\mathrm{Cu}-\mathrm{V}$ weathering steel. J. Mater. Sci. Technol. 2011, 27, 1131-1138. [CrossRef]

289. Shi, R.-X.; Liu, Z.-D. Hot deformation behavior of P92 steel used for ultra-super-critical power plants. J. Iron Steel Res. Int. 2011, 18, 53-58. [CrossRef]

290. Jia, B.; Peng, Y. Constitutive relationships of $\mathrm{Nb}$ microalloyed steel during high temperature deformation. Acta Metall. Sin. 2011, 4, 507-512.

291. Chen, M.-S.; Lin, Y.C.; Ma, X.-S. The kinetics of dynamic recrystallization of 42 CrMo steel. Mater. Sci. Eng. A 2012, 556, 260-266. [CrossRef]

292. Xu, Y.; Tang, D.; Song, Y.; Pan, X. Dynamic recrystallization kinetics model of X70 pipeline steel. Mater. Des. 2012, 39, 168-174. [CrossRef]

293. Mirzaee, M.; Keshmiri, H.; Ebrahimi, G.R.; Momeni, A. Dynamic recrystallization and precipitation in low carbon low alloy steel 26NiCrMoV 14-5. Mater. Sci. Eng. A 2012, 551, 25-31. [CrossRef]

294. Wang, J.; Xiao, H.; Xie, H.; Xu, X.; Gao, Y. Study on hot deformation behavior of carbon structural steel with flow stress. Mater. Sci. Eng. A 2012, 539, 294-300. [CrossRef]

295. Ebrahimi, G.R.; Keshmiri, H.; Maldar, A.R.; Momeni, A. Dynamic recrystallization behavior of $13 \% \mathrm{Cr}$ martensitic stainless steel under hot working condition. J. Mater. Sci. Technol. 2012, 28, 467-473. [CrossRef]

296. Shafiei, E.; Ebrahimi, R. A new constitutive equation to predict single peak flow stress curves. J. Eng. Mater. Technol. Trans. ASME 2013, 135, 011006. [CrossRef]

297. Liu, P.; Liu, R.; Wei, Y.; Yang, H.; Yong, Q.; Bao, Y. Austenite dynamic recrystallization of the microalloyed forging steels 38MnVS during forging process. Procedia Eng. 2012, 27, 63-71. [CrossRef]

298. Zhang, T.-B.; Shen, Y.; Liu, P.; Yong, Q.-L.; Bao, Y.-Z. New type austenite dynamic recrystallization of microalloyed forging steels 38MnVS during forging process. J. Iron Steel Res. Int. 2013, 20, 57-60. [CrossRef]

299. Badjena, S.K.; Park, J.K. Effect of particles on the dynamic recrystallization behavior of Al-V-N micro-alloyed medium carbon steel. Mater. Sci. Eng. A 2012, 548, 126-133. [CrossRef]

300. Liang, G.; Lin, C.; Fang, Y. Flow stress and critical dynamic recrystallization behavior of Cu-Fe16Mn0.6C high manganese TWIP steel. Steel Res. Int. 2012, 83, 328-333.

301. Cao, J.-R.; Liu, Z.-D.; Cheng, S.-C.; Yang, G.; Xie, J.-X. Constitutive equation models of hot-compressed T122 heat resistant steel. J. Iron Steel Res. Int. 2012, 19, 53-58. [CrossRef]

302. Han, Y.; Liu, G.; Zou, D.; Liu, R.; Qiao, G. Deformation behavior and microstructural evolution of as-cast 904L austenitic stainless steel during hot compression. Mater. Sci. Eng. A 2013, 565, 342-350. [CrossRef] 
303. Wei, H.-L.; Liu, G.-Q.; Zhao, H.-T.; Kang, R.-M. Hot deformation behavior of two C-Mn-Si based and C-Mn-Al based microalloyed high-strength steels: A comparative study. Mater. Des. 2013, 50, 484-490. [CrossRef]

304. Wei, H.-L.; Liu, G.-Q.; Xiao, X.; Zhao, H.-T.; Ding, H.; Kang, R.-M. Characterization of hot deformation behavior of a new microalloyed C-Mn-Al high-strength steel. Mater. Sci. Eng. A 2013, 564, 140-146. [CrossRef]

305. Liu, Y.G.; Li, M.Q.; Luo, J. The modelling of dynamic recrystallization in the isothermal compression of 300M steel. Mater. Sci. Eng. A 2013, 574, 1-8. [CrossRef]

306. Mirzadeh, H.; Parsa, M.H.; Ohadi, D. Hot deformation behavior of austenitic stainless steel for a wide range of initial grain size. Mater. Sci. Eng. A 2013, 569, 54-60. [CrossRef]

307. Yan, T.; Yu, E.; Zhao, Y. Constitutive modeling for flow stress of 55SiMnMo bainite steel at hot working conditions. Mater. Des. 2013, 50, 574-580. [CrossRef]

308. Wei, H.-L.; Liu, G.-Q.; Xiao, X.; Zhang, M.-H. Dynamic recrystallization behavior of a medium carbon vanadium microalloyed steel. Mater. Sci. Eng. A 2013, 573, 215-221. [CrossRef]

309. Momeni, A.; Dehghani, K.; Poletti, M.C. Law of mixture used to model the flow behavior of a duplex stainless steel at high temperatures. Mater. Chem. Phys. 2013, 139, 747-755. [CrossRef]

310. Li, X.; Wu, X.-C.; Zhang, X.-X.; Li, M.-Y. Dynamic recrystallization of hot deformed 3Cr2NiMnMo steel: Modeling and numerical simulation. J. Iron Steel Res. Int. 2013, 20, 98-104. [CrossRef]

311. Schambron, T.; Chen, L.; Gooch, T.; Dehghan-Manshadi, A.; Pereloma, E.V. Effect of Mo concentration on dynamic recrystallization behavior of low carbon microalloyed steels. Steel Res. Int. 2013, 84, 1191-1195. [CrossRef]

312. Rakhshkhorshid, M.; Hashemi, S.H. Experimental study of hot deformation behavior in API X65 steel. Mater. Sci. Eng. A 2013, 573, 37-44. [CrossRef]

313. Lei, X.-R.; Ding, Q.-F.; Chen, Y.-Y.; Rui, X.-L.; Li, S.-R.; Wang, Q.-F. Effect of niobium on dynamic recrystallization behavior of 5\%Ni steel. J. Iron Steel Res. Int. 2013, 20, 38-44. [CrossRef]

314. Yazdani, M.; Abbasi, S.M.; Taheri, A.K.; Momeni, A. Hot deformation behavior of Fe-29Ni-17Co alloy. Trans. Nonferrous Met. Soc. China 2013, 23, 3271-3279. [CrossRef]

315. Yan, P.; Liu, Z.-D.; Liu, W.; Bao, H.-S.; Weng, Y.-Q. Hot deformation behavior of a new 9\% Cr heat resistant steel G115. J. Iron Steel Res. Int. 2013, 20, 73-79. [CrossRef]

316. Yan, T.; Yu, E.-L.; Zhao, Y.-Q. Modeling of hot deformation behavior of 55SiMnMo medium-carbon steel. J. Iron Steel Res. Int. 2013, 20, 125-130. [CrossRef]

317. Uranga, P.; Gutiérrez, I.; López, B. Determination of recrystallization kinetics from plane strain compression tests. Mater. Sci. Eng. A 2013, 578, 174-180. [CrossRef]

318. Al Shahrani, A.; Yazdipour, N.; Dehghan-Manshadi, A.; Gazder, A.A.; Cayron, C.; Pereloma, E.V. The effect of processing parameters on the dynamic recrystallisation behaviour of API-X70 pipeline steel. Mater. Sci. Eng. A 2013, 570, 70-81. [CrossRef]

319. Gao, X.; Zhu, M.; Sun, C.; Fu, G. Dynamic recrystallization behavior and microstructure evolution of bridge weathering steel in austenite region. Steel Res. Int. 2013, 84, 377-386. [CrossRef]

320. Peng, N.-Q.; Tang, G.-B.; Yao, J.; Liu, Z.-D. Hot deformation behavior of GCr15 steel. J. Iron Steel Res. Int. 2013, 20, 50-56. [CrossRef]

321. Gu, S.-D.; Zhang, L.-W.; Ruan, J.-H.; Zhou, P.-Z.; Zhen, Y. Constitutive modeling of dynamic recrystallization behavior and processing map of 38MnVS6 non-quenched steel. J. Mater. Eng. Perform. 2013, 23, 1062-1068. [CrossRef]

322. Zhang, W.-F.; Li, X.-L.; Sha, W.; Yan, W.; Wang, W.; Shan, Y.-Y.; Yang, K. Hot deformation characteristics of a nitride strengthened martensitic heat resistant steel. Mater. Sci. Eng. A 2014, 590, 199-208. [CrossRef]

323. Zhao, B.; Zhao, T.; Li, G.; Lu, Q. The kinetics of dynamic recrystallization of a low carbon vanadium-nitride microalloyed steel. Mater. Sci. Eng. A 2014, 604, 117-121. [CrossRef]

324. Nkhoma, R.K.C.; Siyasiya, C.W.; Stumpf, W.E. Hot workability of AISI 321 and AISI 304 austenitic stainless steels. J. Alloys Compd. 2014, 595, 103-112. [CrossRef]

325. Wei, H.-L.; Liu, G.-Q.; Zhao, H.-T.; Zhang, M.-H. Effect of carbon content on hot deformation behaviors of vanadium microalloyed steels. Mater. Sci. Eng. A 2014, 596, 112-120. [CrossRef] 
326. Wei, H.-L.; Liu, G.-Q. Effect of $\mathrm{Nb}$ and $\mathrm{C}$ on the hot flow behavior of $\mathrm{Nb}$ microalloyed steels. Mater. Des. 2014, 56, 437-444. [CrossRef]

327. Samantaray, D.; Mandal, S.; Jayalakshmi, M.; Athreya, C.N.; Bhaduri, A.K.; Subramanya Sarma, V. New insights into the relationship between dynamic softening phenomena and efficiency of hot working domains of a nitrogen enhanced 316L(N) stainless steel. Mater. Sci. Eng. A 2014, 598, 368-375. [CrossRef]

328. Naghdy, S.; Akbarzadeh, A. Characterization of dynamic recrystallization parameters for a low carbon resulfurized free-cutting steel. Mater. Des. 2014, 53, 910-914. [CrossRef]

329. Sha, Q.-Y.; Li, D.-H.; Li, G.-Y. Dynamic and static recrystalization behaviour of coarse-grained austenite in a $\mathrm{Nb}-\mathrm{V}-\mathrm{Ti}$ microaloyed steel. J. Iron Steel Res. Int. 2014, 21, 233-239. [CrossRef]

330. Timoshenkov, A.; Warczok, P.; Albu, M.; Klarner, J.; Kozeschnik, E.; Bureau, R.; Sommitsch, C. Modelling the dynamic recrystallization in C-Mn micro-alloyed steel during thermo-mechanical treatment using cellular automata. Comput. Mater. Sci. 2014, 94, 85-94. [CrossRef]

331. Marandi, A.; Zarei-Hanzaki, R.; Zarei-Hanzaki, A.; Abedi, H.R. Dynamic recrystallization behavior of new transformation-twinning induced plasticity steel. Mater. Sci. Eng. A 2014, 607, 397-408. [CrossRef]

332. Ferdowsi, M.R.G.; Nakhaie, D.; Benhangi, P.H.; Ebrahimi, G.R. Modeling the high temperature flow behavior and dynamic recrystallization kinetics of a medium carbon microalloyed steel. J. Mater. Eng. Perform. 2013, 23, 1077-1087. [CrossRef]

333. Badjena, S.K. Dynamic recrystallization behavior of vanadium micro-alloyed forging medium carbon steel. ISIJ Int. 2014, 54, 650-656. [CrossRef]

334. Fu, Y.; Yu, H. Application of mathematical modeling in two-stage rolling of hot rolled wire rods. J. Mater. Process. Technol. 2014, 214, 1962-1970. [CrossRef]

335. Chen, F.; Ren, F.-C.; Cui, Z.-S.; Lai, X.-M. Constitutive modeling for elevated temperature flow behavior of 30Cr2Ni4MoV ultra-super-crical rotor steel. J. Iron Steel Res. Int. 2014, 21, 521-526. [CrossRef]

336. Zou, D.N.; Liu, R.; Han, Y.; Zhang, W.; Wu, K.; Liu, X.H. On dynamic recrystallisation under hot working of superaustenitic stainless steel. Mater. Sci. Technol. 2014, 30, 411-417. [CrossRef]

337. Mejía, I.; Altamirano, G.; Bedolla-Jacuinde, A.; Cabrera, J.M. Modeling of the hot flow behavior of advanced ultra-high strength steels (A-UHSS) microalloyed with boron. Mater. Sci. Eng. A 2014, 610, 116-125. [CrossRef]

338. Dupin, E.; Yanagida, A.; Yanagimoto, J. Modeling static and dynamic kinetics of microstructure evolution in type 316 stainless steel. Steel Res. Int. 2014, 85, 1099-1108. [CrossRef]

339. Zhao, X.; Zhang, J.; Lei, S.; Wang, Y. Dynamic recrystallization (DRX) analysis of heavy reduction process with extra-thickness slabs. Steel Res. Int. 2014, 85, 811-823. [CrossRef]

340. Ma, L.-T.; Wang, L.-M.; Liu, Z.-D.; Yang, G.; Lu, L.; Peng, M.-D. Hot deformation behavior of F6NM stainless steel. J. Iron Steel Res. Int. 2014, 21, 1035-1041. [CrossRef]

341. Zhang, D.; Liu, Y.-Z.; Zhou, L.-Y.; Han, Q.; Jiang, B.; Li, Z.-Z. Dynamic recrystallization behavior of GCr15SiMn bearing steel during hot deformation. J. Iron Steel Res. Int. 2014, 21, 1042-1048. [CrossRef]

342. Sui, D.-S.; Chen, F.; Zhang, P.-P.; Cui, Z.-S. Numerical simulation of microstructure evolution for SA508-3 steel during inhomogeneous hot deformation process. J. Iron Steel Res. Int. 2014, 21, 1022-1029. [CrossRef]

343. Wang, J.; Yang, H.T.; Wang, X.G.; Xiao, H. A new mathematical model for predicting flow stress up to the critical strain during hot deformation. Mater. Des. 2015, 65, 637-643. [CrossRef]

344. Momeni, A.; Abbasi, S.M. On the opposition of dynamic recrystallization and solute dragging in steels. J. Alloys Compd. 2015, 622, 318-326. [CrossRef]

345. Li, X.; Duan, L.; Li, J.; Wu, X. Experimental study and numerical simulation of dynamic recrystallization behavior of a micro-alloyed plastic mold steel. Mater. Des. 2015, 66, 309-320. [CrossRef]

346. Han, Y.; Wu, H.; Zhang, W.; Zou, D.; Liu, G.; Qiao, G. Constitutive equation and dynamic recrystallization behavior of as-cast 254SMO super-austenitic stainless steel. Mater. Des. 2015, 69, 230-240. [CrossRef]

347. Dong, D.; Chen, F.; Cui, Z. A physically-based constitutive model for SA508-III steel: Modeling and experimental verification. Mater. Sci. Eng. A 2015, 634, 103-115. [CrossRef]

348. Zhu, S.-L.; Cao, H.-Z.; Ye, J.-S.; Hu, W.-H.; Zheng, G.-Q. Dynamic recrystallization behavior of medium carbon Cr-Ni-Mo-Nb steel during hot deformation. J. Iron Steel Res. Int. 2015, 22, 264-271. [CrossRef] 
349. Saadatkia, S.; Mirzadeh, H.; Cabrera, J.M. Hot deformation behavior, dynamic recrystallization, and physically-based constitutive modeling of plain carbon steels. Mater. Sci. Eng. A 2015, 636, 196-202. [CrossRef]

350. Li, L.; Ye, B.; Liu, S.; Hu, S.; Li, B. Inverse analysis of the stress-strain curve to determine the materials models of work hardening and dynamic recovery. Mater. Sci. Eng. A 2015, 636, 243-248. [CrossRef]

(C) 2020 by the authors. Licensee MDPI, Basel, Switzerland. This article is an open access article distributed under the terms and conditions of the Creative Commons Attribution (CC BY) license (http://creativecommons.org/licenses/by/4.0/). 